\title{
Comparing the Impacts of Financial Regulation in Australia and the United States via Simulation with Country-specific Financial CGE Models
}

\section{CoPS Working Paper No. G-263, August 2016}

\section{J. Nassios,}

James A. Giesecke, Maureen T. Rimmer,

\section{Peter B. Dixon}

Centre of Policy Studies, Victoria University 


\title{
Comparing the impacts of financial regulation in Australia and the United States via simulation with country-specific financial CGE models
}

\author{
J. Nassios* ${ }^{1}$, James A. Giesecke ${ }^{2}$, P. B. Dixon ${ }^{3}$, M. T. Rimmer ${ }^{4}$
}

\begin{abstract}
Beginning with Johansen (1960), computable general equilibrium (CGE) models have been widely applied to study the impact of a variety of economic issues of interest to policy makers. These include changes in taxes and tariffs, changes in labour force demographics and skill levels, the impact of epidemics and terrorist attacks, the impact of drought and water policy reform, and the economic costs of climate change mitigation (Dixon and Parmenter (1996); Dixon and Rimmer (2002); Adams (2007); Giesecke et al. (2015); Wittwer and Dixon (2015)). Despite the efficacy of CGE models as tools in policy analysis, key linkages between the real and financial economies are often treated implicitly; for example, the current account deficit is assumed to be financed in full by a foreign agent, e.g., via a small country assumption. In an explicit sense we may ask how the foreign investor chooses to finance a deficit, e.g., do they prefer to purchase domestic agent bonds, equity or a combination of the two instruments? What are the associated implications for relative rates-ofreturn across the suite of domestic financial instruments, and how do changes in relative returns affect domestic agent investment decisions, nominal exchange rates, and the real economy? This paper seeks to address such questions via the development of a theory of the financial sector for a traditional dynamic CGE model of the U.S. (USAGE 2.0). We begin with a brief synopsis of the construction of a financial database for the United States (U.S.), which documents the stocks and transactional flows of 5 financial instruments across 11 distinct agents. The financial database derived herein and the approach documented in Dixon et al. (2015), are then used to develop a new financial CGE model of the U.S. called USAGE2F. Explicit recognition of financial stocks and flows broadens the scope of CGE analyses to include the effects of changes in capital adequacy requirements of key financial agents, e.g., the commercial banks, as we illustrate with an example. The results are subsequently compared to findings of a similar policy scenario in Australia, which are outlined in Giesecke et al. (2016). This analysis serves to illustrate how the impacts of regulatory change (in this case, a rise in capital adequacy ratios) can be affected by jurisdiction-specific differences in the structure of the financial sector.
\end{abstract}

JEL classification: E17, E44, G21, C68

Keywords: Capital adequacy ratio, financial stability, financial CGE model

* Corresponding author.

1.Centre of Policy Studies,

Victoria University.

E-mail: Jason.Nassios@vu.edu.au

Ph: +61 399191480

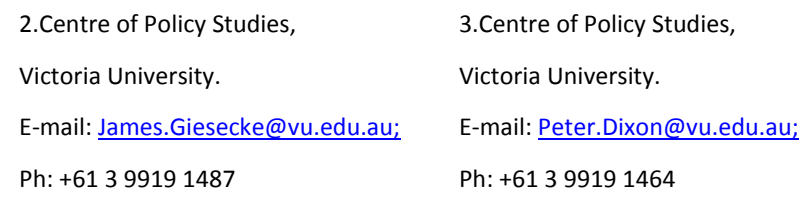




\section{Table of Contents}

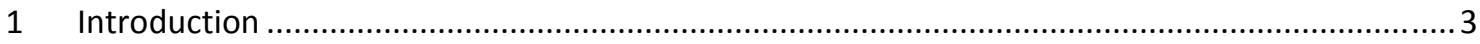

2 The USAGE2F financial computable general equilibrium (FCGE) model .................................... 5

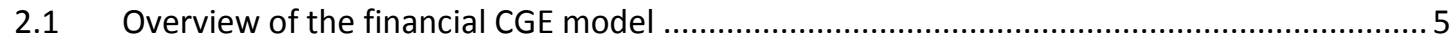

2.2 Monetary and regulatory transmission mechanism in the FCGE model ............................... 8

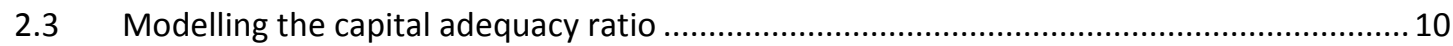

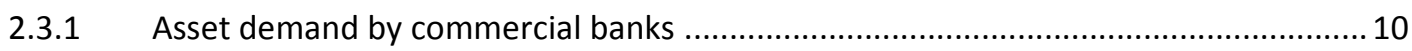

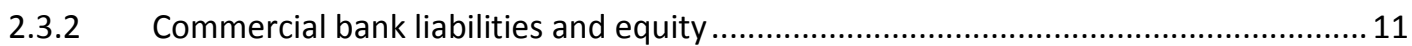

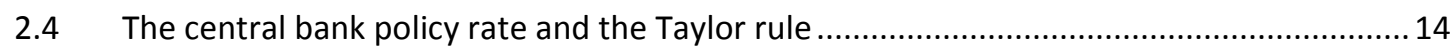

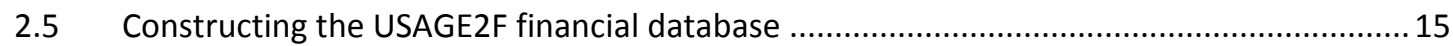

2.5.1 A description of the Board of Governors of The Federal Reserve System Statistical

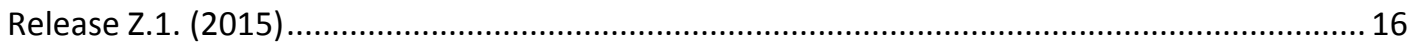

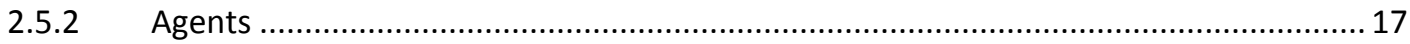

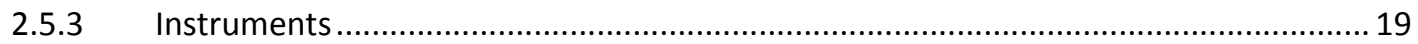

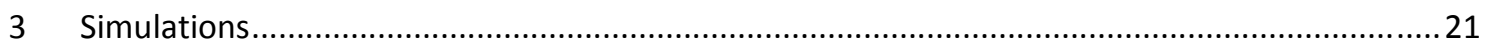

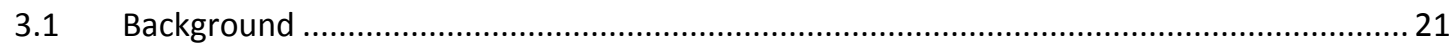

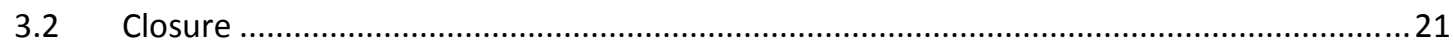

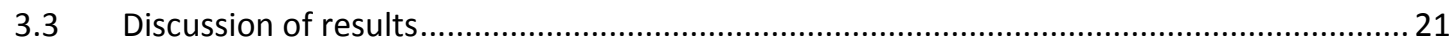

3.4 The macroeconomic impacts of financial structure differences: Comparing the impacts of

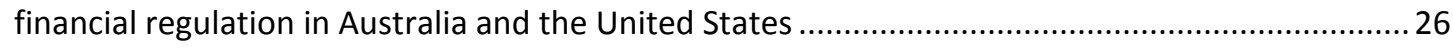

3.4.1 Key structural differences between the United States and Australia...........................2 27

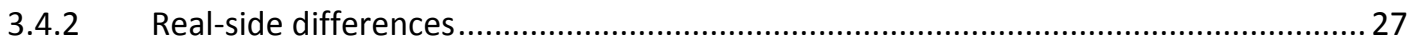

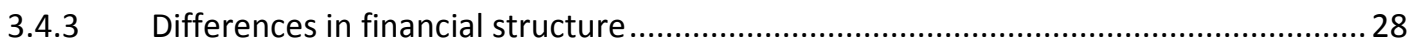

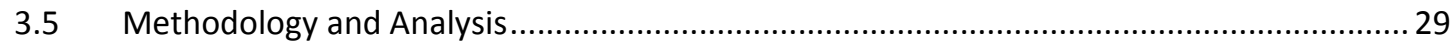

3.5.1 Decomposing the differences between Australia and the United States......................30

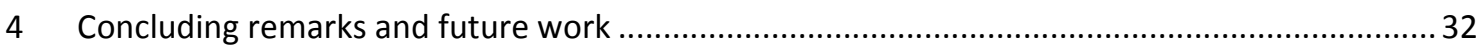

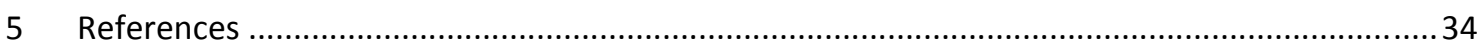

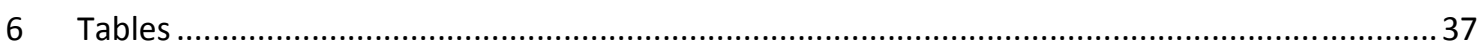

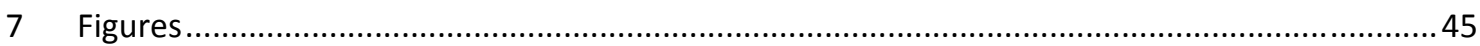




\section{Introduction}

The USAGE 2.0 model is a dynamic computable general equilibrium (CGE) model of the United States based on the MONASH model Dixon and Rimmer (2002), and developed in collaboration with the U.S. International Trade Commission. USAGE 2.0 and its predecessor (USAGE) have been widely applied to study the effects on macro, industry, regional, occupational and environmental variables, of changes in tariffs, taxes, commodity prices, technologies, public expenditures, environmental policies, labour-market conditions, and regulations affecting capital inflows/outflows; see for example Dixon and Rimmer (2004), Dixon and Rimmer (2009) and Dixon et al. (2011).

The foundations of the USAGE 2.0 model are couched in the various optimising decisions faced by industries, households, governments, exporters and importers. The equations that result from the solution of these optimisation problems determine each agent's unique demands and supplies of goods and factors. Prices are then quantified by the interaction of demand and supply in commodity and factor markets, thus providing a comprehensive treatment of the interaction of the agents that drive the real-side of the U.S. economy.

However, the USAGE 2.0 model does not include an explicit treatment of the various U.S. financial intermediaries, e.g., the Central Bank, or the agents they interact with, e.g., the commercial banks and non-bank financial institutions such as the Government Sponsored Entities (GSE's). The model is also silent on various links between the real- and monetary-sides of the U.S. economy. These limitations preclude the study of important policy questions related to the financial sector. For example, we cannot endogenously quantify the impact of a change in monetary policy in the U.S. on variables such as investment using USAGE 2.0, without first estimating impacts on key exogenous variables (like required rates of return) outside of the model.

To facilitate the analysis of a broader range of policy issues, in section 2 of this report we describe the development of USAGE2F, a financial CGE model of the U.S. economy. We follow a similar approach to the one outlined in Dixon et al. (2015). This specifies agent-specific supplies and demands for financial instruments in the U.S., and carries equations that describe how various financial agents choose to finance their activities, e.g., how much of domestic investment by industries is financed by issuing debt and/or equity, and how does the debt/equity mix vary in response to changing relative rates of return? In addition, USAGE2F includes demand-side equations that describe how the various financial agents, in their capacity as asset owners (or asset agents) in holding these financial liabilities, decide where to allocate their finite capital resources.

Our development of USAGE2F is motivated by several important distinctions that exist between the Australian and U.S. financial markets. For example, in the U.S. various GSE's, e.g., Fannie Mae, act as market-makers by purchasing loans originated by commercial banks, e.g., Fannie 
Mae purchases home loans. These loans would otherwise persist as assets on the balance sheets of U.S. commercial banks. In contrast, Australian commercial bank balance sheets are dominated by housing loans relative to their global counterparts, as noted in the recent Financial System Inquiry (see Commonwealth of Australia (2014)). This is driven in-part by a general lack of liquidity in the Australian mortgage-backed security market post-GFC, which was supported from 2008 to 2013 via direct market participation by the Australian Office of Financial Management. ${ }^{1}$

With regard to the exposure of U.S. commercial banks to residential property loans, the Board of Governors of The Federal Reserve System Statistical Release Z.1. (2015) shows that 28 per cent of outstanding U.S. home loan liabilities in 2013 were held as financial assets of the U.S. commercial banks. Almost double this proportion (46 per cent) were assets of the GSE's. This contrasts with our findings for Australia ${ }^{2}$, where in excess of 75 per cent of Australian household loans (both short- and long-term) were assets of Australian commercial banks at the end of 2013. All else being equal, this necessitates a larger equity-to-deposit ratio for Australian banks relative to their U.S. counterparts, in order to satisfy bank capital adequacy requirements.

How do structural differences such as these alter the macro- and industry-level impacts of changes in policy between Australia and the U.S? We explore this question herein, by comparing the macro- and industry-level impacts of heightened bank capital adequacy regulations in the U.S. and Australia. We model the capital adequacy ratio and its impact on the behaviour of the commercial banks in the U.S, using a similar approach to that adopted for the Australian economy by Giesecke et al. (2016).

As we outline in section 3, this is achieved by developing two business-as-usual (BAU) baselines for USAGE2F, with capital adequacy constraints on commercial bank behaviour in place that mirror those in Giesecke et al. (2016). In the first baseline (BAU1), the capital adequacy ratio and risk weights are set at business-as-usual levels. In the second baseline (BAU2), the capital adequacy ratio and risk weights are set at levels reflective of a more conservative stance by the prudential regulator. The results of these two simulations in USAGE2F facilitate two analyses, discussed in 3.3 herein. First, we explore the costs of financial regulation in the U.S. by analysing the differences in outcomes for important policy variables (e.g., real GDP, employment, consumption, investment) in BAU2 relative to BAU1. Next, with the regulatory framework adopted under BAU1 and BAU2 in USAGE2F similar to those used to study the impact of financial regulation in Australia by Giesecke et al. (2016), we compare our findings with those in Giesecke et al. (2016) for Australia. This allows us to decompose differences in the macroeconomic implications of changes in the capital adequacy of domestic commercial banks into two parts: (1) variations driven by dissimilarities in the real economies of each nation; and (2) differences in their respective financial structures. The relative importance of these differences is then explored, with our findings summarised in section 3.5.1.

${ }^{1}$ See http://www.apra.gov.au/Policy/Documents/September-2012-Basel-III-capital-regulation-impactstatement.pdf and http://aofm.gov.au/cash-management-and-investments/residential-mortgage-backedsecurities/

${ }^{2}$ Data sourced from the ABS 5232.0 - Australian National Accounts: Finance and Wealth, September 2015. See http://www.abs.gov.au/AUSSTATS/abs@.nsf/DetailsPage/5232.0Sep\%202015?OpenDocument 
We conclude with some remarks and directions for future work in section 4, whilst references, tables and figures are reported in sections 5, 6, and 7 respectively.

\section{The USAGE2F financial computable general equilibrium (FCGE) model}

In this section we provide a summary of the USAGE2F model used in the simulations described in Section 3. For a detailed discussion of the financial part of the USAGE2F model, we refer the reader to Dixon et al. (2015) and Giesecke et al. (2016). As we shall describe, the FCGE model is based on identification of many agents and the optimising behaviour governing their actions. From this framework emerge a number of transmission mechanisms via which a change in commercial bank capital requirements can affect activity in the real economy. We go on to describe the developments to the FCGE model that are specific to the simulations describing a rise in capital adequacy ratios.

\subsection{Overview of the financial CGE model}

While fully integrated, the USAGE2F model can nevertheless be broadly considered as being comprised of two parts:

(i) A traditional CGE model describing the real-side of the economy, based upon the

USAGE 2.0 CGE model of the U.S. economy; and

(ii) A model of the interactions between financial agents and their links with the real side of the economy.

We expand on these two parts, and the important links between them, below.

As discussed, the real-side of the USAGE2F model is based upon the USAGE 2.0 model. USAGE 2.0 is a dynamic CGE model of the U.S. economy based on the MONASH model, and developed in collaboration with the U.S. International Trade Commission. For a detailed description of the economic mechanisms in USAGE 2.0 and other models following the MONASH framework, we refer the reader to Dixon and Rimmer (2002). In what follows, we provide an overview of the real-side model for USAGE2F, which pertains to a description of the key features of the USAGE 2.0 model.

USAGE 2.0 is a disaggregated CGE model recognising many industries, capital creators, a representative household, government, and a foreign sector. Industries, investors and households are modelled as constrained optimizers. Each industry minimizes unit costs subject to given input prices and a constant-returns-to-scale (CRS) production function. Consumer demands are modelled via a representative utility maximizing household. Units of new industry-specific capital are formed as cost minimizing combinations of construction, machinery, engineering services, and other inputs relevant to physical capital formation. Imperfect substitutability between imported and domestic varieties of each commodity is 
modelled using the Armington constant-elasticity-of-substitution (CES) specification. Export demand for any given U.S. commodity is inversely related to its foreign currency price. Physical capital accumulation is specified separately for each industry. An industry's capital stock at the start of year $t+1$ is its capital at the start of year $t$ plus its investment during year $t$, less depreciation. Industry-specific investment in year $t$ is determined as a positive function of the expected rate of return on industry-specific capital.

Movements in relative prices reconcile the demand and supply sides of most commodity and factor markets through market clearing conditions. An important exception is the labour market, which is assumed to experience sticky wages in the short-run, but transition in the long-run to an environment of wage flexibility and a given natural rate of unemployment. Zero pure profit conditions in current production and capital formation determine basic prices (prices at the factory door) for domestically produced output. Purchases prices differ from basic prices by the value of margin services and indirect taxes. In addition to indirect taxes, government revenue from direct taxes is identified, as are a variety of government outlays beyond public consumption spending (such as personal benefit payments and public investment). Together with variables describing foreign transfer payments, this provides sufficient detail for the identification of the government borrowing requirement, household disposable income, and household savings. Margin services, e.g., trade, transport, insurance and other margins, are also explicitly recognised as commodity flow facilitators between various agents, such as producers, importers, households, government, investors and foreign agents in export markets

Real-side CGE models with characteristics such as those described above have been used for many decades to answer diverse policy questions Dixon and Rimmer (2016). They are however silent on, or treat implicitly, the question of how a number of important transactions are financed. For example, how is investment spending financed? How does the cost of financial capital affect the decision to invest in physical capital? Who is financing the public sector borrowing requirement (PSBR)? How is the current account deficit financed? Who decides on how household savings are allocated? An important role of the financial part of the FCGE model is to answer these and related questions.

The financial part of the USAGE2F model identifies 5 financial instruments and 11 financial agents. ${ }^{3}$ Each financial agent is concerned with both the asset and the liability/equity sides of its balance sheet. Hereafter, we refer to financial agents as "asset agents" in matters concerned with the asset sides of their balances sheets, and as "liability agents" in matters concerned with the liability and equity sides of their balance sheets. The core of the FCGE model is three arrays and the equations describing how the values in these arrays change through time. The three arrays are:

\footnotetext{
${ }^{3}$ The financial instruments are: Cash, Deposits/loans, Bonds, Equity, Gold and SDRs. The financial agents are: Commercial banks, the Central Bank, Foreigners, Government, Households, Industries, NBFIs, Superannuation, Life insurance, Non-reproducible housing, Reproducible housing. We divide the housing sector into "reproducible" and "non-reproducible" housing in anticipation of future model applications, e.g., the simulation of property price bubbles. For non-reproducible housing (established inner-city dwellings) it is conceivable that asset prices can depart from construction costs. For reproducible housing (apartments, units, and houses outside the inner city) construction costs should anchor asset prices.
} 
$\mathrm{A}_{(\mathrm{s}, \mathrm{f}, \mathrm{d})} \quad$ which describes the holdings by asset agent $d$ (e.g. households, the banking sector) of financial instrument $f$ (e.g. equity, loans, bonds) issued by liability agent $s$ (e.g. households, government, industry).

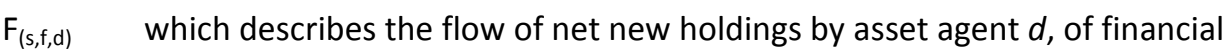
instrument $f$, issued by liability agent $s$.

$R_{(s, f, d)} \quad$ which describes the power of the rate of return (i.e. one plus the rate) on financial instrument $f$, issued by liability agent $s$, and held as an asset by agent $d$.

Financial agents are assumed to be constrained optimisers. Broadly, in their capacity as liability agents, financial agents are assumed to issue the mix of financial instruments that minimises the cost of servicing the total liabilities they require, subject to a constraint that prevents them moving to corner solutions in the issuance of particular financial instruments to particular asset agents. Similarly, in their capacity as asset agents, financial agents are assumed to hold the mix of financial instruments that maximises the return from their portfolio of financial assets, subject to a constraint that prevents them moving to corner solutions in the holding of particular financial instruments issued by particular liability agents. The solutions to these optimisation problems are a set of return-sensitive supply equations (governing the issuance of financial instruments by liability agents) and return-sensitive demand equations (governing the demand for financial instruments by asset agents). In general, the solution to these supply and demand equations determines rates of return across financial instruments $(R(s, f, d))$.

Results from the real-side of the FCGE model (while determined endogenously with the financial side) can be viewed as providing important constraints on the financial side of the model. Similarly, results for certain variables in the financial side of the FCGE model (while again, determined endogenously with the model's real side) exert an important influence on outcomes in the model's real-side. For example:

- the PSBR determines new liability issuance by government;

- gross fixed capital formation by industry determines new liability issuance by industry;

- household savings determines new asset acquisitions by households;

- the current account deficit determines new asset acquisitions by foreigners;

- pension fund contributions determine new liability issuance by the pension fund sector;

- changes in the weighted average cost of financial capital influences the desirability of undertaking gross fixed capital formation.

At the same time, linkages within the financial sector are modelled. For example, the commercial banking sector's roles as both a liability agent and as an asset agent are modelled, allowing detailed representation of the sector's activities in raising local and foreign deposit, 
bond and equity financing, and deploying the funds thus raised in the purchases of financial instruments such as loans to domestic industry for capital formation, and household mortgages for the purchase of new and existing dwellings. In this system, changes in prospects for one financial agent have consequences for the costs of funds to other agents.

\subsection{Monetary and regulatory transmission mechanism in the FCGE model}

Mishkin (1995) outlines four channels via which financial policy shocks can affect the economy: the interest rate channel, the exchange rate channel, the asset price channel, and the credit channel. While these channels are not modelled explicitly within our FCGE model, they nevertheless emerge from the identification of the financial agents and instruments, optimising behaviour, and financial / real economy links discussed in Section 2.1.

The interest rate channel describes the relationship between financial policy changes and real activity via the impact of interest rate movements on investment and other interest-sensitive expenditures (Mishkin (1995): 4). This mechanism is present in our FCGE model because investors are assumed to undertake capital formation up to the point where the expected rate of return on new units of physical capital is equal to the weighted average cost of the financial capital that they issue to finance the activity (see Dixon et al. (2015): 17]). Because the weighted average cost of financial capital is potentially sensitive to changes in bank lending rates (and indeed, via changes in the cost of other forms of financial capital), the interest rate channel is a potentially relevant mechanism in understanding how a change in commercial bank capital requirements can affect real activity within the FCGE model.

The exchange rate channel describes the capacity of monetary policy to influence real activity via interest rate induced movements in the exchange rate. Mishkin (1995): 5) summarizes the chain of causation thus: $i \uparrow \Rightarrow E \uparrow \Rightarrow N X \downarrow \Rightarrow Y \downarrow$. That is, a policy induced rise in interest rates ( $i \uparrow$ ) encourages capital inflow and thus exchange rate appreciation ( $E \uparrow)$. The exchange rate appreciation damps net exports ( $N X \downarrow)$, and with it, real GDP $(Y \downarrow)$. The exchange rate channel is an important short-run mechanism in the FCGE model, however we describe the sequence of transmission steps differently to Mishkin. While Mishkin's chain of causation emphasizes a demand-led connection between net exports and real GDP, our explanation emphasizes the neo-classical mechanism connecting employment (and thus output) to the real producer wage. That is, within the FCGE model, the chain of causation between a policy-induced rise in interest rates and real-side variables like GDP and net exports is: $i \uparrow \Rightarrow E \uparrow \Rightarrow P \downarrow \Rightarrow(W / P) \uparrow \Rightarrow L \downarrow \Rightarrow Y \downarrow \Rightarrow N X \downarrow$. Consistent with Mishkin, the first two steps in the chain link nominal appreciation with the rise in the interest rate. In the FCGE model, nominal appreciation causes a fall in the domestic price level ( $P \downarrow$ ) due to a fall in the domestic price of traded goods. With the nominal wage sticky in the short-run, this causes the real producer wage to rise $((W / P) \uparrow)$, and hence the demand for labour to fall ( $L \downarrow)$. With employment lower, real GDP must fall $(Y \downarrow)$. With stickiness in public consumption spending, real GNE is likely to fall by less than the fall in real GDP. Hence the balance of trade is likely to move towards deficit ( $N X \downarrow$ ). Hence the FCGE model's exchange rate channel mechanism anticipates similar impacts on real side variables as those outlined by Mishkin, but places 
more emphasis on the role of short-run wage stickiness in generating a temporary fall in employment via a rise in the real producer wage.

Mishkin outlines two asset price channel effects: one via a Tobin's $q$ mechanism, and the second via wealth effects on consumption. A mechanism like the first is present in the FCGE model. As Mishkin describes, monetary policy can affect the valuation of equities, and as such, affect investment via a Tobin $q$ mechanism. Tobin's $q$ is defined as the market price of firm equity divided by the replacement cost of firm physical capital. As Mishkin describes, when the value of $q$ rises, investment should rise because firms can issue new equities at a price that is high relative to the construction cost of capital. Mishkin describes the Tobin q channel linking monetary policy with real activity via: $i \uparrow \Rightarrow P_{e} \downarrow \Rightarrow q \downarrow \Rightarrow I \downarrow \Rightarrow Y \downarrow$. At the beginning of this chain, a rise in interest rates reduces equity prices because the resulting fall in bond prices causes equity prices $\left(P_{e}\right)$ to fall as investors switch from equities to bonds. This causes Tobin's $q$ to fall, thereby reducing investment as firms find it relatively more attractive to purchase capital by acquiring the equities of existing firms rather than by constructing new physical capital. A similar mechanism operates within the FCGE model. In our model, a rise in interest rates, including a rise in bank lending rates induced by a rise in mandated bank capital, causes the cost of equity finance to rise because firms must offer competitive rates of return when issuing new equity finance. Hence, a tightening of industry credit conditions, whether via tight monetary policy or a mandated rise in bank capital, raises the weighted average cost of financial capital faced by industries not only because it pushes up the cost of debt finance, but also because the portfolio-switching behaviour of asset agents forces issuers of new equity to offer higher rates of return on new equity. As discussed in Dixon et al. (2015): 17), with investors undertaking physical capital formation up to the point where the expected return on physical capital is equal to the weighted average cost of financial capital, a rise in the weighted average cost of financial capital will lower real investment in the FCGE model. The second asset price channel outlined by Mishkin relies on changes in equity values affecting household wealth, and with it, real consumption and real GDP. The FCGE model does not yet contain a direct link between household financial wealth and household consumption. This is a link we plan to explore in future work.

Mishkin identifies two broad credit channels: the balance sheet channel and the bank lending channel. The balance sheet channel rests on monetary and financial policy's capacity to affect lending behaviour via its impact on firm balance sheets and perceptions of lending risk. For example, as Mishkin argues, a tightening of monetary policy can adversely affect the net worth of firms by lowering their equity prices. The fall in firm net worth can then adversely affect bank lending by raising bank perceptions of adverse selection and moral hazard risks. The bank lending channel emphasizes the particular role that banks play as intermediaries for certain firms and sectors. As Kashyap and Stein (1994) note, summarizing Bernanke and Blinder (1988), three conditions must hold for a model to possess a distinct lending channel for monetary policy transmission: (i) liability agents must view as imperfect substitutes financial capital raised by loans from banks and bonds sold to the general public; (ii) banks must view deposit finance and other forms of short-term finance as imperfect substitutes; and (iii) there must be a nominal rigidity that prevents monetary shocks from having no impact on the real economy. All three conditions hold in the FCGE model. Condition (i) ensures that 
borrowers cannot entirely offset a rise in the cost of bank funds by shifting to other sources of financial capital. Condition (ii) renders the cost of funds to commercial banks sensitive to changes in the costs of particular finance sources (like deposits) by ensuring that they cannot make costless switches between alternative funding sources. Condition (iii) ensures that changes in monetary policy are not immediately neutralized by costless price adjustment. These three conditions hold in the FCGE model, thus allowing a shock directed at commercial banks (like a rise in the capital adequacy ratio) to exert an influence on the cost of financial capital to agents reliant on bank finance (like housing construction).

\subsection{Modelling the capital adequacy ratio}

Modelling of the capital adequacy ratio requires us to depart, for commercial banks, from the default modelling of asset and liability optimization on the part of financial agents as described in Dixon et al. (2015). First, the theory describing bank decision making over asset ownership must recognise differences in capital requirements across risky assets. Second, we must activate theory that allows movements in the capital adequacy ratio to affect the amount of equity that banks hold on the liability side of their balance sheets. We expand below, following a similar approach to that in Giesecke et al. (2016).

\subsubsection{Asset demand by commercial banks}

To model the effects of the capital adequacy ratio and risk weights on commercial bank behaviour, we begin by modifying the standard theory in the FCGE model governing decision making by asset agents. We assume that commercial banks (ComB) choose their end-of-year asset portfolio, $\mathrm{A} 1_{(s, f, \text { ComB })}$ for all $s$ and $f$ to maximize

$\mathrm{U}\left(\mathrm{R}_{(\mathrm{s}, \mathrm{f}, \mathrm{ComB})} \times \mathrm{A1}_{(\mathrm{s}, \mathrm{f}, \mathrm{ComB})}\right.$, for all s and $\left.\mathrm{f}\right)$

subject to

$\sum_{\mathrm{s}, \mathrm{f}} \mathrm{A}_{(\mathrm{s}, \mathrm{f}, \mathrm{ComB})}=\mathrm{BB}_{(\mathrm{ComB})}$

and

$\sum_{\mathrm{d}} \mathrm{A} 1_{(\text {ComB,equity,d) }}=$

$\operatorname{MAX}\left[\sum_{\mathrm{d}} \operatorname{A1zero}_{(\mathrm{ComB}, \text { equity, } \mathrm{d})}, \mathrm{KAR} \times \sum_{\mathrm{s}, \mathrm{f}} \mathrm{W}_{(\mathrm{s}, \mathrm{f}, \mathrm{ComB})} \times \mathrm{A1}_{(\mathrm{s}, \mathrm{f}, \mathrm{ComB})}\right]$

where

KAR is the capital adequacy ratio, $\mathrm{W}_{(\mathrm{s}, \mathrm{f}, \mathrm{ComB})}$ is the risk weight that the financial regulator assigns to $A 1_{(s, f, C o m B)}$, $A 1 z e r 0_{(C o m B, e q u i t y, d)}$ is the value of equity the commercial banks would have on issue in the absence of capital adequacy requirements, $\mathrm{BB}_{(\mathrm{ComB})}$ is the total value 
of commercial bank assets, and $\mathrm{U}$ is a constant elasticity of substitution function. We assume that the KAR constraint is binding so $\sum_{\mathrm{d}} \mathrm{A} 1_{(\mathrm{ComB}, \text { equity,d) }}=\mathrm{KAR} \times \sum_{\mathrm{s}, \mathrm{f}} \mathrm{W}_{(\mathrm{s}, \mathrm{f}, \mathrm{ComB})} \times \mathrm{A} 1_{(\mathrm{s}, \mathrm{f}, \mathrm{ComB})}$.

Equity liabilities are relatively expensive. Consequently, we approximate problem (1) through (3) as:

Choose $A 1_{(s, f, \text { ComB })}$ for all $s$ and $f$

to maximize

$\mathrm{U}\left(\mathrm{NR}_{(\mathrm{s}, \mathrm{f}, \mathrm{ComB})} \times \mathrm{A1}_{(\mathrm{s}, \mathrm{f}, \mathrm{ComB})}\right.$, for all s and $\left.\mathrm{f}\right)$

subject to

$\sum_{\mathrm{s}, \mathrm{f}} \mathrm{A}_{(\mathrm{s}, \mathrm{f}, \mathrm{ComB})}=\mathrm{BB}_{(\mathrm{ComB})}$

where

$\mathrm{NR}_{(\mathrm{s}, \mathrm{f}, \mathrm{ComB})}=\mathrm{R}_{(\mathrm{s}, \mathrm{f}, \mathrm{ComB})}-\Psi \times \mathrm{KAR} \times \mathrm{W}_{(\mathrm{s}, \mathrm{f}, \mathrm{ComB})}$

and

$\Psi$ is a positive parameter.

In (6) we recognize that the commercial banks face a penalty when they expand their holding of asset $(\mathrm{s}, \mathrm{f}, \mathrm{ComB})$. The penalty is that they have to increase expensive equity liabilities. We model the penalty as proportional to the capital adequacy ratio times the risk weight. The factor of proportionality, $\Psi$, reflects the difference between the cost of equity finance to the commercial banks and the cost of other liabilities. For example, with $\Psi$ at 0.08 , and $K A R=0.1$, the penalty for a risky asset with weight $1(W=1)$ would be 0.008 (80 basis points). This is because the acquisition of an additional $\$ 1$ of the risky asset requires that the bank raise $\$ 0.1$ of additional equity finance, costing 800 basis points more than nonequity finance. If the capital adequacy ratio were increased to 0.125 then the penalty for risky assets would increase to 0.01 (an increase of 20 basis points), whereas the penalty for a less risky asset ( $W=0.1$, say) would barely move, from 0.0008 to 0.001 (an increase of 2 basis points). By changing the capital adequacy ratio and/or the risk weights the regulator can influence the asset choices of the commercial banks.

\subsubsection{Commercial bank liabilities and equity}

For details on the modelling of the liability side of commercial bank balance sheets, we refer the reader to Dixon et al. (2015), particularly pp. 9-10, 12-13 and 17-19. Here, we draw out the key parts of the discussion in that paper that are relevant to the current simulation. In particular, we begin by reproducing the following four percentage change equations from Dixon et al. (2015): 
RABANK $\times$ prabank $=$
$\sum_{s \in L A} \sum_{f \in F I}\left[\right.$ RISKWGT $\left._{(\mathrm{s}, \mathrm{f})} \times \mathrm{A1}_{(\mathrm{s}, \mathrm{f}, \mathrm{ComB})}\right] \times\left(\operatorname{priskwgt}_{(\mathrm{s}, \mathrm{f})}+\mathrm{a} 1_{(\mathrm{s}, \mathrm{f}, \mathrm{ComB})}\right)$

(8) $\quad$ EQBANK $\times$ peqbank $=\sum_{d \in A A} \mathrm{~A} 1_{(\text {ComB,Equity,d) }} \times \mathrm{a}_{(\text {ComB,Equity,d) }}$

(9) $\quad$ pratio $=$ peqbank - prabank

$$
\begin{aligned}
& \operatorname{BBNEQ}_{(\mathrm{ComB})} \times \text { pbblneq }_{(\mathrm{ComB})}= \\
& \mathrm{BBL}_{(\mathrm{ComB})} \times \mathrm{pbbl}_{(\mathrm{ComB})}-\sum_{d \in A A} \mathrm{~A}_{(\mathrm{ComB}, \mathrm{Equity}, \mathrm{d})} \times \mathrm{a}_{(\mathrm{ComB}, \mathrm{Equity}, \mathrm{d})} \\
& \text { averorne }_{(\mathrm{ComB})}=\sum_{d \in A} \sum_{f \in F I N E Q}\left[\mathrm{~A}_{(\mathrm{ComB}, \mathrm{f}, \mathrm{d})} / \mathrm{BBNEQ}_{(\mathrm{ComB})}\right] \times \mathrm{rpow}_{(\mathrm{ComB}, \mathrm{f}, \mathrm{d})}
\end{aligned}
$$

$$
\left.\mathrm{a}_{(\mathrm{ComB}, \mathrm{f})}=\text { pbblneq }_{(\mathrm{ComB})}+\mathrm{TAU} \times \operatorname{rrpowd}_{(\mathrm{ComB}, \mathrm{f})}-\text { averorne }_{(\mathrm{ComB})}\right](\mathrm{f} \in \text { FINEQ})
$$

where:

$\mathrm{BBL}_{(\mathrm{ComB})}$ is the level of total end-of-year commercial bank liabilities (including equity);

$\mathrm{BBNEQ}_{(\mathrm{ComB})}$ is the level of the equity-exclusive value of end-of-year commercial bank liabilities;

RABANK is the level of the value of end-of-year risk-weighted bank assets;

RISKWGT $_{(s, f)}$ is the level of the risk weights attaching to financial instrument $f$ issued by liability agent $s$;

$\mathrm{A} 1_{(\mathrm{s}, \mathrm{f}, \mathrm{d})} \quad$ is the level of end-of-year holdings by agent $d$ of asset type $f$ issued by agent $s$;

TAU is a parameter governing the sensitivity of the composition of commercial bank liabilities to changes in the relative costs of financial instruments issued to particular asset agents;

EQBANK is the value of bank equity;

prabank is the percentage change in risk-weighted bank assets;

priskwgt $_{(s, f)}$ is the percentage change in the value of the risk weight attached to commercial bank holdings of financial instrument $f$ issued by liability agent $s$;

$\mathrm{a} 1_{(\mathrm{s}, \mathrm{f}, \mathrm{d})} \quad$ are the percentage changes in end-of-year holdings by agent $d$ of asset type $f$ issued by agent $s$;

peqbank is the percentage change in end-of-year bank equity;

pratio is the percentage change in the capital adequacy ratio; 
pbblneq $q_{(\mathrm{ComB})}$ is the percentage change in the equity-exclusive value of commercial bank liabilities;

$$
\begin{aligned}
& \operatorname{pbbl}_{(\mathrm{ComB})} \quad \text { is the percentage change in end-of-year (equity-inclusive) commercial bank } \\
& \text { liabilities; }
\end{aligned}
$$

averorne $_{(\mathrm{ComB})}$ is the percentage change in the average rate of return on non-equity financial instruments issued by commercial banks as liability agents;

$\operatorname{rpow}_{(\mathrm{ComB}, \mathrm{f}, \mathrm{d})}$ is the percentage change in the power (1 plus the rate) of the rate of interest / return paid to asset agent $d$ on financial instrument $f$ issued by commercial banks as liability agents;

$\mathrm{a}_{(\mathrm{d}} \mathrm{ComB,f}_{\mathrm{f}} \quad$ is the percentage change in end-of-year non-equity liabilities ( $\mathrm{f} \in$ FINEQ i.e., deposits, loans, and bonds) issued by commercial banks as liability agents;

rpowd $d_{(s, f)} \quad$ is the percentage change in the power of the rate of interest paid by commercial banks on non-equity financing instrument $f$.

Equation (7) calculates the percentage change in the risk-weighted value of end-of-year commercial bank assets. The risk weight on financial instrument $f$ issued by liability agent $s$ and held as an asset by commercial banks is given by RISKWGT $($ s,f). Table 1 gives values for the risk weights in (7), which mirror the corresponding values adopted in Giesecke et al. (2016). In choosing values for RISKWGT $_{(s, f)}$, we were guided by our desire to explore the impact of differences in the macroeconomic and financial structures of Australia and the U.S. Nevertheless, as we shall discuss in section 2.5.3.2, in constructing the USAGE2F financial database we classify GSE mortgage backed securities as Equity, and hence we implicitly assign a risk weight of 3.0 to these securities. As outlined by Natter (2012), under U.S. Basel III regulations this is akin to an assumption that all GSE mortgages are backed by a pool of category 2 residential mortgages, with loan-to-value ratios of greater than 90 per cent. As we discuss in section 4 , in future work we intend to develop a U.S.-specific array of risk weights.

Equation (8) calculates the percentage change in end-of-year bank equity as the share weighted sum of the percentage changes in bank equity held by all asset agents. Equation (9) calculates the percentage change in the capital adequacy ratio, defined as the ratio of end-of-year bank equity to risk-weighted assets.

With equation (9) activated, in the sense that pratio is determined exogenously, thus enforcing a given ratio of equity to risk-weighted assets, we must provide for the non-equity component of bank financing to be determined outside of the standard liability optimisation mechanisms summarised in Section 2 herein, and detailed in Section 3.8 of Dixon et al. (2015). This is provided by equations (10), (11) and (12). Equation (10) calculates the nonequity financing needs of commercial banks ( $\left.p b b / n e q_{(\text {соmв })}\right)$ as the difference between total (equity-inclusive) bank financing needs $\left(\mathrm{pbb}_{(\mathrm{ComB})}\right)$ and that part of bank financing needs satisfied by equity. Equation (11) calculates the weighted average value of the cost of non- 
equity finance to agent (s). Equation (12) establishes bank liability optimising behaviour over the issuance of non-equity financing instruments.

\subsection{The central bank policy rate and the Taylor rule}

In section 2.1 we introduced the data arrays describing stocks of financial instruments $\left(A_{(s, f, d)}\right)$ and the rates of return on those stocks $\left(R_{(s, f, d)}\right)$. These data include two instruments relevant to the relationship between the central bank and commercial banks as it pertains to the operations of monetary policy within the FCGE model, namely:

1. $A_{(\text {CenB,DeposLoans,ComB) }}$ and $R_{(\text {CenB,DeposLoans,ComB), }}$ describing commercial bank holdings of clearing balances with the central bank, and the rate of return paid by the central bank on those balances.

2. $A_{\text {(ComB,DeposLoans,CenB) }}$ and $R_{\text {(ComB,DeposLoans,CenB), }}$ describing commercial bank borrowings of clearing balances from the central bank, and the rate of interest charged by the central bank on those balances.

3. $F_{(G o v t, B o n d s, C o m B)}$, describing purchases and sales of domestic government bonds by the central bank.

Consistent with the channel system operated by the Australian central bank (e.g. Otto (2007), Woodford (2001)) and applied in Giesecke et al. (2016), we begin with the idea that both $\mathrm{R}_{\text {(CenB,DeposLoans,Com) }}$ and $\mathrm{R}_{\text {(Com,DeposLoans,CenB) }}$ are policy variables, with $\mathrm{R}_{\text {(ComB,DeposLoans,CenB) }}=$ $\mathrm{R}_{\text {(CenB,Deposloans,ComB) }}+0.005 .{ }^{4}$ We assume that the central bank maintains a given supply of commercial bank exchange settlement balances $\left(\mathrm{A}_{(\mathrm{CenB}, \mathrm{Depos} L \mathrm{oans}, \mathrm{ComB})}\right)$ at the rate $\mathrm{R}_{\text {(CenB,DeposLoans,ComB) }}$ via open market operations in the domestic government bond market $\left(\mathrm{F}_{(\text {Govt }, \text { Bonds, CenB })}\right) .^{5}$

Under the closure described above, $R_{\text {(ComB,DeposLoans, CenB) }}$ is exogenous, with $R_{\text {(CenB,DeposLoans,ComB) }}$ formally endogenous but uniquely determined by the exogenous status of $R_{\text {(ComB,DeposLoans,CenB) }}$ via the relationship $R_{(\text {ComB,DeposLoans,CenB) }}=R_{(\text {CenB,Depostoans,ComB) }}+0.005$. We endogenise $\mathrm{R}_{\text {(ComB,Depostoans, CenB) }}$ by introducing a Taylor rule linking movements in the policy rate to

${ }^{4} R_{(s, f, d)}$ is defined as the power of the rate of return (i.e. 1 plus the rate) earned by asset agent $d$ on financial instrument $f$ issued by liability agent $s$. Hence, if the deposit rate for settlement balances with the central bank is 3 per cent, then $R_{(C B, D e p o s L o a n s, B a n k s)}=1.03$ and the power of the borrowing rate for settlement balances $\left(R_{\text {(Banks,DeposLoans, } C B)}\right)$ is 1.035 .

${ }^{5}$ This is consistent, for example, with the channel system description in Woodford (2003). He describes a channel system as one in which the central bank supplies a given level of clearing balances at a given policy interest rate, in addition to standing ready to lend clearing balances at a fixed spread over the policy rate (Woodford (2003): 27]. This is also consistent with early descriptions of how the Reserve Bank affects changes in the policy rate. For example, Lowe (1995), p.3]: "Monetary policy operates via the Bank influencing the interest rate paid on overnight funds (the "cash rate")...The Bank's influence over the cash rate comes from its ability to control the availability of funds used to settle transactions between financial institutions. By undertaking open market operations, principally in government securities with less than one year to maturity, the Bank controls the availability of settlement funds and hence the interest rate paid on overnight deposits". 
deviations of inflation from target and the employment rate from the natural rate. As Orphanides (2007) describes, Taylor rules are simple prescriptive policy rules describing how a central bank should adjust its policy interest rate in response to movements in inflation and economic activity. The "classic Taylor rule" proposed by Taylor (1993) is:

$$
r=(2+p)+0.5(p-2)+0.5 y
$$

where $r$ is the federal funds rate, $p$ is the rate of inflation over the previous four quarters, " 2 " denotes an assumed natural real rate for the policy rate of 2 per cent per annum (in the first bracketed term) and a target inflation rate of 2 per cent per annum (in the second bracketed term), and $y$ is an output gap measure calculated as the percent deviation of real GDP from potential $\left(\mathrm{Y}^{*}\right)$, i.e., $y=100\left(\mathrm{Y}-\mathrm{Y}^{*}\right) / \mathrm{Y}^{*}$.

Within the FCGE model, we link movements in the policy interest rate to deviations in the price level from target and output from potential via the following adjustment process:

$$
\left(\frac{R_{(\text {CenB,DeposLoans,ComB }) t}}{R_{(\text {CenB,DeposLoans, ComB }) t-1}}\right)=F R\left(\frac{P_{t}}{P_{t}^{(T)}}\right)^{\alpha}\left(\frac{E R_{t}}{E R_{t}^{(T)}}\right)^{(1-\alpha)}
$$

where $R_{(\text {CenB,DeposLoans,ComB )t }}$ and $R_{(\text {CenB,DeposLoans,ComB )t-1 }}$ are the current and lagged powers of the interest rate offered by the central bank on settlement balances, $P_{t}$ and $P_{t}^{(T)}$ are the actual and target levels for the consumer price index in year $t, E R_{t}$ and $E R_{t}^{(T)}$ are the actual and target levels of the employment rate (1-the unemployment rate) in year $t, F R$ is an exogenous shift variable, and $\alpha$ is a parameter (set at 0.5 ) governing the sensitivity of interest rate movements to deviations in prices and employment from target. Converting (14) to a percentage rate of change form, we have:

$$
r_{(\text {CenB }, \text { DeposLoans }, \text { ComB }) t}=r_{(\text {CenB,DeposLoans }, \text { ComB }) t-1}+0.5\left(p_{t}-p_{t}^{(T)}\right)+0.5\left(e r_{t}-e r_{t}^{(T)}\right)+f r
$$

where $r_{(\text {CenB,DeposLoans,ComB }) t}$ and $r_{(\text {CenB,DeposLoans,ComB }) t-1}$ are the current and lagged percentage changes in the power of the interest rate offered by the central bank on settlement balances, $p_{t}$ and $p_{t}^{(T)}$ are the actual and target rates of consumer price inflation in year $t, e r_{t}$ and $e r_{t}^{(T)}$ are the actual and target percentage changes in the employment rate (1-the unemployment rate) in year $t$, and $f r$ is a shift variable that is endogenous when the policy rule is inactive and exogenous (and typically unshocked) when the rule is activated.

\subsection{Constructing the USAGE2F financial database}

The basis of the financial module in USAGE2F is the USAGE2F financial database, which is constructed using data from the Flow of Funds Accounts (FoFs) prepared by the Federal Reserve Board and released as part of the Board of Governors of The Federal Reserve System Statistical Release Z.1. (2015). These accounts record the acquisition and sales of nonfinancial 
and financial assets throughout the U.S. economy, the sources of the funds used to acquire those assets, and the value of the assets held and the liabilities owed on a by-agent basis BEA (2014). More specifically, by-agent and by-instrument transactional data reporting can be defined in the following way:

1. A by-financial-agent basis. For a given financial asset agent, the US\$b value of financial instruments they purchased as assets or issued as liabilities in each sample year are aggregated and listed in a single report. The liabilities issued in any given year need not sum to the value of assets purchased in each sample year; the difference between the two can then be linked to net investment in nonfinancial assets by the given agent and the change in the net worth of the given agent. This data is given in items F.100 through to F.132. of the Board of Governors of The Federal Reserve System Statistical Release Z.1. (2015). Specific counterparties to each transaction are not specified in F.100 through to F.132, e.g., for item F. 129 Security Brokers and Dealers, we are given the dollar value of Corporate Bonds issued as liabilities in 2013 by Security Brokers and Dealers as US\$11.5b, however we are not told which asset agent purchased these Bonds as assets.

2. A by-financial-instrument basis. For a given financial instrument, the US\$b value of that instrument purchased as an asset or issued as a liability in each sample year is summarised in a single report. Where possible, the Board of Governors of The Federal Reserve System Statistical Release Z.1. (2015) includes a financial agent dimension by listing the US\$b of the given instrument purchased (as an asset) and issued (as a liability) by each financial agent. This data is given in items F. 200 through to F. 233 of the Board of Governors of The Federal Reserve System Statistical Release Z.1. (2015). Specific counterparties to each transaction are not specified however, e.g., for item F. 212 Corporate and Foreign Bonds, we are given the dollar value of Bonds issued as liabilities by Brokers and Dealers in 2013 as US\$11.5b, however we are not told who purchased this agent's Bonds as an asset. The US\$b value of financial assets purchased in any given sample year must equal the value of liabilities issued, i.e., there must be a suitable counterparty to each financial transaction. In this sense, they provide a suitable reference for a detailed description of the U. S. Financial Accounts. We explore the data presented in the FRSR in section 2.5.1.

In what follows, we describe the various agents and instruments that appear in FRSR0615, and the mapping of this broad set of agents and instruments to the final set adopted for the USAGE2F financial database.

\subsubsection{A description of the Board of Governors of The Federal Reserve System Statistical}

Release Z.1. (2015)

The Board of Governors of The Federal Reserve System Statistical Release Z.1. (2015) (from henceforth we shall refer to this reference as FRSR0615) provided the bulk of the underlying data for the model. The stocks and flows included in FRSR0615 are commonly referred to as the Flow of Funds Accounts or the FoFs; see BEA (2014). 
The financial flows in the FoFs are prepared using financial account data from the International Transactions Accounts (ITAs), which are prepared by the U.S. Bureau of Economic Analysis (BEA). The ITAs detail three key flow of fund accounts, namely the (i) Current Account; (ii) Capital Account; and (iii) Financial Account. The principal focus of FRSR0615 is the financial account. Our work herein aims to utilise the financial account data in FRSR0615 to link the Current and Capital Accounts (that are already modelled in USAGE

2.0) to the financial account of the U.S. When combined with annual end-of-year stocks/levels data in FRSR0615 that is taken from the International Investment Position Accounts (IIPs, a statistical summary of the accumulated stocks of U.S. assets and liabilities and the U.S. net foreign debt), we can thus provide a complete picture of U.S. International financing requirements and funding sources.

For this reason, FRSR0615 was a key building block of the database construction. This statistical release lists the financial assets and liabilities of twenty-nine U.S. agents, together with a single agent representing the foreign investor. In all, twenty-seven financial instruments that represent high-level aggregates of several underlying financial instruments are used to outline each respective agent's financial assets and liabilities (funding sources). All figures are reported in US\$b; we adopt the same convention herein. In what follows, we provide a description of the agents and instruments in FRSR0615, and outline the mapping of these agents to our eleven agent/five instrument description in the USAGE2F financial database.

\subsubsection{Agents}

\subsubsection{FRSR0615 specifications}

The set of 30 financial asset and liability agents in FRSR0615 are summarised in Table 2. These financial agents include:

o A single Household agent. Household liabilities include Credit, Automobile and Student Loans, as well as home, commercial, and farm mortgages;

o Disaggregated Federal Government and State and Local Government agents, facilitating direct analysis of policy issues regarding the Federal Government Budget Deficit;

o Private Depository Institutions (an aggregate of domestic and foreign banks, credit unions and U.S. banks in foreign affiliates) that are disaggregated from other financial organisations, e.g., various Mutual Fund Managers, Exchange Traded Fund managers, Insurers, and the Government Sponsored Entities (GSE's). This facilitates a direct analysis of the U.S. mortgage issuant market;

o Two superannuation agents are included to treat Defined Benefit Funds distinctly relative to their Defined Contribution Fund counterparts. In future, this will provide an opportunity to explore how different retirement savings structures can affect the broader macro economy, e.g., mandated Defined Contribution superannuation contributions vs Defined Benefit contributions; 
- A single Foreign agent. As we shall discuss, this agent's activities are linked to the net foreign debt and current account balance of the U.S.;

o We also defined an artificial agent called ResidentRE, which manages the residential property stock of the U.S. This agent is a useful economic construct, in the sense that, while no single physical or legal agent exists which owns all the residential property in the U.S., it is helpful in modelling financing of housing ownership and construction to locate economy-wide decision making over such matters within one agent.

\subsubsection{USAGE2F Database}

The aggregated set of 11 asset and liability agents are listed Table 3 and have been adopted from previous work by Dixon et al. (2015) and Giesecke et al. (2016). A short description of each agent is also provided Table 3. To evaluate the USAGE2F financial database, we defined a mapping of the FRSR062015 agents in Table 2, to the USAGE2F database agents in Table 3. This mapping is summarised in Table 4, whilst some details of the mapping are given below:

- The single household agent in the disaggregated database is mapped to the single Household agent (Households) in the USAGE2F database. As discussed in section 2.5.2.1, the Household agent in FRSR0615 is an active liability agent. Following the approach in Dixon et al. (2015), we model the Household agent as a net asset agent by netting off some of their liabilities against other assets held by the Household.

o We considered pairs of appropriate instruments to net off against one another on an instrument-by-instrument basis, following the mapping of the (larger) set of FRSR0615 instruments to the 5-instrument-representation in the USAGE2F database. This process is discussed further in section 2.5.3;

- The single foreign agent in the FRSR0615 data is mapped to the foreign agent (Foreigner) in the USAGE2F database. No additional modifications are made, so as to preserve the key current account and net foreign debt statistics;

- The Private Depository Institutions (mapped to Banks) remain disaggregated from other financial institutions, e.g., Non-Bank Financial Institutions (NBFI);

- As shown in Table 4, GSE's are mapped with other non-bank financial institutions from the FRSR0615 data, to the NBFI agent in the USAGE2F database;

- A single Government agent now represents both the Federal and State and Local Governments;

- Both Defined Benefit and Defined Contribution superannuation funds are mapped to the Retirement agent;

- As per the approach in Dixon et al. (2015), we split the residential real estate sector (ResidentRE) into the reproducible housing and non-reproducible housing sectors. 


\subsubsection{Instruments}

\subsubsection{FRSR0615 specifications}

In what follows, we summarise set of financial instruments identified in FRSR0615. The final set of 27 financial instruments in Table 5 includes:

- Twenty-seven distinct financial instruments;

o Fixed Income investments (or what would typically be bundled together under the broad umbrella of Bonds) span six distinct instruments, all of which offer distinct risk/return trade-offs to asset and liability agents. These are Bonds (Corporate bonds with maturities $>1$ year), Commercial paper with maturities $<1$ year (ComPaper), Non-marketable Treasury Securities (NMTreasuries), Treasury Bills (maturity <1 year, TBills), longer-dated treasury securities (Treasuries) and U. S. Savings Bonds (USSavingsBnd);

o Mortgages are broken down into four types, which are distinguished by the asset over which the mortgage is held: Residential Property Loans (HomeLoan), Commercial Property Loans (ComPropLoan), Multi-family/Apartment loans (MultiFamLoan) and Farm Loans excluding the Farm House (FarmLoan). Pools of asset-backed securities (including mortgage-backed securities) are recorded distinctly as ABSecurities;

O Other forms of consumer credit are also distinctly recorded and include Automotive Loans (AutoLoan), Credit Card Debt (CardDebt) and Student Loans (StudentLoan);

o General business and personal loans are recorded under a single Loans instrument;

o Foreign direct investment is decomposed into Debt and Equity financing (FDIDebt and FDIEquity, respectively);

o Four key instruments in the Federal Reserves' attempts to implement their target Cash Rate and settle overnight obligations between the various depository institutions in the economy are disaggregated from one another. These are depository institution reserves held at the Fed (labelled Reserves, and amounting to 10.6 per cent of the overall financial asset holdings of U.S. commercial banks in 2013), the overnight loans facility (OvrNghtLoan), asset repurchase agreements (Repurps), and reverse asset repurchase agreements (RevRepurps). This facilitates a detailed exposition of the implementation and the impact of changes to monetary policy in the U.S.;

o The remaining financial instruments include several standalone instruments, such as Cash, Equity, Currency, Special Drawing Rights (SDR) and general receivables (Receivables). An additional instrument is included to capture insurance or superannuation receivables and reserves (LifePenRes), which are significant in their own right when considered relative to other general receivables. 


\subsubsection{USAGE2F Database}

The set of 5 instruments included in the USAGE2F database are listed and described in Table 6; as before, the instruments in the USAGE2F database are adopted from previous work by Dixon et al. (2015). The mapping of the set of FRSR0615 instruments to the smaller set of USAGE2F instruments is outlined in Table 7, with the following notes:

- Because asset-backed securities are typically marked-to-market ${ }^{6}$, herein we made the assumption that such securities deliver Equity-like risk exposures. ABSecurities were therefore mapped to Equity.

- As discussed in section 2.5.2, the Household agent is modelled as a net asset holder in the USAGE2F database. To facilitate this representation of the Household agent, we performed the instrument mapping as outlined in Table 7; we subsequently decided whether to net the liabilities against other assets held by the agent or to simply disregard them, i.e., set them to zero. Our aim was to minimise the impact of our actions on key macro statistics that link the financial database to the real economy, e.g., the current account deficit and net foreign debt positions of the U. S. These linkages are discussed in section 2.1, while our netting procedure is presented in the bullet points that below.

o All household HomeLoan and MultiFamLoan liabilities are reallocated from the Household agent to the artificial agents NRH and RH. The household therefore owns a net equity position in the NRH and RH agents, representing their net equity in U.S. residential property. This is as per the approach in Dixon et al. (2015).

o Other household liabilities were:

1. DepLoans: Aggregate of StudentLoan , CardDebt, AutoLoan and Personal/Other loans (Loans);

2. Bonds: Issued by not-for-profits, domestic hedge funds or private equity firms, with Households unable to access the commercial bond market;

3. Equity: In the form of insurance contract payables and other receivables.

o We address the treatment of each of $1-3$ above separately:

- Student loan liabilities are assets of the Government and four other agents in FRSR0615; they are the largest single component of Household DepLoans liabilities. As such, setting the sum of all Household DepLoans liabilities would significantly impact the net Government debt implied by the database. We therefore net off StudentLoan's made by the Government agent to Households, against Households asset holdings of Treasuries (liabilities of Government).

- Holdings of Household Bond liabilities by the key Government and Foreigner agents are small relative to their holdings of other assets (representing 0.4 per cent and 0.1 per cent of the Government and Foreigner bond portfolios in at the end of 2013 respectively). We also

\footnotetext{
${ }^{6}$ For a case study of how mark-to-market practises in asset-backed security exposures contributed to the collapse of some US financial institutions and hedge funds during the GFC, see http://www.investopedia.com/articles/financial-theory/08/mark-to-market-mayhem.asp and http://www.investopedia.com/university/credit-crisis/credit-crisis4.asp
} 
suspect that these Bonds were not issued by Households but by residual financial agents; see section 2.5.2.1 for a discussion. For simplicity, we therefore set this liability position to zero.

- Household Equity liabilities were held as assets by Industry, Government, Life Insurers, NBFI and the Foreigner. The Household agent also holds the various Equity liabilities issued by each of these agents as an asset. We therefore made an assumption that in incurring Equity liabilities, e.g., trade/tax payables, with any given agent in the model, the Household agent is required to sell down their own Equity assets in those agents to fund these liabilities. In line with this assumption, Household Equity liabilities in from FRSR0615 are simply net off against Equity assets in the USAGE2F database.

\section{Simulations}

\subsection{Background}

Recent work by Giesecke et al. (2015) examined the impact on Australia of a 100 basis point increase in the capital adequacy ratio. As discussed in section 0 , in this article we adopt similar model specifications and use an equivalent shock to explore the impact of differences in the macroeconomic and financial structure between the U.S. and Australia, and the implications of these differences on the macroeconomic impact of a rise in the capital adequacy ratio.

\subsection{Closure}

We make the following closure assumptions, in line with those in Giesecke et al. (2016):

i) We assume that the nominal wage is sticky in the short run, but sufficiently flexible over the medium term to ensure that the unemployment rate returns to its natural rate;

ii) We assume that real public consumption is unaffected by the movement in the capital adequacy ratio. That is, real public consumption follows its baseline path. We further assume that the ratio of public sector borrowing to GDP also follows its baseline path. The exogenous status of both public consumption and the PSBR / GDP ratio requires the flexible determination of at least one government revenue instrument. To this end, we endogenously determine a direct tax on household income;

iii) The policy interest rate in year $t$ adjusts relative to its $t-1$ level in response to movements in the consumer price inflation rate away from target, and movements in the employment rate (an output gap measure) away from target.

\subsection{Discussion of results}

The shock is a 100 basis point increase in the capital adequacy ratio of commercial banks

(Figure 1). Via the mechanisms described in section 2.3, this causes banks to undertake 
adjustments to the composition of both the liability and asset sides of their balance sheets. On the liability side, the increase in the capital adequacy ratio causes commercial banks to increase their issuance of equity instruments, and decrease their reliance on deposit and bond financing (Figure 2). On the asset side of bank balance sheets, the rise in the capital adequacy ratio induces commercial banks to reduce their holdings of risky assets. We see this in Figure 3 and Figure 4. In Figure 3, we see a decline in the level of bank financial assets relative to the baseline (in which the capital adequacy ratio remains unaltered), while the proportion of riskweighted assets relative to total bank assets also falls. In Figure 4, we see the composition of bank asset holdings shifting away from assets with comparatively high risk weightings (such as foreign loans, loans to reproducible housing and industry, and foreign and industry equity), and towards those with lower risk weightings (domestic government bonds, loans to nonbank financial institutions [NBFI's]).

As discussed on the previous page, the rise in the capital adequacy ratio causes commercial banks to raise additional equity finance, and to reduce their demands for deposit and loan finance (Figure 2). To attract asset agents to acquire the new equity, rates of return on bank equity must rise (Figure 5). Figure 6 reports the deviation in the weighted average cost of capital (WACC) to commercial banks, which increases relative to baseline, as banks increase the equity share of their financing needs.

Concurrently, commercial banks reduce their demand for loan and deposit finance, allowing them to secure loan and deposit financing at slightly lower rates of return relative to baseline (Figure 5). 64.9 per cent of commercial bank deposits are financial assets of U.S. households, representing 12.3 per cent of households' overall financial asset portfolio. The fall in the rate of return on commercial bank deposits therefore induces households to rebalance their financial assets away from commercial bank deposits, and towards other financial assets, such as industry equity (21.5 per cent of household financial assets, making up 39.5 per cent of aggregate industry financial liabilities), NBFI equity (12.4 per cent of household financial assets, making up 30.8 per cent of aggregate NBFI financial liabilities), reproducible housing equity (which make up 21.2 per cent of reproducible housing financial liabilities), and bank equity. This rebalancing is highlighted in Figure 7, where we plot the deviations in the end-ofyear financial assets of U.S. households from their baseline values.

Figure 8 reports the deviations in the financial assets and liabilities of commercial banks. ${ }^{7}$ As discussed in Dixon et al. (2015), banks are assumed to operate under an environment of a fixed margin on the return they earn on financial assets and the return they must pay on their financial liabilities. This has the effect of requiring the commercial banks to pass on the increase in the cost of their financial capital (Figure 6) to the agents to whom they lend. This reduces demand for loans from commercial banks. That is, it leads to a contraction in commercial bank ownership of financial assets (Figure 8). Hence, commercial banks need to raise less financial capital to acquire this smaller pool of financial assets. That is, it leads to a contraction in commercial bank financial liabilities (Figure 8).

\footnotetext{
${ }^{7}$ We assume that commercial bank physical assets (primarily bank branches) are unaffected. Hence, in Figure 7, the percentage deviation in financial assets lies below the percentage deviation in liabilities.
} 
A special feature of the U.S. financial market is the presence of U.S. Government Sponsored Entities (GSE's), e.g., the Federal National Mortgage Association (Fannie Mae) and the Federal Home Loan Mortgage Corporation (Freddie Mac), who each act as secondary market makers for U.S. mortgages. ${ }^{8}$ Their role in the U.S. mortgage market is significant, with 67.7 per cent of U.S. reproducible housing loans held as financial assets of the NBFI's. ${ }^{9}$ This accounts for 42.5 per cent of the aggregate financing requirement of the reproducible housing sector. A much smaller proportion of aggregate U.S. housing loans liabilities are held as financial assets by the commercial banks (28.7 per cent).

Given the importance of the NBFI sector as a funder of U.S. housing investment activity, the aforementioned increase in demand for NBFI equity by households (Figure 7) has important implications for the supply of loan finance to the reproducible housing industry. As shown in Figure 2, the commercial banks reduce their appetite for deposits as their capital adequacy ratio is increased. With commercial bank deposits making up 12.3 per cent of household financial assets, this triggers a rebalancing by the household agent, away from commercial bank deposits and towards other assets. With 12.4 per cent of household financial assets being NBFI equity, and the majority of NBFI financial activities being equity financed ( 56.9 per cent), the fall in the commercial bank deposit rate caused by the increase in the capital adequacy ratio of commercial banks, has the effect of reducing the WACC of the NBFI sector as households substitute towards NBFI equity.

As discussed previously, commercial banks also reduce their supply of loan financing, as shown in Figure 3, via a reduction in the commercial bank exposure to risky financial assets, e.g., industry and reproducible housing loans (see also Figure 4). This increases the rate of return on industry and reproducible housing loans, which make up 4.8 per cent (industry loans) and 14.4 per cent (reproducible housing loans) of the financial assets owned by the $\mathrm{NBFI}$ sector. As the rate of return on the industry and reproducible housing loans rise, the $\mathrm{NBFI}$ agent purchases more of these assets (Figure 9). In USAGE2F, a balance sheet constraint is imposed upon the NBFI sector, linking the change in new assets acquired by the NBFI sector to the change in new liabilities issued by the sector. The expansion in the asset purchase activity of the NBFI agent is therefore funded via an expansion in the financial liabilities of the NBFI sector (Figure 10). ${ }^{10}$ This expansion in loan financing more than offsets the contraction in loan finance provision by commercial banks to the reproducible and non-reproducible housing agents. In part, this is a result of the large share (13.8\%) of U.S. commercial bank financial assets held as deposits at the U.S. Federal Reserve. If we also take account of U.S. government bonds held as financial assets by the U.S. commercial banks (which comprise $6 \%$ of the

\footnotetext{
${ }^{8}$ The US Federal Housing Finance Authority (FHFA) oversees Fannie Mae and Freddie Mac; their purchase of US mortgages is regulated by maximum loan limit criteria set by the FHFA. A loan that conforms to the FHFA limits is called a conforming loan, and GSE's can subsequently purchase conforming loans that have been originated by a US commercial bank. This removes the conforming financial asset from the balance sheet of the commercial bank.

${ }^{9}$ As discussed in section 2.5.2.2, in the USAGE2F financial database the NBFI agent includes the GSE's, together with money market mutual funds, finance companies, holding companies, and real estate investment trusts (REITs).

${ }^{10}$ Along similar lines to the assumed behaviour of the Banks, we assume that NBFI physical assets are unaffected. Hence, in Figure 10, the percentage deviation in financial assets lies above the percentage deviation in liabilities
} 
commercial banks aggregate financial assets), we observe that for each additional dollar of liabilities raised by U.S. commercial banks, approximately 80 cents are used to purchase risky financial assets, e.g., industry and reproducible housing loans. In contrast, $10 \%$ of the NBFI agents' aggregate financial assets are liabilities of the U.S. government and central bank, and thus a greater share of new financial liabilities raised by this agent (approximately 90 cents in every dollar) are devoted to risky financial asset purchases.

The increase in NBFl loans to reproducible housing couples with an increased appetite for reproducible housing equity by households, which accounts for 21.2 per cent of the reproducible housing financing requirements. These two effects therefore result in a small reduction in the WACC of reproducible housing, as shown in Figure 6. As the WACC of reproducible housing falls in response to the rise in the capital adequacy requirements of the Banks, gross fixed capital formation for housing investment experiences a small increase, as shown in Figure 11.

Industry loan financing is largely provided by the commercial banking sector (50.7 per cent), with a smaller (27.1 per cent) proportion of industry loan finance supplied by the NBFI's and the foreign investor ( 17.0 per cent). This contrasts with the reproducible housing sector, which as discussed above is majority NBFI-financed. The contraction in loan finance provision by the commercial banks therefore impacts the industry agent to a greater degree than the reproducible housing agent, which mutes the benefits experienced by the industry sector from the expansion in NBFI activity, relative to those realised by the reproducible housing sector. Nonetheless, 39.5 per cent of aggregate industry financial liabilities are equities held by households; the reduction in the commercial bank deposit rate increases household appetite for industry equity, reducing the rate of return on industry equity (Figure 12) and driving the industry WACC down relative to baseline (Figure 6). The reduction is however smaller in magnitude to that experienced by the reproducible housing agent, for the reasons discussed. As is clear from Figure 11, this drives a small rise in gross fixed capital formation for non-housing investment that trails the corresponding rise in gross fixed capital formation for housing investment. Nonetheless, with both components of aggregate investment slightly elevated relative to baseline, so too is aggregate investment, as shown in Figure 11.

With regard to the broader macroeconomic impacts of a rise in the capital adequacy requirements of the U.S. commercial banks, we recognise that the foreign financing share of the U.S. NBFI's (which makes up 16.9 per cent of total NBFI financial liabilities) exceeds that of the commercial banks ( 7.5 per cent of total liabilities). As previously discussed, the result of a rise in the capital adequacy ratio of the commercial banks reduces the financial asset budget of the banking sector (Figure 3), which is offset by a concurrent increase in the asset budget and loan finance provision by the NBFI's (Figure 10 and Figure 9). This is analogous to an autonomous increase in U.S. foreign financing; NBFI financing of the housing and non-housing sectors replaces commercial bank finance, driving up foreign financing and increasing foreign capital inflows to the U.S. For a given current account deficit, this results in nominal appreciation of the U.S. dollar, as shown in Figure 13.

As is clear from Figure 14, the balance sheets of the industry and reproducible housing sectors shift away from loan finance and towards equity finance. In the case of industry, bond finance also increases relative to baseline over the medium-to-long-term. This suggests an avenue via 
which the rise in the capital adequacy ratio potentially improves financial stability. Not only are commercial banks encouraged to finance a greater proportion of their operations by equity, but by raising the cost of bank debt finance, households are encouraged to finance a greater proportion of their stake in the reproducible housing sector via equity; similarly, industries are encouraged to finance a greater proportion of their gross fixed capital formation via equity and bonds.

Concerning the impact on the nominal exchange rate, nominal appreciation has the effect of reducing the US\$ price of imports, resulting in a small increase in U.S. import volumes (Figure 15). With the economy-wide nominal wage fixed in the year the capital adequacy ratio is increased, nominal appreciation of the currency drives the domestic price level down. This is evident in Figure 16, where we include a plot of the nominal wage and the domestic price level. With the aggregate price of domestic production falling and the nominal wage fixed in the event-year, a corresponding rise in the real producer wage occurs in the event-year. With physical capital stocks sticky and a rising real producer wage, a rise in capital adequacy of commercial banks reduces event-year employment, as shown in Figure 17.

As discussed in section 2.4, the interest rate that the central bank offers on settlement balance deposits by commercial banks (and the rate the central bank charges commercial banks for settlement balance loans) are each determined by a policy rule, in which the central bank policy rate responds to deviations in prices and unemployment from target. The fall in event-year employment, coupled with a fall in the private consumption deflator (also included in Figure 17), account for the initial negative deviation in the domestic policy rate shown in Figure 18. The movements in the policy rate reported in Figure 18 are small: a 0.44 basis point reduction in the year the policy is implemented, with this rising to a +0.8 basis point positive deviation by the end of the simulation period. This is very close to the central bank simply maintaining its baseline path for the policy rate.

As the nominal wage responds to the reduced level of event-year employment, and the domestic capital stock adjusts to shifts in domestic investment, the employment rate adjusts in turn; by the end of the simulation period, the employment rate has returned to baseline, while the private consumption deflator remains slightly elevated. This latter observation accounts for the positive deviation in the policy rate relative to baseline at the end of the simulation period (see Figure 18). To put these numbers in context, the recent U.S. Federal Reserve adjustment in the policy rate was a rise of 25 basis points. The deviation in the policy rate at the end of the period is 0.8 basis points. The positive deviation in the consumption price index at the end of the simulation period is approximately 0.004 per cent. This is akin to a realised inflation outcome of 2.004 per cent when the target is 2.0 per cent.

Figure 19 reports deviations in real GDP, employment, capital, and investment. As previously discussed, in the simulation's first year, the physical capital stock cannot change from baseline. However a small negative employment deviation in the simulation's first year generates a small negative deviation in real GDP in that year. Thereafter, employment increases before gradually returning to baseline. The aforementioned positive deviation in real investment causes the aggregate capital stock to rise relative to baseline over the medium-to-long-term (Figure 19). These effects drive a small positive deviation in GDP in the medium-to-long-term, of the order of +0.002 per cent. 
Figure 20 reports real GDP, real GNE, and the components of real GNE (private and public consumption spending, and investment). The aforementioned rise in real aggregate investment and fall in real GDP in the event-year drive the balance of trade towards deficit, with imports rising as import prices fall and nominal appreciation driving a movement upwards along foreign demand curves for U.S. exports. This results in an upward movement in the terms of trade (Figure 15), and a movement in the balance of trade towards deficit.

With a movement in the balance of trade towards deficit, we expect real GNE to lie above the deviation in real GDP. This is confirmed in Figure 20, and is due to the positive deviation in real aggregate investment (discussed with reference to Figure 11) and a positive movement in real private consumption (due to a positive deviation in the terms of trade, as we shall discuss). As discussed with reference to Figure 19, the increase in the capital adequacy ratio causes commercial bank lending to industry and housing to fall relative to baseline; importantly, this is offset by increases in equity finance provision by households, and loan finance supplied by NBFI's (see Figure 14). As shown in Figure 20, the resulting rise in dwelling and non-dwelling investment causes the aggregate investment deviation to lie above the real GDP deviation. This contributes to the GNE deviation lying above the real GDP deviation.

Similarly, we see in Figure 20 that the deviation in real private consumption spending lies above the real GDP deviation, thus also contributing to the GNE deviation lying above the real GDP deviation. This is because of the rise in the terms of trade, shown in Figure 15. In modelling consumption, we assume that nominal private consumption spending is a fixed proportion of nominal national income. Under this specification, a rise in the terms of trade increases private consumption spending relative to real GDP. While real public consumption spending is assumed to remain unchanged from baseline, this is insufficient to offset the contributions to the gap between the GNE and GDP deviations made by the increase in real investment and real private consumption spending.

\subsection{The macroeconomic impacts of financial structure differences: Comparing the}

\section{impacts of financial regulation in Australia and the United States}

Our description of the key drivers in the macroeconomic outcomes for the U.S. economy of a 100 basis point rise in the capital adequacy ratio of the U.S. commercial banks is largely driven by the ownership shares of other U.S. financial agents. For example, the large proportion of commercial bank deposits held by households in the U.S. drives a rebalancing of the household agent's financial asset portfolio; this is caused by a fall in the relative rate of return on commercial bank deposits, as commercial banks reduce their demand for deposit financing and substitute towards equity financing. However, with a large share of NBFI- and industryagent equity owned by households in the U.S., this rebalancing reduces the cost of equity finance to the NBFI's and industry agents. With cheaper financing available, the activity of each agent expands slightly. This has a direct effect on non-housing investment, because the WACC of the industry agent falls. Housing investment also rises however, because a large proportion of reproducible housing financing needs are met by NBFI's (42.5 per cent) and households (21.5 per cent) in the U.S. This drives a slight increase in the U.S. capital stock in the long-run, which drives real GDP higher. 
In contrast, recent work by Giesecke et al. (2016) found that a 100 basis point rise in the capital adequacy ratio of Australian commercial banks has a small, negative impact on real investment and real GDP in Australia. With regard to the real-side of the Australian FCGE model applied in Giesecke et al. (2016), its genesis is broadly in line with the USAGE2F model applied herein; see Dixon and Rimmer (2002) for a detailed description. Contrary to the findings presented herein for the U.S., Giesecke et al. (2016) find that the reduction in Australian commercial bank financing of industry and reproducible housing activity (resulting from the 100 basis rise in the capital adequacy ratio) drives real investment lower. While these agents can substitute towards other sources of financial capital, their ability to do so in Australia is constrained relative to the U.S., as we now describe.

For housing investment, approximately one half of the Australian sector's capital formation is financed by bank lending, with another one third financed via household equity. Outside of housing, bank financing accounts for approximately one quarter of the capital required to finance investment, with other sources like foreign markets and domestic superannuation satisfying, respectively, approximately one third and one tenth of non-housing investment financing needs. The higher dependency on bank financing of investment activity in Australia drives aggregate investment down in the short-run, impacting gross fixed capital formation and ultimately long-run real GDP.

The question that naturally arises when comparing the Australian and U.S. FCGE results of equivalent increases in the capital adequacy ratios of domestic commercial banks, is whether the differences are driven by the financial structure of the respective economies, or are matters related to the real-side of the economy (e.g., differences in primary factor substitution elasticities, export demand elasticities, or the sensitivity of investment to changes in rates of return), the dominant explanation? In what follows, we explore both avenues. Section 3.4.1 outlines our approach, while we present and describe our findings in section 3.5.1.

\subsubsection{Key structural differences between the United States and Australia}

We study four key structural differences between Australia and the United States, which could either in isolation or in combination drive contrasting responses to a 100 basis point rise in the capital adequacy ratio of the respective economies' commercial banks.

\subsubsection{Real-side differences}

Firstly, three key macroeconomic differences were identified:

1. The sensitivity of movements in real investment to movements in rates of return in USAGE2F differ slightly from the values specified for Australia in Giesecke et al. (2016);

2. The primary-factor-input substitution elasticity for industries in USAGE2F are slightly more inelastic than their corresponding values for the Australian FCGE model in Giesecke et al. (2016);

3. As a model of a larger open economy, export demand elasticities in USAGE2F are lower than the corresponding values for the Australian model applied in Giesecke et al. (2016). 
Herein, we explore the role each of the three structural differences outlined above have in driving differences between the deviation paths of key macroeconomic variables, e.g., real GDP, real investment, physical capital and employment, in response to a 100 basis point rise in the capital adequacy ratio.

\subsubsection{Differences in financial structure}

We also consider differences in the financial structure of the Australian and United States economies.

This is achieved by changing the structure of the USAGE2F financial database to more closely resemble the structure of the Australian financial economy, while maintaining values for aggregate stocks and flows. Put simply, we make the U.S. financial system look like the Australian system. For example, rather than 21.5 per cent and 12.4 per cent of household financial assets being invested in industry and NBFI equities respectively, we adjust these shares in the USAGE2F financial database to more closely resemble their Australianequivalent values of 9.3 per cent and 2.5 per cent respectively. This rebalancing is performed across the various financial asset agent/financial instrument/financial liability agent combinations, using a bi-proportional scaling algorithm.

The match is not exact, however; in the aforementioned example, the modified USAGE2F database shares are 12.4 per cent and 3.3 per cent respectively. This is because some relativities must be maintained within the USAGE2F financial database, e.g., the U.S. current account deficit in the USAGE2F financial database cannot be adjusted to match the corresponding value for Australia. Such an adjustment would disregard important linkages between the real-side CGE model and the financial theory, such as those discussed in section 2.1, which must be maintained. This places some limits on how far the structure of the U.S. financial sector can be adjusted to look like the Australian structure.

To describe some important differences between the USAGE2F shares and the Australian database shares, we use Figure 21 (USAGE2F financial database) and Figure 22 (Australian financial database), which summarise the proportion of each respective financial agents' liabilities that are owned by other financial agents in the model. In preparing these figures, we have summed over the types of financial liabilities owned by these financial agents, i.e., we have condensed the financial instrument dimension in Figure 21 and Figure 22. Some differences are immediately apparent; for example, from Figure 21 we observe that the reproducible housing sector in the U.S. sources 18.0 per cent of its financing needs from the commercial banks, whilst Figure 22 informs us that the Australian reproducible housing sector is majority (51.8 per cent) commercial bank financed. This is also emphasised in Table 8 , where we show the ownership shares of loans to reproducible housing in the USAGE2F and Australian FCGE model financial databases.

In both the U.S. and Australia, the majority of reproducible housing sector financing is via loans (62.7 per cent for the U.S. versus 65.6 per cent for Australia). From Table 8, we see that the vast majority of these loans sit on the balance sheet of the commercial banks in Australia (75.8 per cent), with a much smaller proportion being financial assets of Australian NBFI's (18.2 per cent). The roles of these agents in the U.S. are essentially reversed, with 
67.7 per cent of loans to reproducible housing in the U.S. provided by the NBFI's and 28.7 per cent provided by U.S. commercial banks. The NBFI's therefore play a smaller role in funding housing investment in Australia relative to the United States; this is also evident upon comparison of Figure 21 and Figure 22, which show that 42.5 per cent of the aggregate financial liabilities of the reproducible housing sector in the U.S. are financial assets of the NBFI's, as opposed to 12.5 per cent in the Australia.

The simulation results presented in section 3.3 highlighted that U.S. households provide a large share of the NBFI agents financing requirements, in particular, via ownership of NBFI equity liabilities. As the capital adequacy ratio of commercial banks was increased and the rate of return on commercial bank deposits fell, the household rebalanced their asset portfolio away from commercial bank deposits (which make up 12.3 per cent of U.S. household financial assets versus 13.3 per cent for Australian households) and towards other financial assets. In the U.S., this rebalancing includes a sizeable allocation to industry and NBFI equity, which make up 21.5 per cent and 12.4 per cent of U.S. household financial assets respectively. The proportion of household ownership of industry and NBFI equity is much smaller in Australia; 9.3 per cent of the household portfolio is allocated to industry equity, and 2.5 per cent is allocated to NBFI equity. These proportions represent 18.8 per cent and 11.8 per cent of the financing requirements of these two agents, respectively, compared to 39.5 per cent and 30.8 per cent in the U.S.

In contrast to their U.S. counterparts, Australian industry is also much more reliant on commercial bank financing (22.7 per cent financial liability ownership share in Australia compared to 5.7 per cent in the U.S., which is highlighted in Figure 21 and Figure 22), with a larger share of financing provided by the foreign investor in Australia ( 33.5 per cent versus 19.8 per cent) and a smaller share provided by the Australian NBFI's (8.4 per cent versus 16.4 per cent).

Australian NBFI's are also more dependent upon Australian commercial banks themselves; Australian commercial banks own 22.7 per cent of the aggregate financial liabilities issued by NBFI's (commercial banks own the largest proportion of NBFI liabilities when compared with the other Australian financial agents), almost double the ownership share (11.7 per cent) in the U.S. (see Figure 21 and Figure 22).

In section 3.5, we outline the methodology we use to describe the differences between the USAGE2F and Australian FCGE model results. Our analysis uses some of the shares discussed in this section to describe key differences between the two sets of results, and is provided in section 3.5.1.

\subsection{Methodology and Analysis}

In this section, we study the impact of these four key structural differences and their relative importance in driving the USAGE2F simulation results, relative to those for Australia presented in Giesecke et al. (2016). This focuses on a series of decomposition figures. The decomposition figures are created by running the USAGE2F FCGE model five times, with each model run subject to the same 100 basis point increase in the capital adequacy ratio of the commercial banks: 
1. One simulation using the current USAGE2F elasticity and financial database specifications;

2. A second run, where we adjust the elasticity of investment with respect to movements in rates of return on capital in USAGE2F to match their Australian FCGE model equivalents;

3. A third run, adjusting the primary-factor-substitution elasticity to the Australian model values;

4. A fourth run, where the USAGE2F financial database is adjusted following the process outlined in section 3.4.1;

5. A final run, where we adjust the export demand elasticities to match the Australian export demand elasticities.

We then study the impact of the deviations between the Australian and USAGE2F FCGE model results, as the four key structural differences are adjusted one-by-one from their standard USAGE2F specifications, to Australian specifications. A residual item is also included, which captures differences beyond the four structural differences outlined.

\subsubsection{Decomposing the differences between Australia and the United States}

In this section, we study the similarities and differences between the USAGE2F and Australian FCGE model simulation results in Giesecke et al. (2016), when each model is used to study a 100 basis point increase in the commercial bank capital adequacy ratio.

While the magnitudes of the deviations from baseline differ slightly, some implications of the rise in the capital adequacy ratio of commercial banks are similar whether one considers the USAGE2F or Australian FCGE model. For example, as described for USAGE2F and shown in Figure 2, commercial banks increase the issuance of equity and reduce their reliance on deposit and bond financing in each model. Additionally, both U.S. and Australian commercial banks reduce their holding of risky assets, as shown in Figure 3 for the U.S., whilst also reducing the size of their financial asset portfolio. These movements have similar implications for the rate of return on commercial bank equity, which rises in both Australia and the U.S., whilst the rates of return on commercial bank deposits also fall in both cases. For brevity, we omit decomposition diagrams highlighting these movements.

Proceeding as outlined in section 3.5, we first considered the differences that arise between the deviation of real aggregate investment from baseline, as realised in USAGE2F and the Australian FCGE models (Figure 23). Figure 23 can be read in the following way: the solid black line is the percentage deviation from baseline for real aggregate investment in USAGE2F, whereas the dotted black line is the Australian FCGE model result. The purple bar is the impact on the USAGE2F deviation from baseline (i.e., the solid black line) when we adjust the sensitivity of investment to changes in rate of return on capital in USAGE2F, to match the Australian FCGE model specifications. That is, the USAGE2F model with the Australian investment sensitivity yields a result for real investment equal to the solid black line, plus the purple bars in Figure 23. As shown in Figure 23, the impact of the revised investment sensitivity is small, with real aggregate investment adjusted upwards (and therefore further away from the Australian FCGE model deviation from baseline in the year of the shock). The remaining solid bars represent the impact on the USAGE2F result as we 
progressively alter the primary factor substitution elasticity (red bars), financial database shares (green bars), export demand elasticity (orange bars) and other effects (blue bars). The sum of the coloured bars yields the overall deviation between the USAGE2F and Australian FCGE model results.

Importantly, as shown in Figure 23, the deviation between the USAGE2F result for real investment and the Australian FCGE model result can be overwhelmingly attributed to the financial database shares. This is because the database shares are critical in determining movements in the WACC of both the reproducible housing and industry agents; decomposition diagrams for the WACC of these agents are shown in Figure 24 and Figure 25 respectively. In USAGE2F the WACC for each agent falls, which in turn stimulates housing and non-housing investment (see Figure 11). As shown in Figure 24 and Figure 25, the impact of the financial database shares (green bars) on the WACC of each agent is large and positive, i.e., modifying the USAGE2F financial database shares to more closely match the Australian shares increases the WACC relative to baseline for both agents, ceteris paribus. The financial shares are also shown to drive the large majority of the differences between the USAGE2F and Australian FCGE model results. In what follows, we use our analysis of the two respective financial databases and their ownership shares from section 3.4.3 to explain this result.

Firstly, when the commercial bank capital adequacy ratio is increased in the U.S., the fall in the WACC for the reproducible housing sector is driven by an increased appetite for reproducible housing loans by the NBFI sector. As discussed in section 3.4.3, the NBFI sector finances 67.7 per cent of loans to reproducible housing in the U.S. In contrast, 28.7 per cent of reproducible housing loans are provided by U.S. commercial banks. The NBFI sector can increase lending to reproducible housing, because as discussed in section 3.3, the household sector's appetite for NBFI equities increases as they rebalance their financial asset portfolio in response to a fall in the rate of return on commercial bank deposits. With a large share of the household asset portfolio invested in NBFI equity (12.4 per cent, making up 30.8 per cent of aggregate NBFI financial liabilities), this increase in supply of equity financing to NBFI's drives down the rate of return on NBFI equity, lowering the weighted average cost of NBFI financial capital.

As discussed in section 3.4.3, in Australia the roles of the NBFI and commercial banking agents are essentially reversed; the majority of reproducible housing loans sit on the balance sheet of the commercial banks (75.8 per cent), with a much smaller proportion being financial assets of Australian NBFI's (18.2 per cent). Therefore, whilst the reproducible housing agent can substitute towards other sources of financial capital, their ability to do so is constrained relative to the U.S., because the majority of reproducible housing finance is sourced from the commercial banks in Australia, as shown in Figure 22. As such, the reductions in commercial bank lending caused by the rise in the capital adequacy ratio, drives an increase in the WACC of the Australian reproducible housing agent (Figure 24).

Australian industry is also more dependent on commercial bank financing than their U.S. counterparts, as discussed in section 3.4.3; the proportion of aggregate industry financial liabilities owned by Australian commercial banks in Australia is 22.7 per cent, compared to 5.7 per cent in the U.S. (see Figure 21 and Figure 22). The capacity of Australian industry to 
substitute for other funding sources is therefore also constrained relative to their U.S. counterparts, however less so than the reproducible housing agent. This is because the commercial bank ownership share of Australian industry financial liabilities (22.7 per cent) is lower than the share for the reproducible housing sector (51.8 per cent).

In summary, differences in the ownership shares of industry and reproducible housing financial liabilities between financial agents in Australia and the U.S., alter the direction of the deviation in real investment from baseline, when the capital adequacy ratio of commercial banks in each country are increased by 100 basis points.

With real investment falling in Australia and increasing in the U.S. relative to baseline, we expect movements in the physical capital stock between USAGE2F and the Australian FCGE model to also differ. This discrepancy is highlighted in Figure 26; unsurprisingly, with a large proportion of the difference in real investment between the results from each model driven by the financial database shares (see the green bars in Figure 23), we find the majority of the deviation between the results for physical capital is also driven by the financial database shares. With nominal wage adjustment driving long-term employment back to baseline in each model, i.e., the result for employment is proportionately driven by differences in the financial database shares and other structural differences between Australia and the U.S. in the long-run (see the decomposition diagram for employment in Figure 27), the difference in the physical capital outcome for each model drives a difference in real GDP growth relative to baseline (Figure 28). As expected, because this is a result of a fall (rise) in the physical capital stock of Australia (the U.S.), the deviation in real GDP growth in response to the rise in commercial bank capital adequacy is also largely due to differences in the financial structure between the two countries (green bars).

Similar conclusions can be drawn for other key macro variables using decomposition diagrams; however for brevity we omit such diagrams. The results presented establish the importance of the financial structure of Australia and the U.S., particularly with regard to the macroeconomic implications of changes in the capital adequacy of domestic commercial banks. Importantly, we find that while differences do arise between Australia and the U.S., the overall macroeconomic impact in each country of a 100 basis point rise in the capital adequacy ratio of commercial banks is small.

\section{Concluding remarks and future work}

Following the widespread economic impact of the global financial crisis, a cornerstone principal of the Basel III capital framework released in December 2010 was a significant increase in the minimum capital requirements of commercial banks [Natter (2012)]. Along these lines, recent work by Giesecke et al. (2016) explored the impact of a 100 basis point increase in the capital adequacy ratio of commercial banks in Australia. Giesecke et al. (2016) showed that such a rise in capital adequacy requirements have modest macroeconomic impacts in Australia, while securing a rise in bank capital, a shift in bank lending away from residential housing investment, a rise in household equity financing of home ownership, and a rise in equity and bond financing of capital formation by industry. 
In this article, we have explored the impact of an equivalent shock to the capital adequacy ratio of U.S. commercial banks. This is achieved via the development of a financial CGE model of the U.S. economy, called USAGE2F. As in Giesecke et al. (2016), we find the macroeconomic impacts of a 100 basis point rise in the capital adequacy ratio of the commercial banks are small, but differ in important ways from the results in Giesecke et al. (2016) for Australia. Using decomposition diagrams, we elucidate the source of these differences as resulting from dissimilarities in the financial structure of the U.S. economy, compared with Australia. In a relative sense, differences between the real-side economies in the two nations are shown to have a less significant influence.

In future work, we plan to extend the modelling reported in this paper in two main directions. First, as discussed in section 2.3.2, we modelled the U.S. commercial bank along similar lines to that outlined in Giesecke et al. (2016). The regulatory framework and risk weights in USAGE2F are therefore adopted from previous work for Australia. In outlining the impact on the U.S. economy of an increase in the capital adequacy ratio of the U.S. commercial banks outlined in section 3.3, we are cognisant that differences in the U.S. regulatory regime may alter the overall macroeconomic outcome of the policy studied herein. Nevertheless, as discussed in section 3.3 and in this conclusion, the macroeconomic impacts of more stringent capital adequacy requirements are shown to be small. While the direction of the deviation from baseline in certain variables may therefore change under a revised regulatory framework, e.g., real investment may reasonably be anticipated to fall under some circumstances, the magnitude of the deviations from baseline are not expected to change materially.

Second, the Dodd-Frank Wall Street Reform and Consumer Protection Act (DFA) provides a mandate for the U.S. Federal Reserve Board to declare some non-bank financial institutions as non-bank systematically important financial institutions. These institutions are subject to strict prudential regulatory standards and supervision by the Federal Reserve Board (FRB). For example, GE Capital, along with a number of securities dealers and brokers, are listed as nonbank SIFI's under DFA. With regard to GE Capital, on July 202015 the FRB published a final order $^{11}$ applying enhanced prudential standards in two phases: the first phase (effective January 2016) and a second phase (effective January 2018). As highlighted in Table 2, GE Capital is classified as a finance company is the FRSR0615 data, while the financial assets and liabilities of security dealers and brokers are also segregated from other non-bank financial institutions. We hope to explore the impact on our findings of a disaggregated non-bank SIFI agent, who would operate under similar capital adequacy requirements to the commercial banks in the U.S.

Such a disaggregation may naturally be extended to include GSE's and other agency-backed security issuers, together with theory aimed at accounting for residential mortgages of different quality (or some proxy of the category one and category two classifications for residential mortgages adopted in U.S. Basel III regulations, as described in Natter (2012)). This would allow for a more accurate specification of commercial bank and non-bank SIFl's risk weighted asset positions.

${ }^{11}$ See https://www.federalreserve.gov/aboutthefed/boardmeetings/board-memo-gecc-20150720.pdf 


\section{References}

[Adams (2007)]

[BEA (2014)]

[Bernanke and Blinder (1988)]
Adams, P. D. (2007). Insurance against catastrophic climate change: How much will an emissions trading scheme cost Australia? Australian Economic Review 40(4), 432-452.

BEA, U. D. o. C. (2014). Chapter IV: Relationship to Other Economic Accounts. In U.S. International Economic Accounts: Concepts \& Methods, pp. 4.1-- 4.2. Bureau of Economic Analysis, U.S.A.

Bernanke, B. S. and A. S. Blinder (1988). Is it money or credit, or both, or neither. In Papers and proceedings of the one-hundredth Annual Meeting of the American Economic Association, Volume 78, pp. 435-439.

[Board of Governors of The Federal Reserve System Statistical Release Z.1. (2015)]

Board of Governors of The Federal Reserve System Statistical Release Z.1. (Q2 2015). Financial Accounts of the United States Flow of Funds, Balance Sheets, and Integrated Macroeconomic Accounts. Technical report.

[Commonwealth of Australia (2014)]

Commonwealth of Australia (2014). Financial System Inquiry Final Report. Number November.

[Dixon and Rimmer (2002)]

Dixon, P. and M. Rimmer (2002). Dynamic general equilibrium modelling for forecasting and policy. A practical guide and documentation of Monash. Elsevier.

[Dixon et al. (2015)]

Dixon, P. B., J. A. Giesecke, and M. T. Rimmer (2015). Superannuation Within a Financial CGE Model of the Australian Economy.

[Dixon et al. (2011)]

Dixon, P. B., J. A. Giesecke, M. T. Rimmer, and A. Rose (2011). The Economic Costs to the U.S. of Closing its Borders: A Computable General Equilibrium Analysis. Defence and Peace Economics 22(1), 85-97.

[Dixon and Parmenter (1996)] Dixon, P. B. and B. Parmenter (1996). Computable general equilibrium modelling for forecasting and policy simulation. Handbook of Computational Economics 1, 1-85. 
[Dixon and Rimmer (2004)]

[Dixon and Rimmer (2009)]

[Dixon and Rimmer (2016)]

[Giesecke et al. (2015)]

[Giesecke et al. (2016)]

[Johansen (1960)]

[Kashyap and Stein (1994)]

[Lowe (1995)]

[Mishkin (1995)]

[Natter (2012)]

[Orphanides (2007)]

[Otto (2007)]
Dixon, P. B. and M. T. Rimmer (2004). The US economy from 1992 to 1998 : Results from a detailed CGE model. Economic Record 80(1), S13-S23.

Dixon, P. B. and M. T. Rimmer (2009). Restriction or Legalization? Measuring the Economic Benefits of Immigration Reform. Center for Trade Policy Studies 40, 40.

Dixon, P. B. and M. T. Rimmer (2016). Johansen's legacy to CGE modelling: Originator and guiding light for 50 years. Journal of Policy Modelling.

Giesecke, J. A., W. Burns, A. Rose, T. Barrett, and M. Griffith (2015). Regional Dynamics Under Adverse Physical and Behavioral Shocks: The Economic Consequences of a Chlorine Terrorist Attack in the Los Angeles Financial District. In Regional Science Matters, Volume 732, Chapter 16, pp. 319-350. Springer International Publishing.

Giesecke, J. A., P. B. Dixon, and M. T. Rimmer (2016). The economy-wide impacts of a rise in commercial bank capital adequacy ratios.

Johansen, L. (1960). A multi-sectoral study of economic growth. Amsterdam: North-Holland Publishing Company.

Kashyap, A. and J. Stein (1994). Monetary policy and bank lending. In N. Mankiw (Ed.), Monetary Policy, pp. Ch. 7. University of Chicago Press.

Lowe, P. (1995). The link between the cash rate and market interest rates. Technical report, Reserve Bank of Australia.

Mishkin, F. S. (1995). Symposium on the monetary transmission mechanism. Journal of Economic Perspectives 9(4), 3-10.

Natter, R. (2012). Mortgage Finance under Basel III. Technical report, Barnett Sivon and Natter, P.C.

Orphanides, A. (2007). Taylor Rules. Divisions of Research \& Statistics and Monetary Affairs, Federal Reserve Board Finance and Economics Discussion Series Working Pa.

Otto, G. (2007). Central bank operating procedures: how the RBA achieves its target for the cash rate. The Australian Economic Review 40(2), 216-224. 
[Taylor (1993)]

[Wittwer and Dixon (2015)]

[Woodford (2001)]

[Woodford (2003)]
Taylor, J. B. (1993). Discretion versus policy rules in practice. Carnegie-Rochester Conference Series on Public Policy 39(December), 195-214.

Wittwer, G. and J. Dixon (2015). The Labour Module in a Dynamic Regional CGE Model and.

Woodford, M. (2001). Monetary policy in the information economy. Technical report, Paper prepared for the "Symposium on Economic Policy for the Information Economy", Federal Reserve Bank of Kansas City.

Woodford, M. (2003). Interest and prices: foundations of a theory of monetary policy. Princeton University Press. 


\section{Tables}

Table 1: Risk weights on commercial bank assets

\begin{tabular}{|c|c|c|}
\hline Parameter & Description & Value $^{(a)}$ \\
\hline $\operatorname{RISKWGT}_{(\mathrm{CB}, \mathrm{f})}(\forall \mathrm{f} \in \mathrm{FI})$ & Liabilities issued by the Central Bank. & 0 \\
\hline $\operatorname{RISKWGT}_{(\text {Govt,f) }}(\forall \mathrm{f} \in \mathrm{FI})$ & Liabilities issued by the domestic government. & 0 \\
\hline $\operatorname{RISKWGT}_{(s, \text { Cash) }}(\forall \mathrm{s} \in \mathrm{LA})$ & Cash. & 0 \\
\hline $\operatorname{RISKWGT}_{(s, \text { Equity) }}(\forall \mathrm{s} \in \mathrm{LA})$ & Equity. & 3.0 \\
\hline RISKWGT (Foreigners, DeposLoans) $_{\text {) }}$ & Loans to foreign agents. & 0.4 \\
\hline RISKWGT (Inds, DeposLoans) $_{\text {. }}$ & Loans to domestic industry. & 0.4 \\
\hline RISKWGT (NonBankFinln,DeposLoans) $_{\text {( }}$ & Loans to non-bank financial intermediaries. & 0.4 \\
\hline RISKWGT $_{\text {(NRH,DeposLoans) }}$ & Loans to the non-reproducible housing sector. & 0.35 \\
\hline RISKWGT (RH,DeposLoans) $_{\text {(S) }}$ & Loans to the reproducible housing sector. & 0.5 \\
\hline RISKWGT (NonBankFinln,Bonds) $_{1}$ & $\begin{array}{l}\text { Bonds issued by non-bank financial } \\
\text { institutions. }\end{array}$ & 0.4 \\
\hline RISKWGT $_{\text {(Foreigners,Bonds) }}$ & Foreign bonds. & 0.4 \\
\hline \multicolumn{3}{|c|}{$\begin{array}{l}\text { (a) In choosing values for RISKWGT, we were guided by Giesecke et al. (2016). Independent } \\
\text { evaluation of key risk weights for U.S. residential mortgages confirmed the weights summarised } \\
\text { above for Australia as being suitable (see Natter (2012)), while the assumption of an equity-like } \\
\text { risk on GSE securities is also conservative (see also Natter (2012)). }\end{array}$} \\
\hline
\end{tabular}


Table 2: Summary list of FRSR062015 financial asset and liability agents

\begin{tabular}{|c|c|c|}
\hline $\begin{array}{l}\text { FRSR0615 } \\
\text { Classification }\end{array}$ & $\begin{array}{l}\text { FRSR0615 } \\
\text { Numeric } \\
\text { Classification }\end{array}$ & Description \\
\hline \multicolumn{3}{|r|}{ Asset and Liability Agents } \\
\hline HHoldsNFP & 101 & $\begin{array}{l}\text { Households and Not-for-Profit Organisations. Derived largely } \\
\text { as a residual item to the accounts, and therefore contains } \\
\text { financial assets/liabilities of Domestic Hedge Funds and } \\
\text { Private Equity Firms, as well as not-for-profit organisations. }\end{array}$ \\
\hline NonFinCorp & 103 & $\begin{array}{l}\text { Nonfinancial Corporate Businesses. No access to Corporate } \\
\text { Equity markets to fund business activities, however does not } \\
\text { trade in financial services. }\end{array}$ \\
\hline NonFinNoCorp & 104 & $\begin{array}{l}\text { Nonfinancial Noncorporate Businesses. Small businesses that } \\
\text { trade in similar goods and service to nonfinancial corporate } \\
\text { businesses. All equity is owned by the households. }\end{array}$ \\
\hline FedGov & 106 & Federal Government. \\
\hline SLGov & 107 & State and Local Government. \\
\hline FedReserve & 109 & The Monetary Authority. \\
\hline PrivDeposIns & 110 & $\begin{array}{l}\text { Private Depository Institutions, comprising U. S.-Chartered } \\
\text { Depository Institutions, Foreign Banking Offices in the U. S., } \\
\text { Banks in U. S.-Affiliated Areas and Credit Unions. }\end{array}$ \\
\hline Insurers & $115+116$ & $\begin{array}{l}\text { Insurers, including Property-Casualty Insurance and Life } \\
\text { Insurance Organisations. }\end{array}$ \\
\hline DBFunds & $\begin{array}{c}118 b+119 b+ \\
120 b\end{array}$ & $\begin{array}{l}\text { Defined Benefit Superannuation Funds, spanning the Private, } \\
\text { Federal and State and Local Government superannuation } \\
\text { sectors. The individual sectors can be disaggregated if } \\
\text { required. }\end{array}$ \\
\hline DCFunds & $\begin{array}{c}118 c+119 c+ \\
120 c\end{array}$ & $\begin{array}{l}\text { Defined Contribution Superannuation Funds, spanning the } \\
\text { Private, Federal and State and Local Government } \\
\text { superannuation sectors. }\end{array}$ \\
\hline MoneyMktMFds & 121 & $\begin{array}{l}\text { Money Market Mutual Funds. Represent the set of domestic } \\
\text { fund managers who operate in the Fixed Income space only; } \\
\text { they do not trade in equity markets. Represented as a large } \\
\text { unit trust, with the sum of financial assets matching the sum } \\
\text { or liabilities on issue. A pure financial agent who is valued at } \\
\text { market. }\end{array}$ \\
\hline MutualFds & 122 & $\begin{array}{l}\text { Mutual Funds. Represent the set of domestic fund managers } \\
\text { who operate in both the Fixed Income and Equity space. } \\
\text { Represented as a large unit trust, with the sum of financial } \\
\text { assets matching the sum or liabilities on issue. A pure financial } \\
\text { agent who is valued at market. }\end{array}$ \\
\hline ETFs & 123 & $\begin{array}{l}\text { Exchange-Traded and Closed-Ended Funds. The set of mutual } \\
\text { funds who are closed to new business, together with the set } \\
\text { of all Exchange Traded Fund managers, e.g., iShares, } \\
\text { Vanguard, etc. }\end{array}$ \\
\hline GSES & 124 & $\begin{array}{l}\text { Government Sponsored Enterprises, spanning Fannie Mae, } \\
\text { Freddie Mac, Farmer Mac, Federal Home Loan Banks, the } \\
\text { Farm Credit System, the Financing Corporation and the } \\
\text { Resolution Funding Corporation. }\end{array}$ \\
\hline
\end{tabular}




\begin{tabular}{|c|c|c|}
\hline $\begin{array}{l}\text { FRSR0615 } \\
\text { Classification }\end{array}$ & $\begin{array}{l}\text { FRSR0615 } \\
\text { Numeric } \\
\text { Classification }\end{array}$ & Description \\
\hline GSEMortPools & 125 & Pools of Mortgage-Backed Securities created by the GSE's \\
\hline ABSIssuers & 126 & $\begin{array}{l}\text { Asset-Backed security Issuers. Issue short-dated commercial } \\
\text { paper and corporate bonds backed by mortgages or loans } \\
\text { over assets, e.g., home, commercial and farm loans, credit } \\
\text { card or automobile debt, trade credits or other asset backed } \\
\text { securities. }\end{array}$ \\
\hline FinanceComp & 127 & $\begin{array}{l}\text { Finance Companies. Corporations that provide financing } \\
\text { through the purchase of debt securities as financial assets, } \\
\text { e.g., General Electric's GE Capital, General Motor's GMAC. }\end{array}$ \\
\hline REITS & 128 & $\begin{array}{l}\text { Real Estate Investment Trusts. Corporations who trade in real } \\
\text { estate or real estate mortgages. Based on the Integrated } \\
\text { Accounts data, we infer that no significant residential real } \\
\text { estate is owned by REITs in the U.S., despite the FoF's data } \\
\text { implying multifamily (apartment building) fixed investment } \\
\text { being a component of annual REIT flow of funds. }\end{array}$ \\
\hline Brokers & 129 & $\begin{array}{l}\text { Brokers and Dealers. Market makers who facilitate the } \\
\text { transfer of physical securities or financial risk. Hold significant } \\
\text { proportions of security repurchase agreement as assets and } \\
\text { also liabilities, along with various other financial instruments. }\end{array}$ \\
\hline HoldingComp & 130 & $\begin{array}{l}\text { Holding Companies. Companies that own the outstanding } \\
\text { securities of other companies, and trade in no physical assets } \\
\text { directly. Activities funded through the issue of debt securities } \\
\text { and equity. }\end{array}$ \\
\hline FundingCorp & 131 & $\begin{array}{l}\text { Funding Corporations. Intermediaries that facilitate the } \\
\text { funding of financial or real economy activities, e.g., financial } \\
\text { bailouts or U. S. export funding. Large exposure to debt } \\
\text { securities as a means of financing their own activities and } \\
\text { facilitating those of other agents. }\end{array}$ \\
\hline Foreigner & 132 & $\begin{array}{l}\text { The Rest of the World. The foreign agent. FRSR0615 and } \\
\text { FRSR0915 assume no nonfinancial U. S. assets are held by the } \\
\text { foreigner. }\end{array}$ \\
\hline ResidentRE & Artificial Agent & $\begin{array}{l}\text { Sum of the total stock of US residential real estate, valued at } \\
\text { market. }\end{array}$ \\
\hline
\end{tabular}


Table 3: Financial Agents, USAGE2F Database

\begin{tabular}{|c|c|}
\hline $\begin{array}{l}\text { USAGE2F Handle } \\
\text { Agents }\end{array}$ & Description \\
\hline HIds & The Household Agent \\
\hline Inds & $\begin{array}{l}\text { Nonfinancial industries, } \\
\text { excluding housing }\end{array}$ \\
\hline Govt & The Government Agent \\
\hline $\mathrm{CB}$ & The Monetary Authority \\
\hline Banks & $\begin{array}{l}\text { Authorised Private } \\
\text { Depository Institutions }\end{array}$ \\
\hline Lifelns & $\begin{array}{l}\text { Property, Casualty and Life } \\
\text { Insurers }\end{array}$ \\
\hline Retire & $\begin{array}{l}\text { Retirement/Superannuation } \\
\text { Funds }\end{array}$ \\
\hline NBFI & $\begin{array}{l}\text { Financial Institutions } \\
\text { excluding the Banking Sector }\end{array}$ \\
\hline Fgn & The Foreign Agent \\
\hline $\mathrm{RH}$ & $\begin{array}{l}\text { Reproducible Housing, being } \\
\text { new apartments or property } \\
\text { in new housing estates. }\end{array}$ \\
\hline $\mathrm{NRH}$ & $\begin{array}{l}\text { All Residential Property not } \\
\text { classified as Reproducible. }\end{array}$ \\
\hline
\end{tabular}


Table 4: Mapping USAGE2F database agents to the FRSR0615 agents

\begin{tabular}{|c|c|}
\hline $\begin{array}{c}\text { FRSR0615 } \\
\text { Agents }\end{array}$ & $\begin{array}{c}\text { USAGE2F Database } \\
\text { Agents }\end{array}$ \\
\hline HHoldsNFP & Hlds \\
\hline NonFinCorp & Inds \\
\hline NonFinNoCorp & Inds \\
\hline FedGov & Govt \\
\hline SLGov & Govt \\
\hline FedReserve & CB \\
\hline PrivDeposIns & Banks \\
\hline Insurers & Lifelns \\
\hline DBFunds & Retire \\
\hline DCFunds & Retire \\
\hline MoneyMktMFds & NBFI \\
\hline MutualFds & NBFI \\
\hline ETFs & NBFI \\
\hline GSEs & NBFI \\
\hline GSEMortPools & NBFI \\
\hline ABSIssuers & NBFI \\
\hline FinanceComp & NBFI \\
\hline REITs & NBFI \\
\hline Brokers & NBFI \\
\hline HoldingComp & NBFI \\
\hline FundingCorp & NBFI \\
\hline Foreigner & Fgn \\
\hline ResidentRE & One-third to RH \\
\hline Two-thirds to NRH \\
\hline
\end{tabular}

Table 5: FRSR0615 database financial and nonfinancial instruments

\begin{tabular}{l|l|}
\multicolumn{1}{c|}{$\begin{array}{c}\text { FRSR0615 } \\
\text { Instruments }\end{array}$} & \multicolumn{1}{c|}{ Description } \\
\hline ABSecurities & $\begin{array}{l}\text { Broad aggregation of mortgage-, consumer- and trade-credit backed } \\
\text { securities that we classed as Asset-backed Securities. }\end{array}$ \\
\hline AutoLoan & Automotive Loans to Consumers. \\
\hline Bonds & Corporate and Municipal Bonds. \\
\hline CardDebt & Consumer Credit Card Debt. \\
\hline Cash & Cash, consisting of time and savings deposits and foreign cash deposits. \\
\hline ComPaper & $\begin{array}{l}\text { Commercial Paper, representing money market securities with short } \\
\text { terms to maturity (generally<1 year). }\end{array}$ \\
\hline ComPropLoan & Commercial Property Loans. \\
\hline Currency & Currency \\
\hline Equity & Corporate and Noncorporate equity. \\
\hline
\end{tabular}




\begin{tabular}{|c|c|}
\hline $\begin{array}{l}\text { FRSR0615 } \\
\text { Instruments }\end{array}$ & Description \\
\hline FarmLoan & Farm Loans that excludes the Farm House. \\
\hline FDIDebt & $\begin{array}{l}\text { Foreign Direct Investment (either US Abroad or Foreigner in the US) in } \\
\text { the form of Debt Finance. }\end{array}$ \\
\hline FDIEquity & $\begin{array}{l}\text { Foreign Direct Investment (either US Abroad or Foreigner in the US) in } \\
\text { the form of Equity Finance. }\end{array}$ \\
\hline HomeLoan & Home Loans. \\
\hline LifePenRes & $\begin{array}{l}\text { Reserves managed by Pension Funds and Life Insurers to meet future } \\
\text { liabilities. Also includes unallocated insurance company contracts and } \\
\text { pension fund contributions payable. }\end{array}$ \\
\hline Loans & $\begin{array}{l}\text { Loans that could not be classified into Consumer Credit, Mortgages or } \\
\text { Trade Credits. }\end{array}$ \\
\hline MultiFamLoan & Multi-family residential mortgages. \\
\hline NMTreasuries & Nonmarketable Treasury Securities. \\
\hline NoResidentRE & Non-residential buildings, including Hospitals and Schools. \\
\hline OvrNghtLoan & Overnight Loans for Settlement of Exchange Balances. \\
\hline Receivables & $\begin{array}{l}\text { Spans Trade and Security Credit, Taxes Payable and Receivable, and } \\
\text { transactions with subsidiaries (principally by Holding Companies). }\end{array}$ \\
\hline Repurps & $\begin{array}{l}\text { Repurchase agreements, which are essentially a loan from the asset } \\
\text { agent to the liability agent where collateral in the form of a debt security } \\
\text { is provided by the liability agent. }\end{array}$ \\
\hline Reserves & Reserves, placed with either the World Bank or the Monetary Authority \\
\hline RevRepurps & $\begin{array}{l}\text { Reverse Repurchase Agreements, which are a loan to the asset agent } \\
\text { from the liability agent, with the asset agent providing collateral in the } \\
\text { form of a financial instrument to secure the loan. }\end{array}$ \\
\hline SDR & Special Drawing Rights \\
\hline StudentLoan & Student Loans. \\
\hline TBills & Treasury short-duration bills of maturity less than 1 year. \\
\hline Treasuries & Treasury Bonds. \\
\hline USSavingsBnd & $\begin{array}{l}\text { Retail US Government securities called US Savings Bonds; marketed and } \\
\text { sold to Households, rather than the wholesale Treasury Bills and } \\
\text { Securities. }\end{array}$ \\
\hline
\end{tabular}


Table 6: Financial Instruments, USAGE2F database

\begin{tabular}{|c|l|}
\hline $\begin{array}{c}\text { USAGE2F Handle } \\
\text { Instrument }\end{array}$ & \multicolumn{1}{|c|}{ Description } \\
\hline Bonds & $\begin{array}{l}\text { Interest-bearing securities } \\
\text { that have varying terms to } \\
\text { maturity, and can be backed } \\
\text { or secured by physical assets. }\end{array}$ \\
\hline DepLoans & $\begin{array}{l}\text { Loans that may be secured } \\
\text { by a physical asset. }\end{array}$ \\
\hline Cash & $\begin{array}{l}\text { Cash; can be either } \\
\text { denominated in US\$ or } \\
\text { foreign currency }\end{array}$ \\
\hline GoldSDRs & $\begin{array}{l}\text { Gold (where a suitable } \\
\text { financial counterparty exists) } \\
\text { or Special Drawing Rights }\end{array}$ \\
\hline Equity & $\begin{array}{l}\text { Any claim that lies further } \\
\text { along the risk-return } \\
\text { spectrum when compared to } \\
\text { Bonds. }\end{array}$ \\
\hline
\end{tabular}

Table 7: Mapping FRSR0615 instruments to the USAGE2F database instruments

\begin{tabular}{|c|c|}
\hline $\begin{array}{l}\text { FRSR0615 } \\
\text { Instruments }\end{array}$ & USAGE2F Instrument \\
\hline ABSecurities & Equity \\
\hline AutoLoan & Not utilised \\
\hline Bonds & Bonds \\
\hline CardDebt & Not utilised \\
\hline Cash (Deposits) & DepLoans \\
\hline ComPaper & Bonds \\
\hline Commodities & GoldSDRs \\
\hline ComPropLoan & Not utilised \\
\hline Currency & Cash \\
\hline Equity & Equity \\
\hline FarmLoan & Not utilised \\
\hline FDIDebt & DepLoans \\
\hline FDIEquity & Equity \\
\hline HomeLoan & DepLoans \\
\hline LifePenRes & Equity \\
\hline Loans & $\begin{array}{l}\text { For Households: Not utilised } \\
\text { All other agents: DepLoans }\end{array}$ \\
\hline MultiFamLoan & DepLoans \\
\hline NMTreasuries & Bonds \\
\hline
\end{tabular}




\begin{tabular}{|c|c|}
\hline $\begin{array}{c}\text { FRSR0615 } \\
\text { Instruments }\end{array}$ & USAGE2F Instrument \\
\hline OvrNghtLoan & DepLoans \\
\hline Receivables & Equity \\
\hline Repurps & DepLoans \\
\hline Reserves & DepLoans \\
\hline ResidentRE & $\begin{array}{c}\text { Netted against HomeLoan and } \\
\text { MultiFamLoan, then allocated to } \\
\text { Equity }\end{array}$ \\
\hline RevRepurps & $\begin{array}{c}\text { DepLoans } \\
\text { GoldSDRs }\end{array}$ \\
\hline SDR & $\begin{array}{c}\text { From Government: DepLoans } \\
\text { All others: Not utilised }\end{array}$ \\
\hline StudentLoan & Bonds \\
\hline TBills & Bonds \\
\hline Treasuries & Bonds \\
\hline USSavingsBnd & \\
\hline
\end{tabular}

Table 8: Selected USAGE2F Financial Database shares compared to their Australian Financial Database counterparts

\begin{tabular}{|c|c|c|c|c|c|c|c|c|c|c|c|}
\hline $\begin{array}{l}\text { USAGE2F Financial Database Shares vs } \\
\text { Australian Financial Database Shares } \\
\text { Initial ownership share by instrument } \\
\text { and counterparty }\end{array}$ & Bank & CB & Fgn & Govt. & Hlds & Inds & NBFI & Ret. & $\begin{array}{l}\text { Life } \\
\text { Ins }\end{array}$ & NRH & RH \\
\hline \multicolumn{12}{|l|}{ Reproducible Housing Loans } \\
\hline USAGE2F & 28.7 & 0.0 & 0.0 & 2.1 & 0.6 & 0.4 & 67.7 & 0.1 & 0.5 & 0.0 & 0.0 \\
\hline Australian FCGE model & 75.8 & 0.0 & 2.3 & 2.5 & 0.0 & 0.3 & 18.2 & 0.8 & 0.0 & 0.0 & 0.0 \\
\hline Difference & 47.1 & 0.0 & 2.3 & 0.5 & 0.6 & 0.1 & 49.5 & 0.7 & 0.5 & 0.0 & 0.0 \\
\hline \multicolumn{12}{|l|}{ Industry Loans } \\
\hline USAGE2F & 50.7 & 0.0 & 17.0 & 4.0 & 0.6 & 0.0 & 27.1 & 0.0 & 0.7 & 0.0 & 0.0 \\
\hline Australian FCGE model & 65.5 & 0.0 & 16.6 & 8.5 & 3.1 & 0.0 & 5.9 & 0.0 & 0.5 & 0.0 & 0.0 \\
\hline Difference & 14.8 & 0.0 & 0.4 & 4.5 & 2.5 & 0.0 & 21.2 & 0.0 & 0.2 & 0.0 & 0.0 \\
\hline \multicolumn{12}{|l|}{ Industry Equity } \\
\hline USAGE2F & 0.2 & 0.0 & 18.9 & 1.4 & 50.9 & 0.0 & 13.9 & 10.8 & 4.0 & 0.0 & 0.0 \\
\hline Australian FCGE model & 1.1 & 0.0 & 37.9 & 1.3 & 32.0 & 0.0 & 10.0 & 16.8 & 0.9 & 0.0 & 0.0 \\
\hline Difference & 1.0 & 0.0 & 19.1 & 0.2 & 18.9 & 0.0 & 3.9 & 6.0 & 3.1 & 0.0 & 0.0 \\
\hline \multicolumn{12}{|l|}{ NBFI Equity } \\
\hline USAGE2F & 0.7 & 0.1 & 9.5 & 1.8 & 54.1 & 7.4 & 0.0 & 23.2 & 3.3 & 0.0 & 0.0 \\
\hline Australian FCGE model & 3.3 & 0.0 & 11.9 & 4.8 & 19.1 & 6.1 & 0.0 & 28.9 & 25.8 & 0.0 & 0.0 \\
\hline Difference & 2.6 & 0.1 & 2.5 & 2.9 & 35.0 & 1.3 & 0.0 & 5.7 & 22.6 & 0.0 & 0.0 \\
\hline
\end{tabular}




\section{$7 \quad$ Figures}

Figure 1

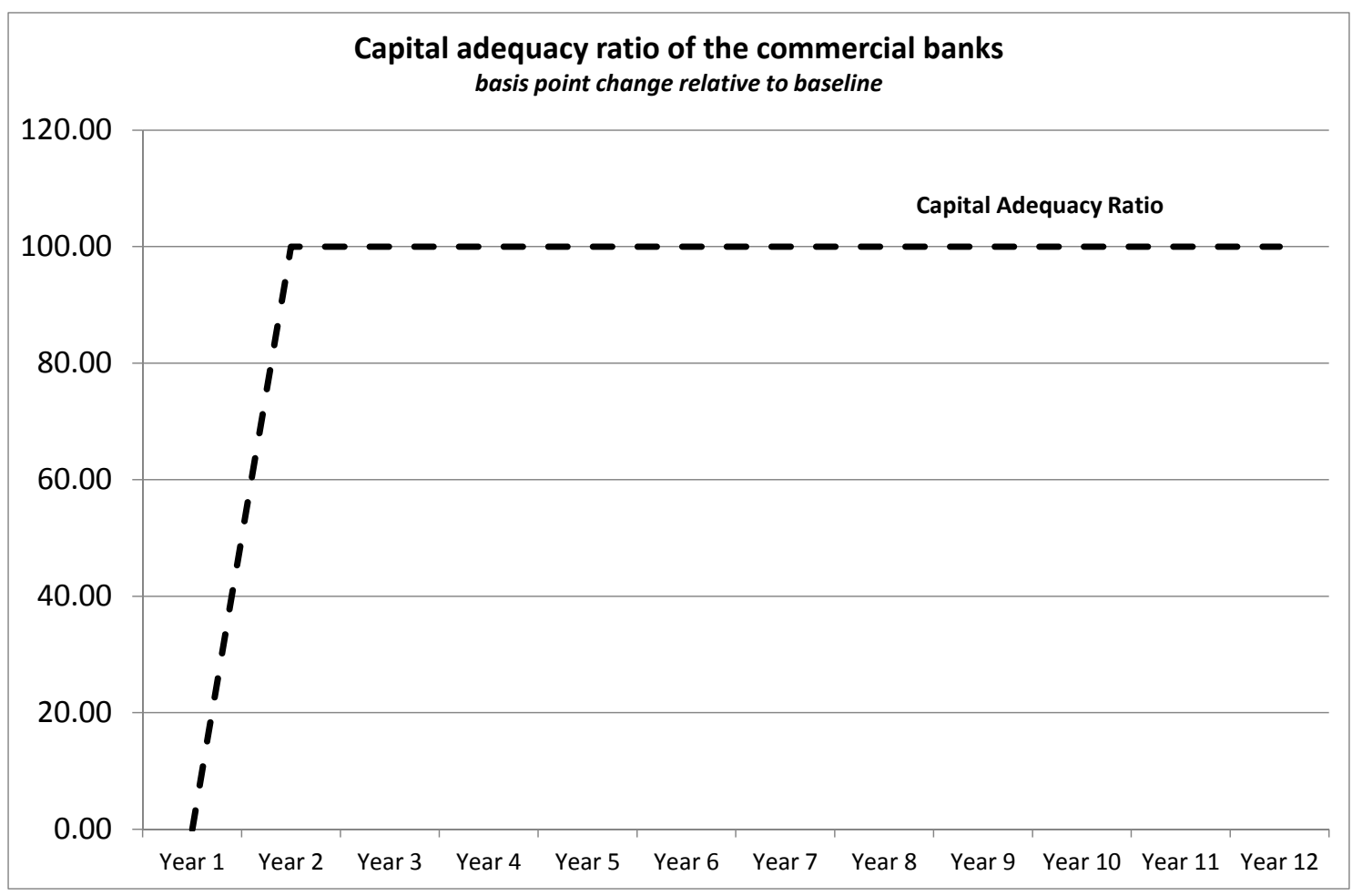

Figure 2

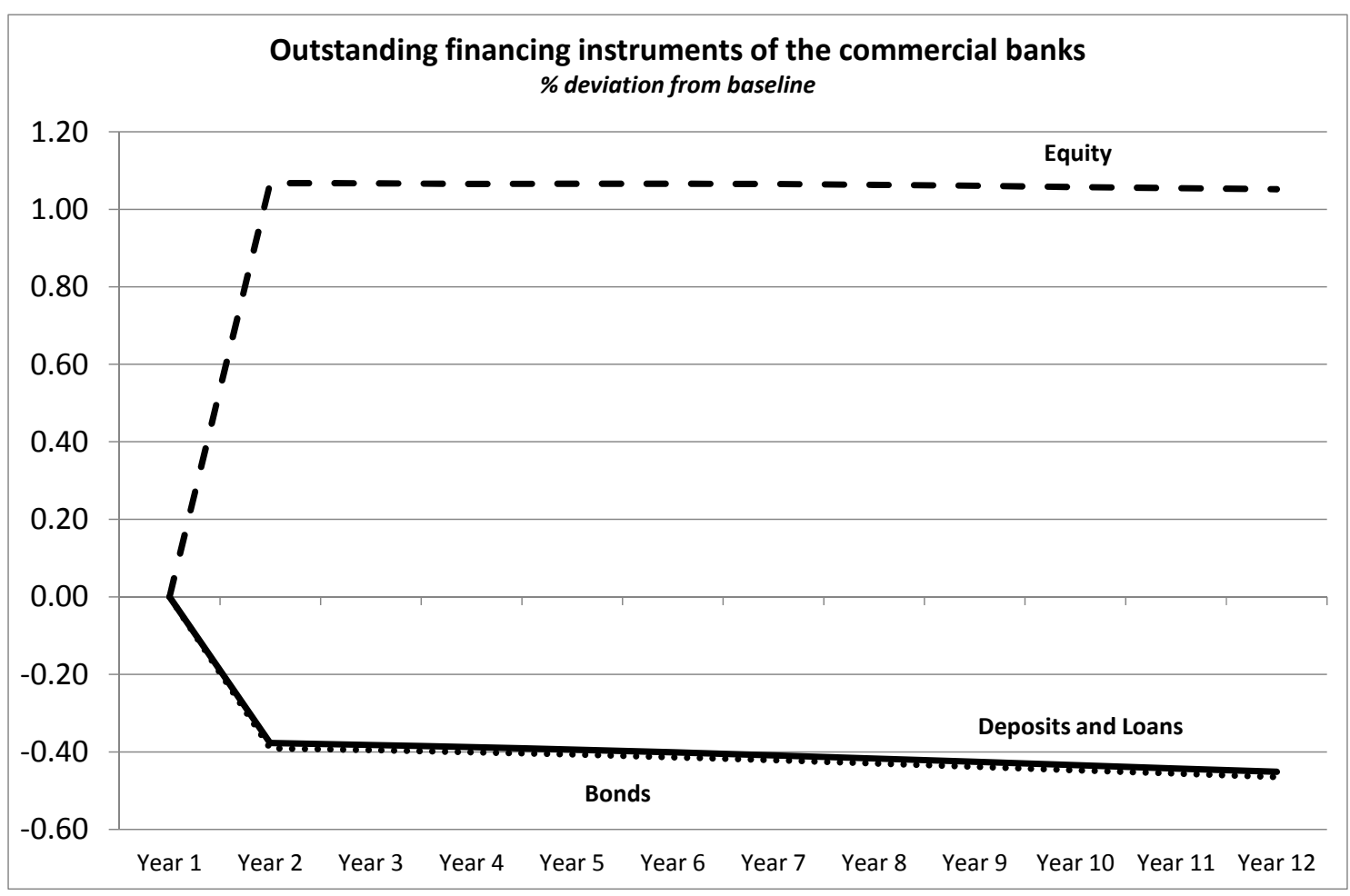


Figure 3

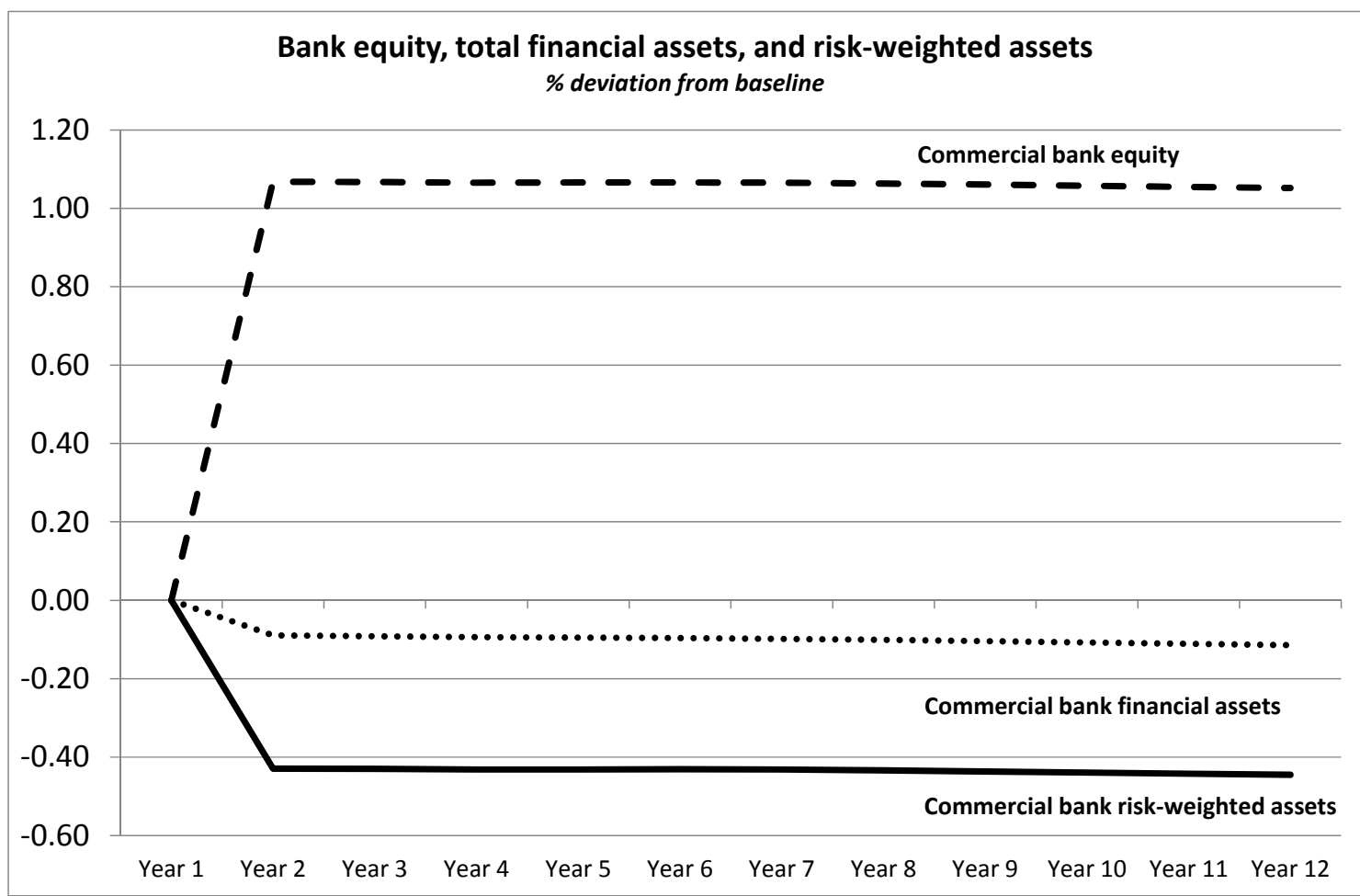

Figure 4

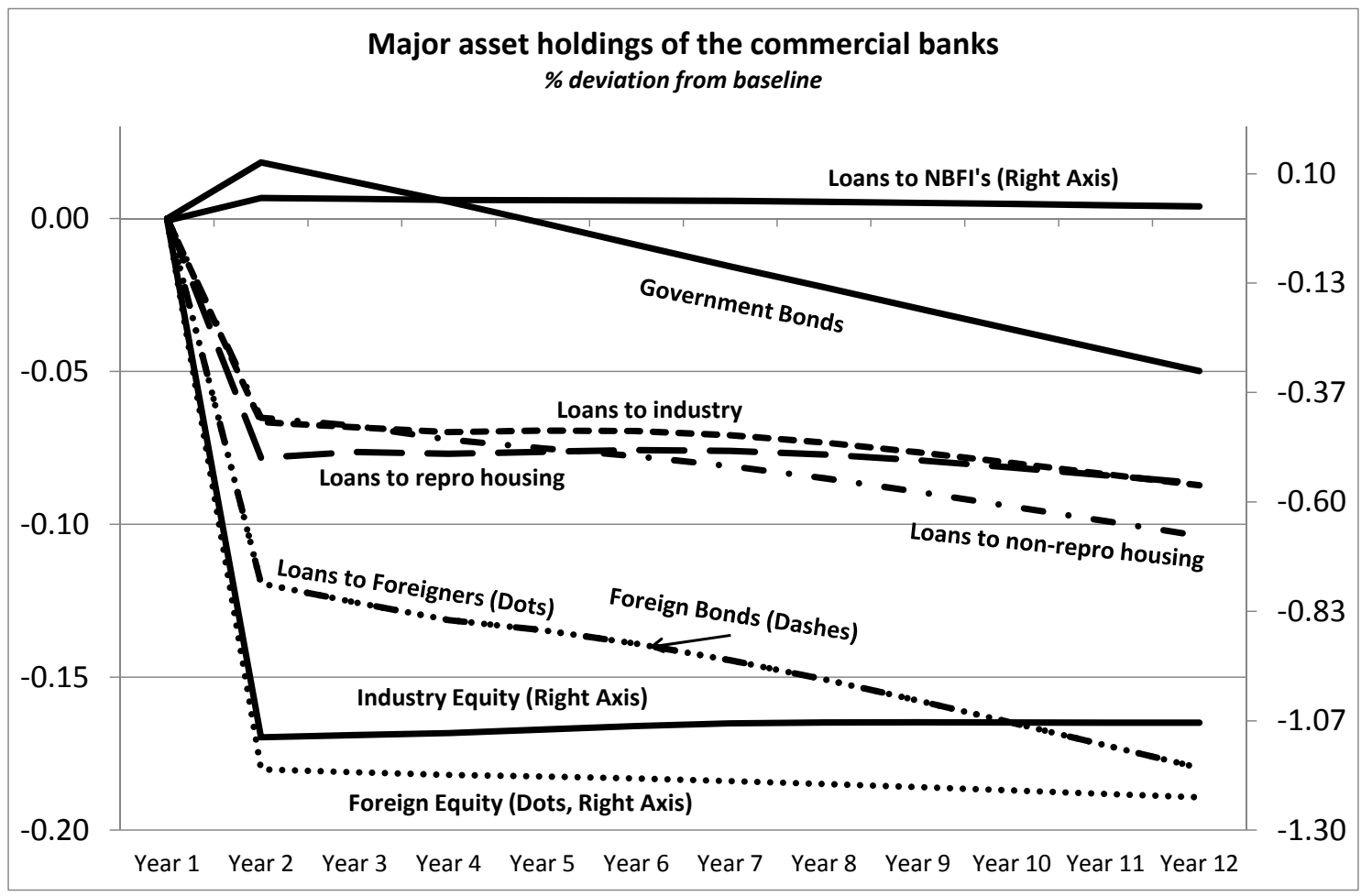


Figure 5

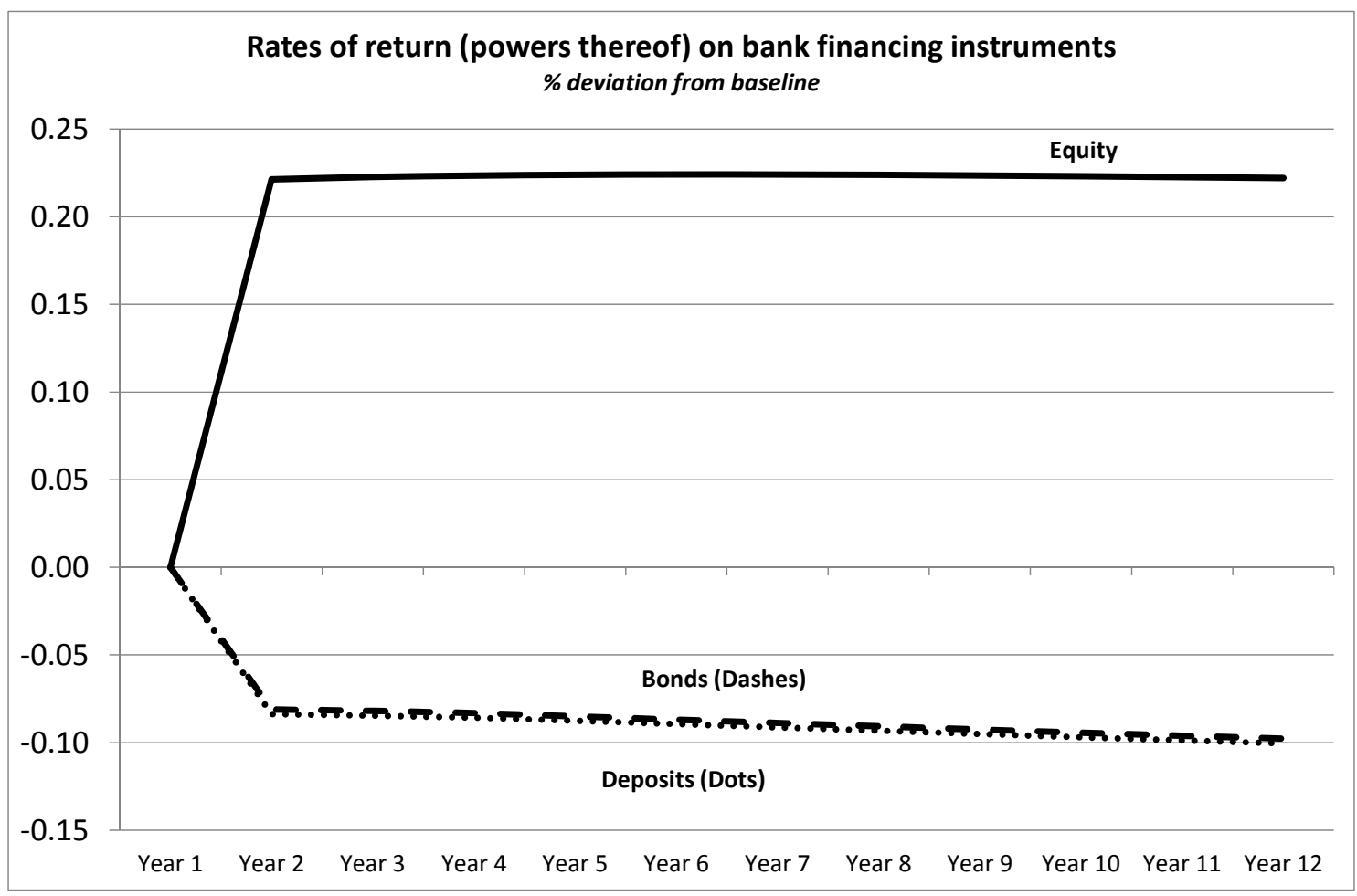

Figure 6

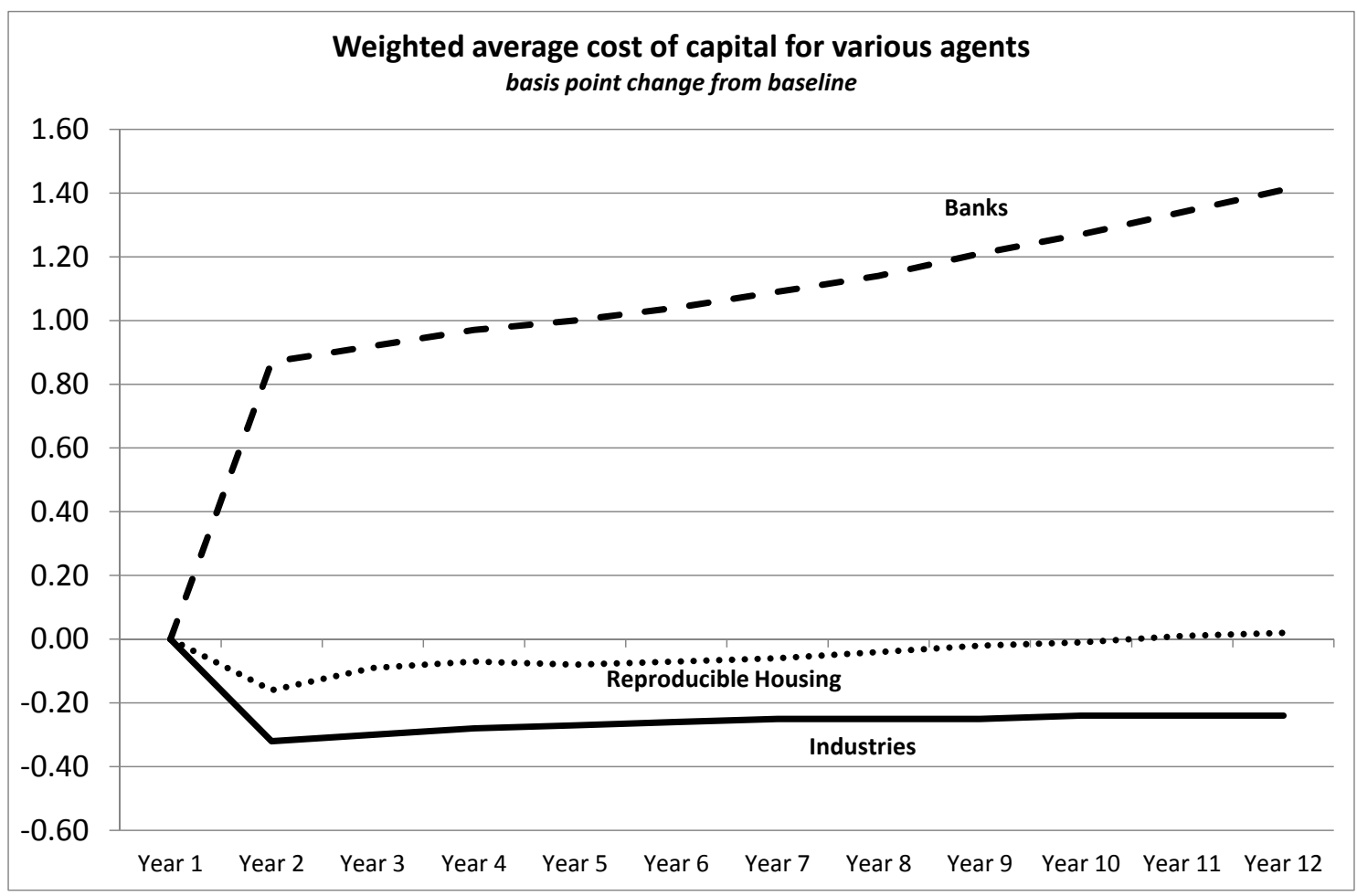


Figure 7

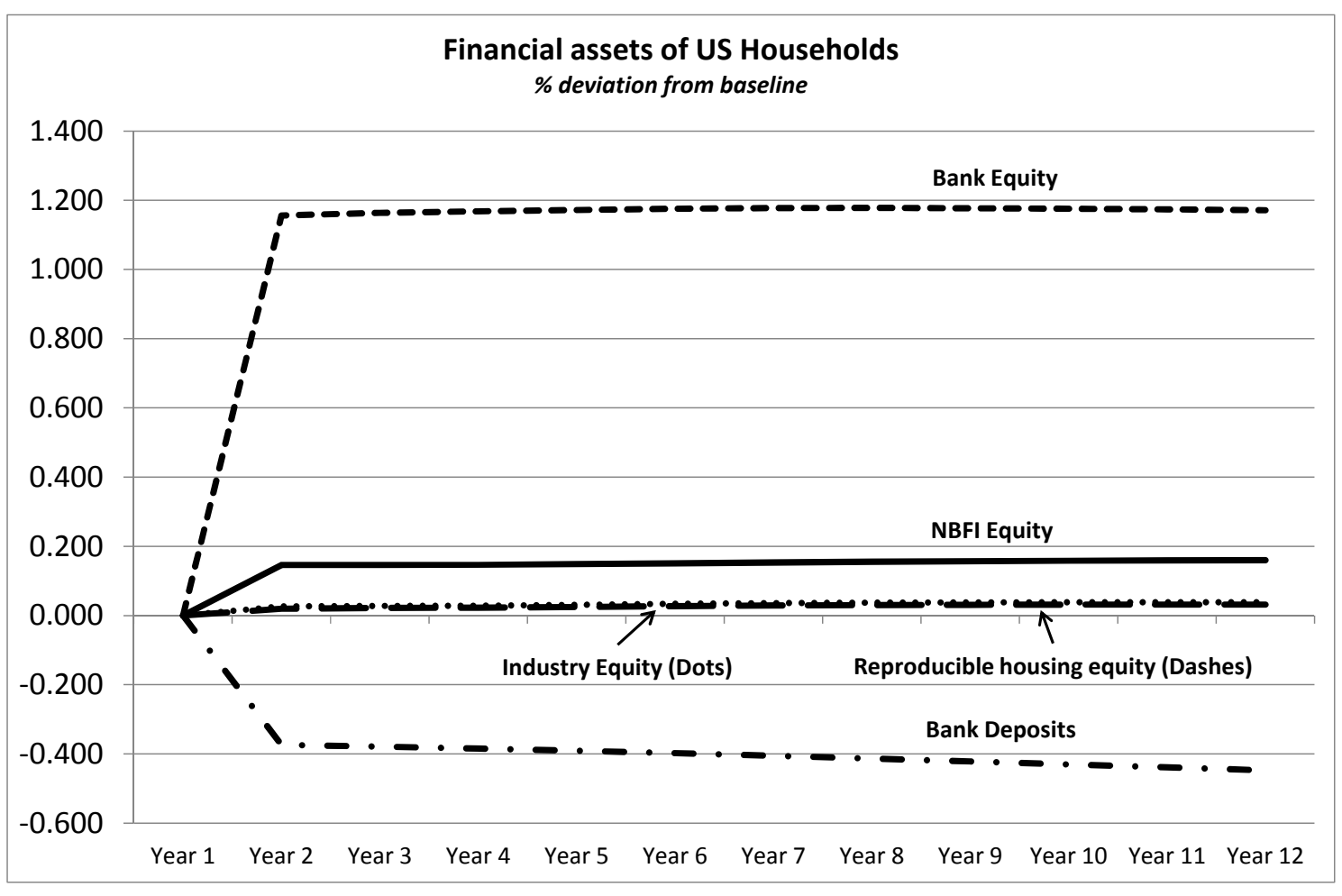


Figure 8

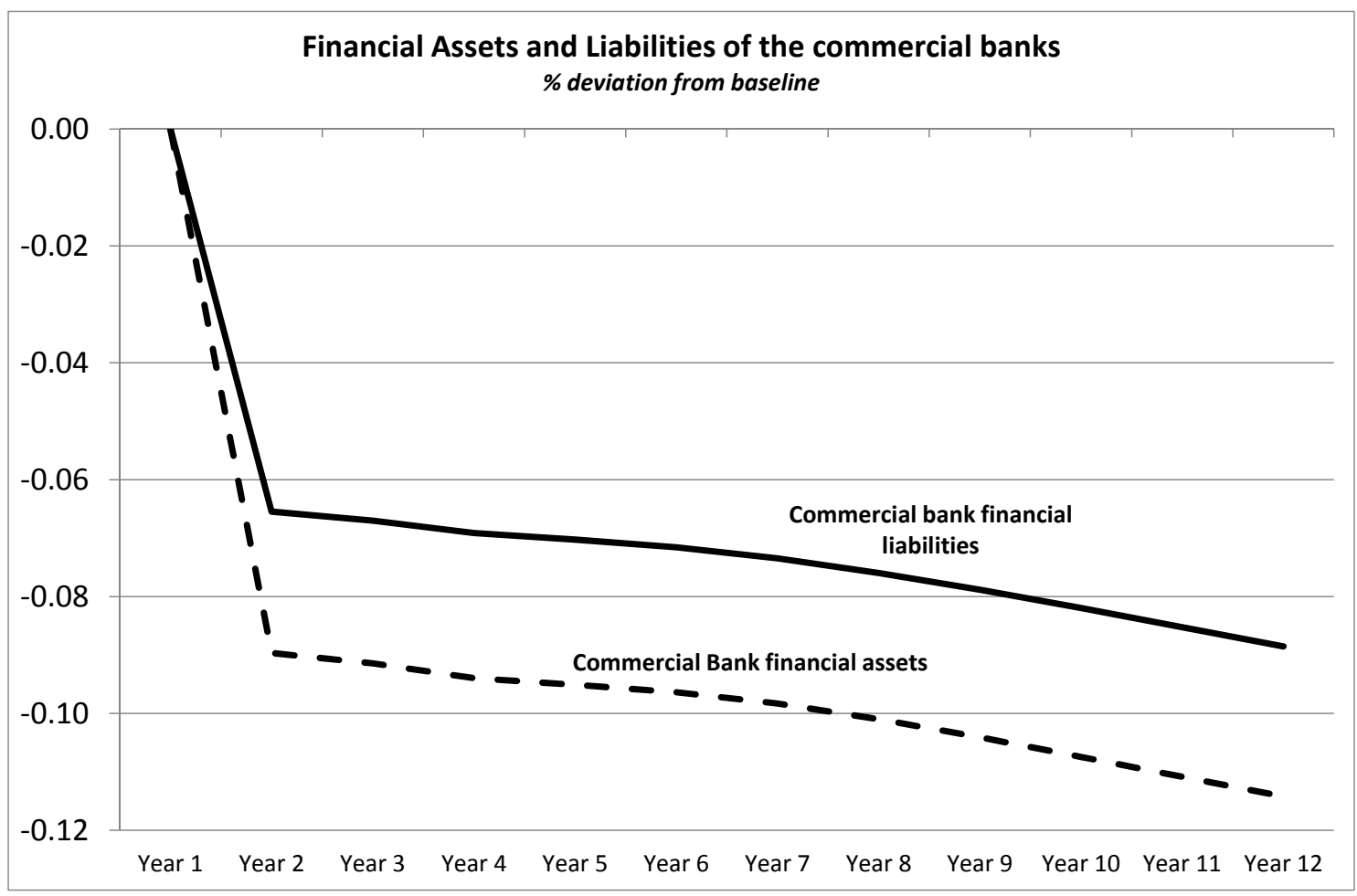

Figure 9

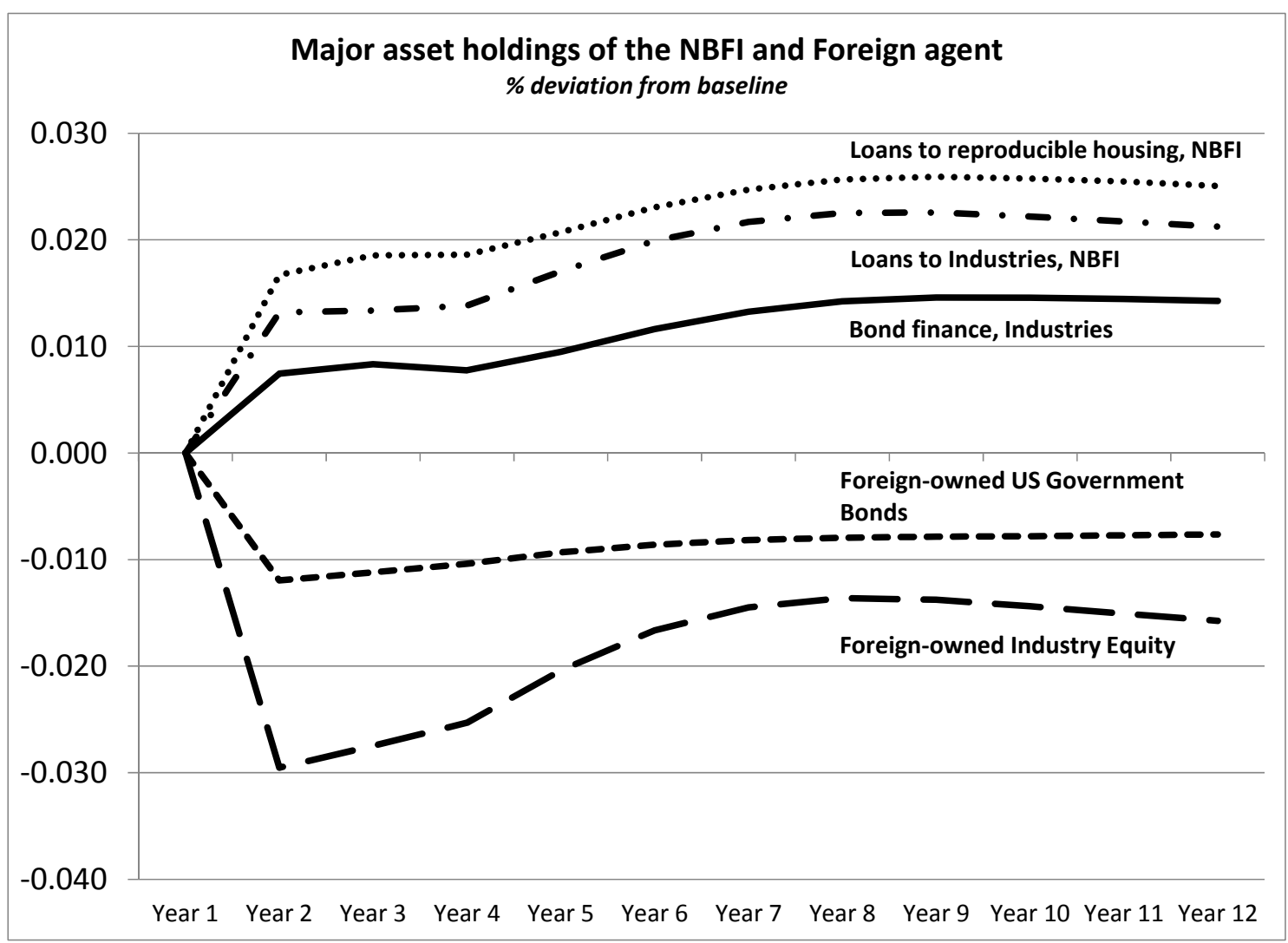


Figure 10

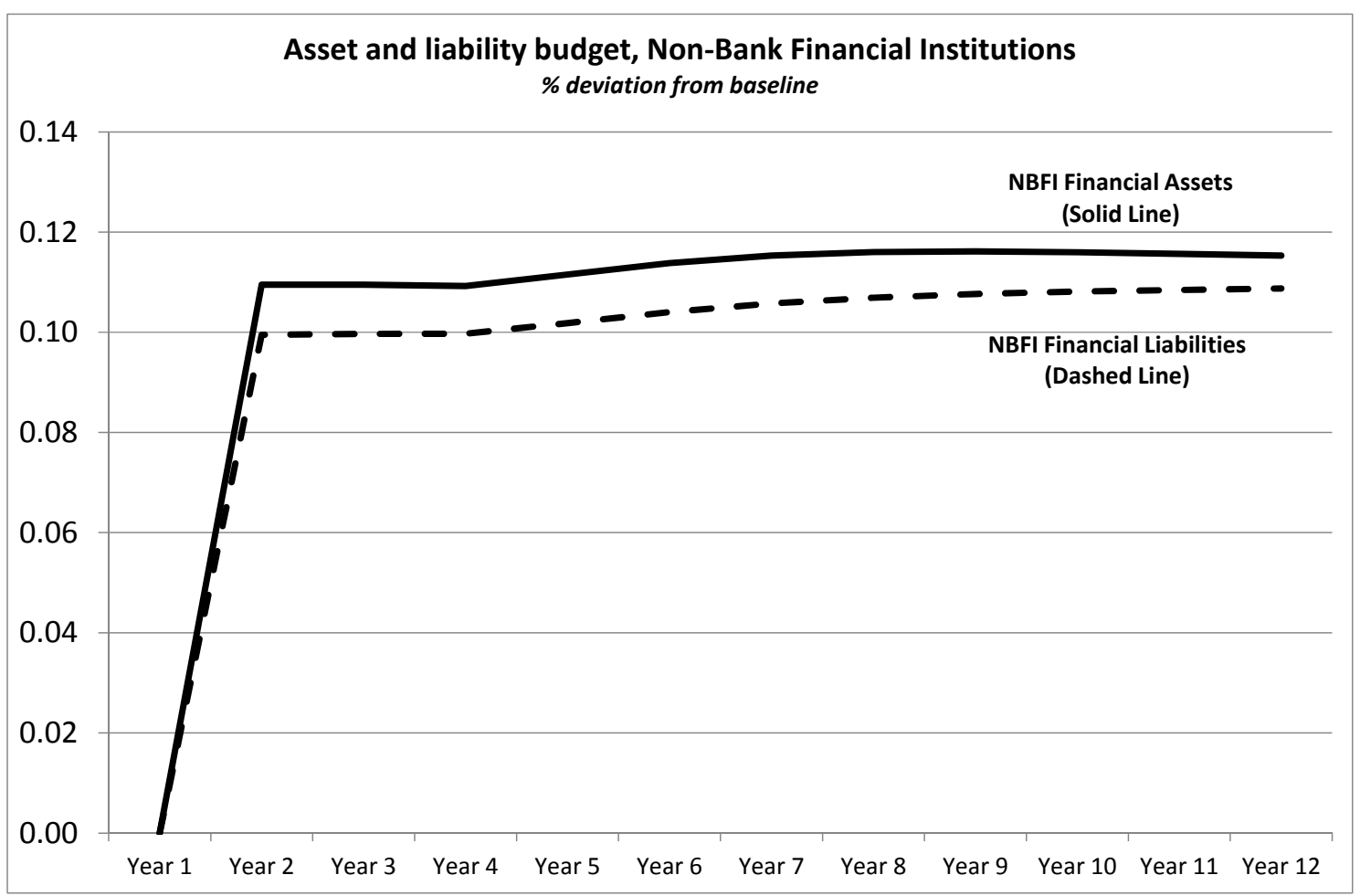


Figure 11

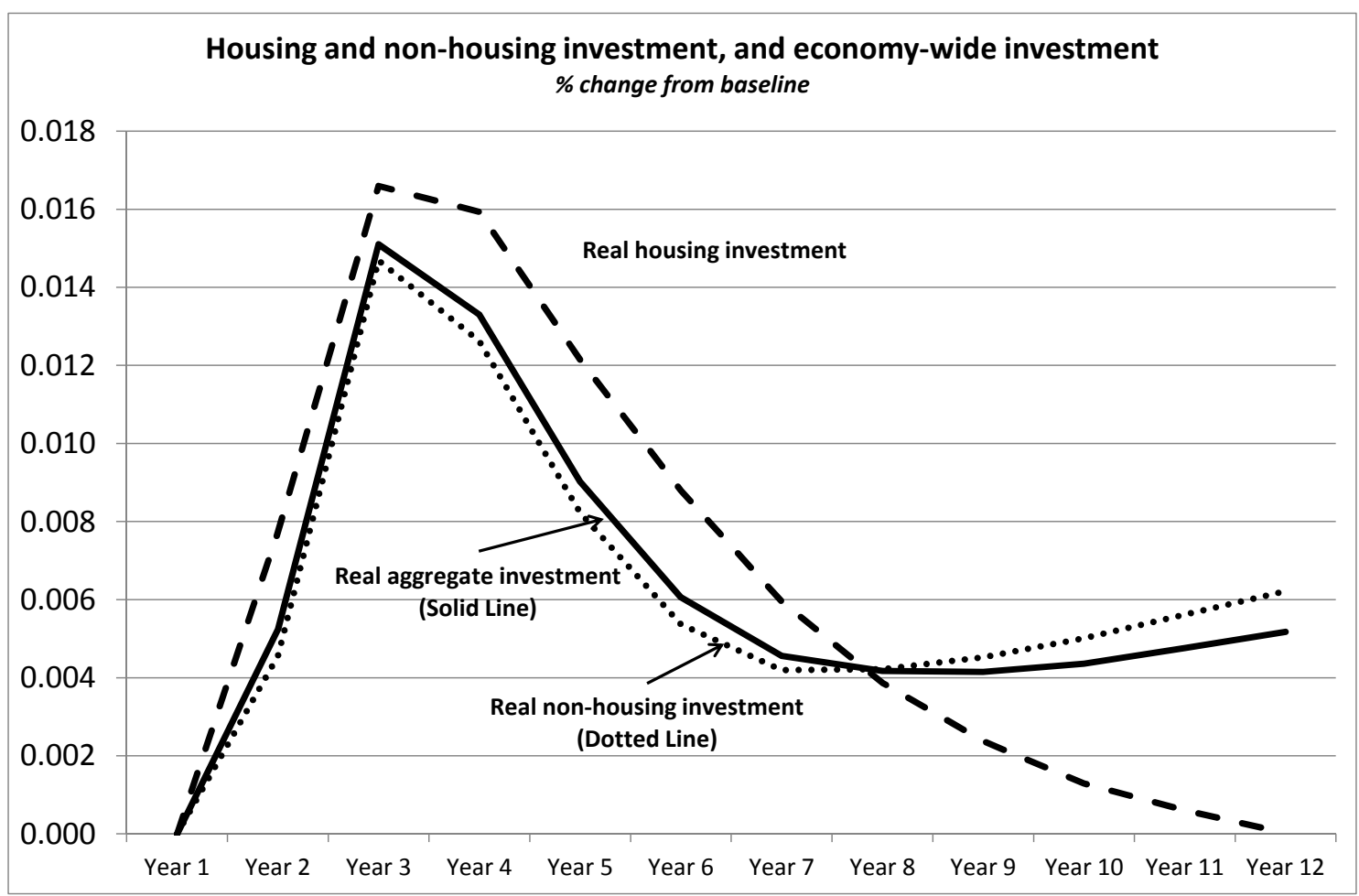


Figure 12

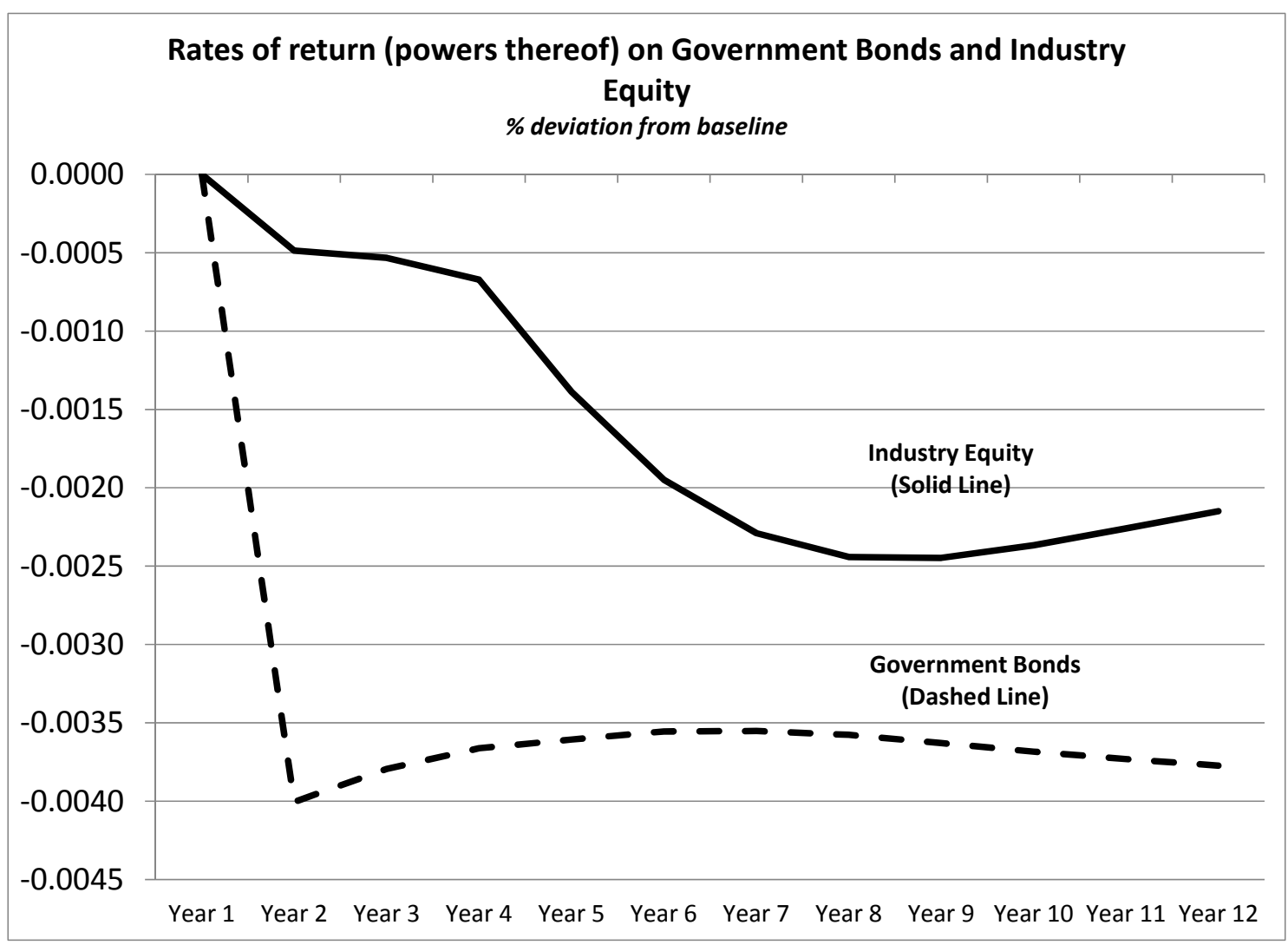


Figure 13

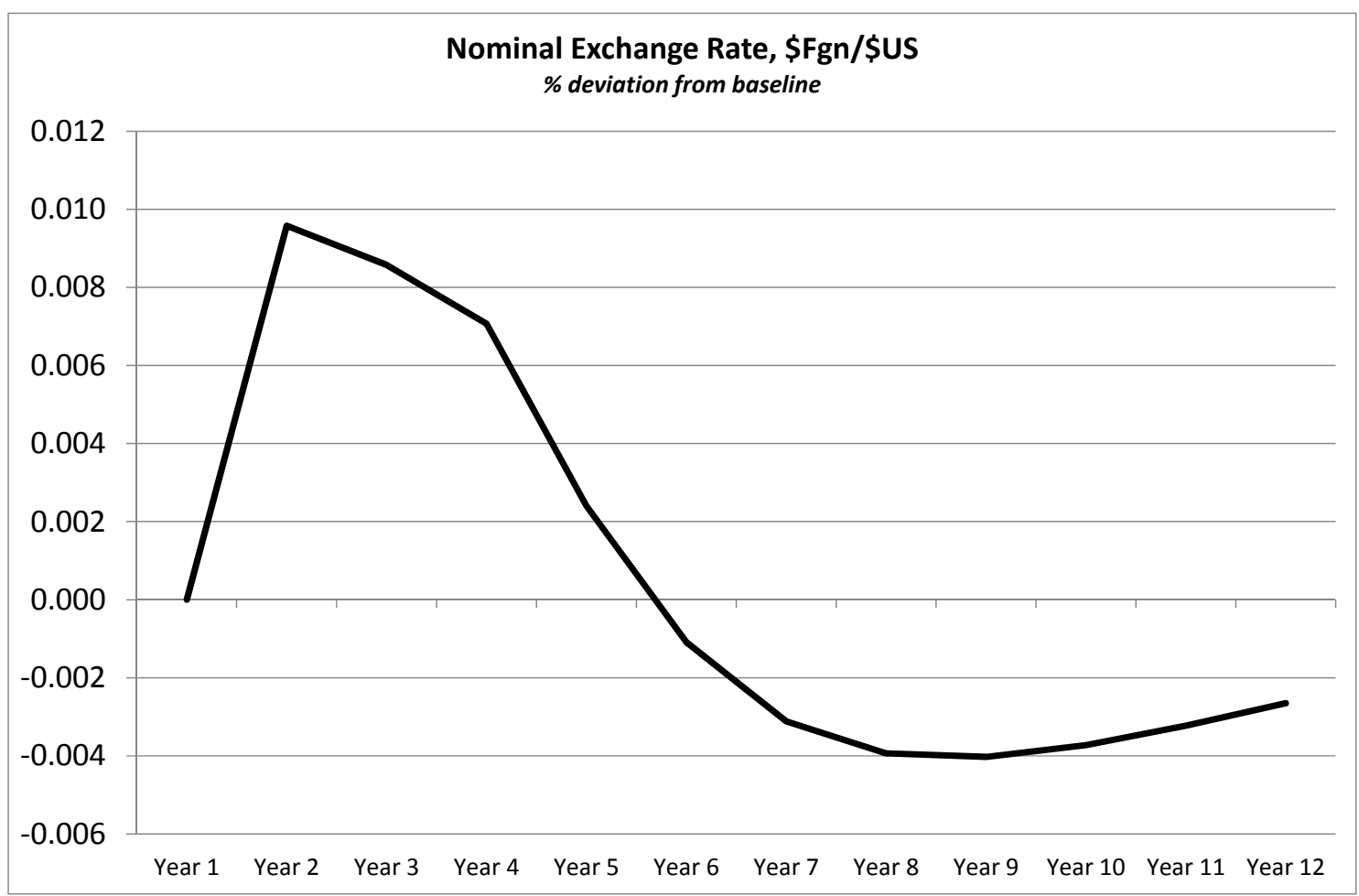

Figure 14

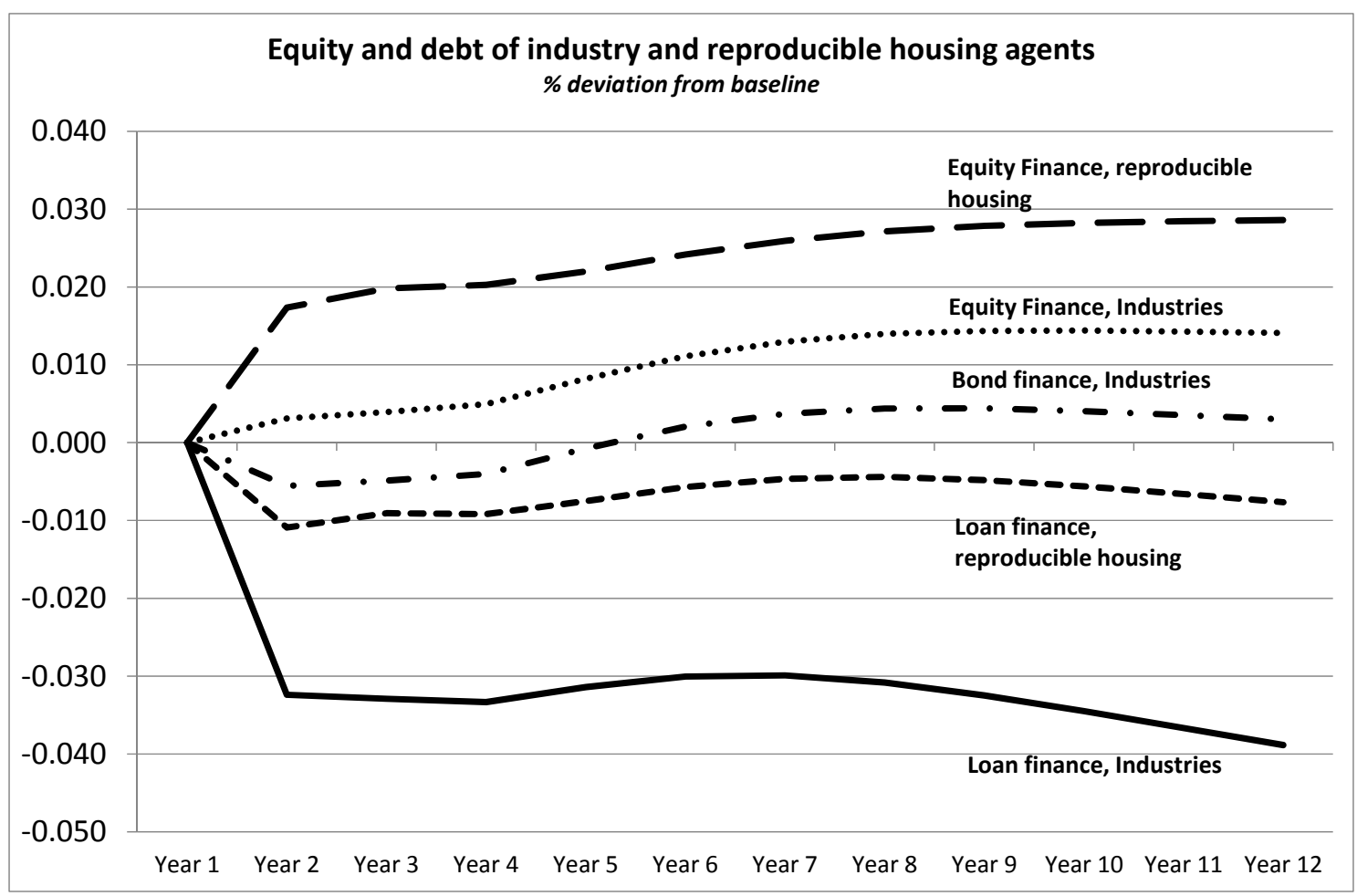


Figure 15

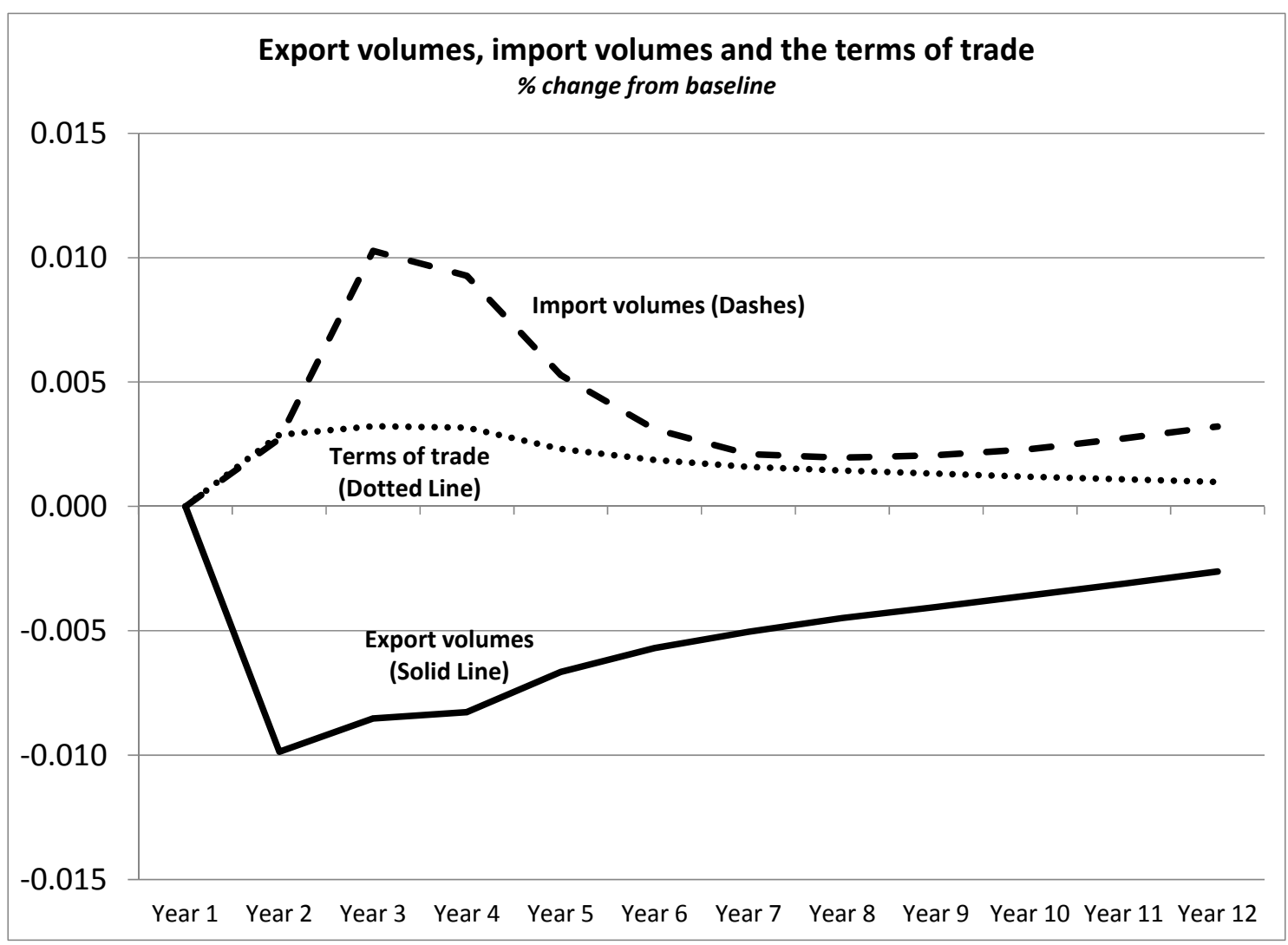


Figure 16

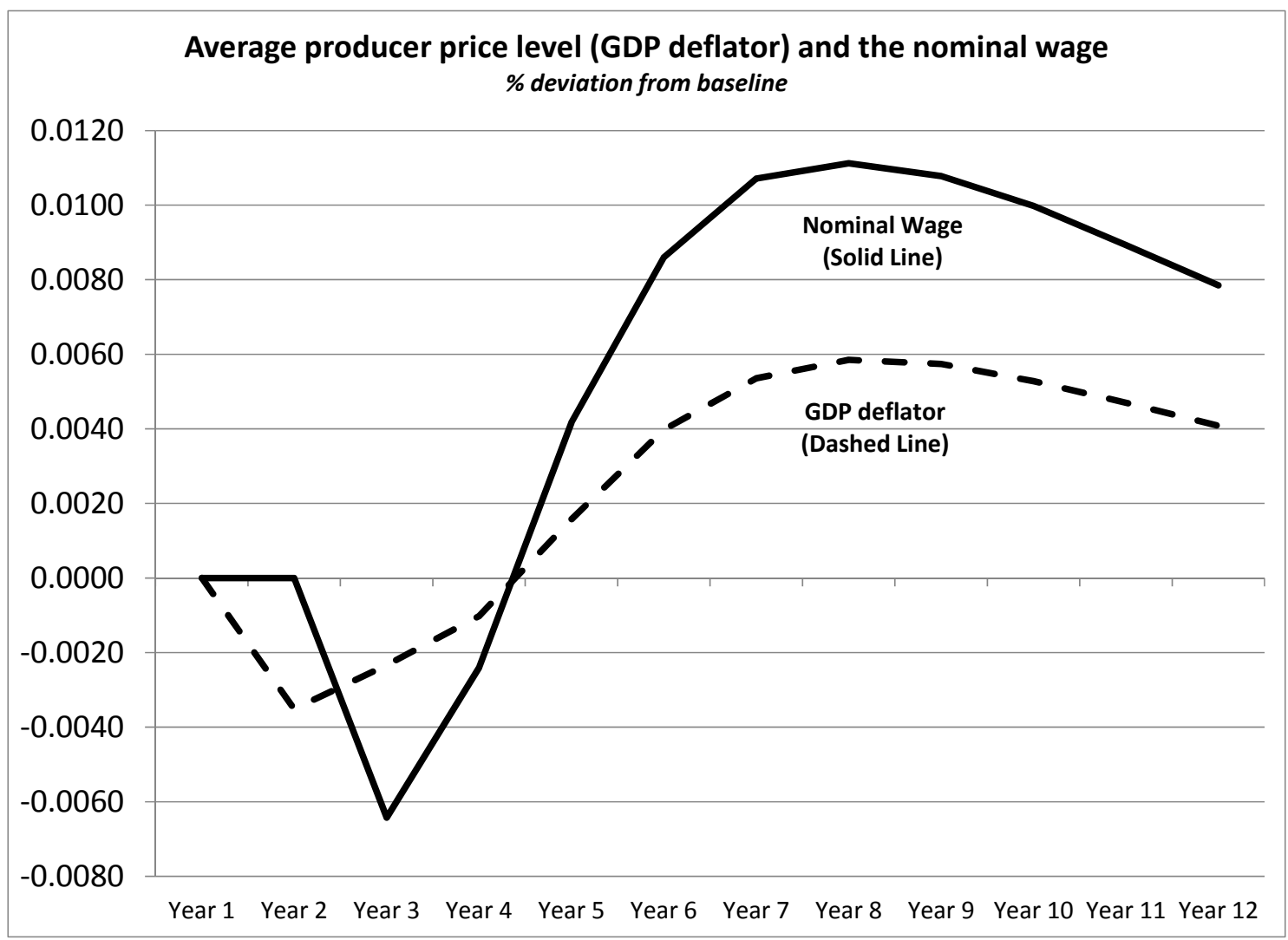


Figure 17

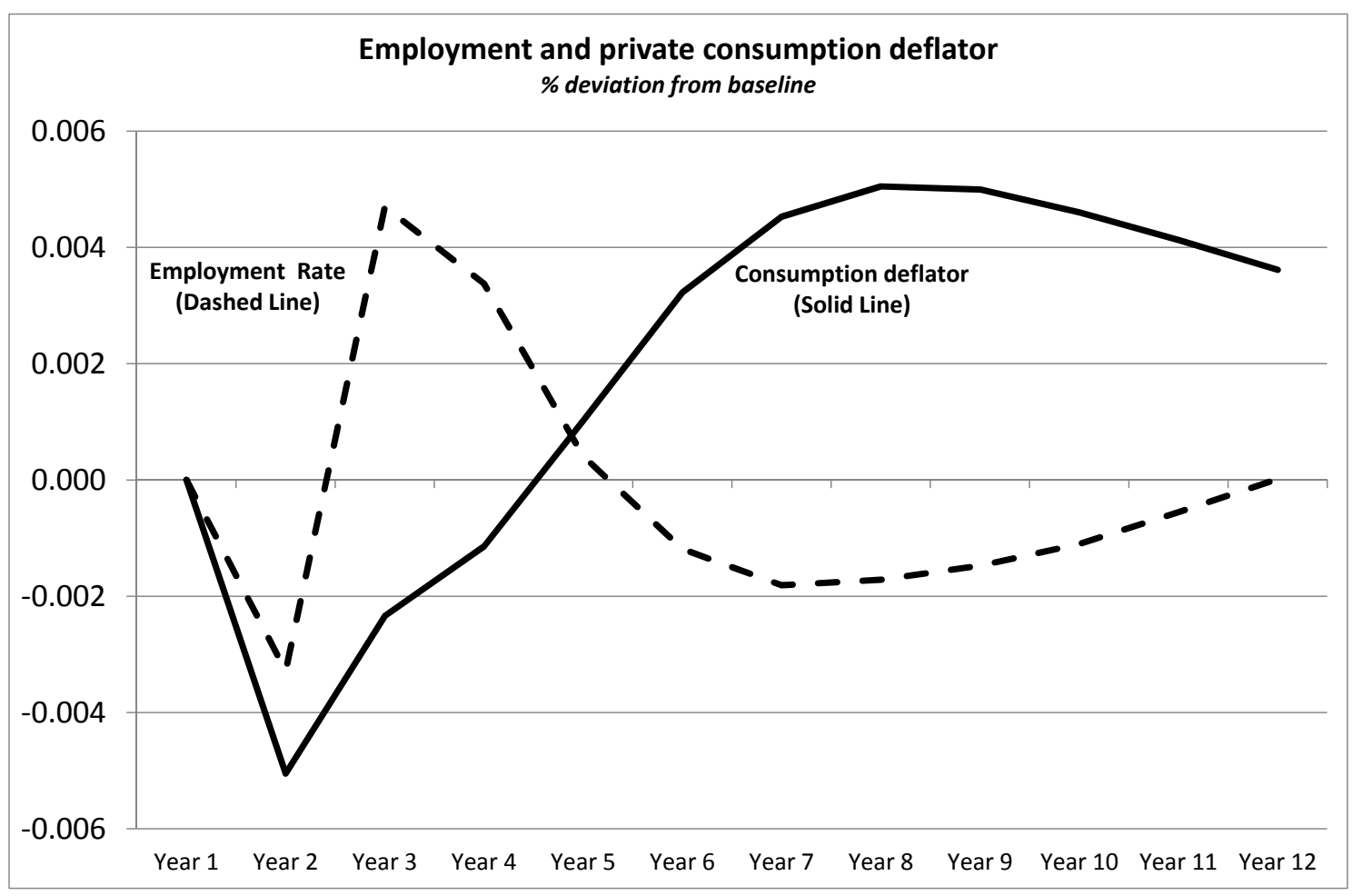

Figure 18

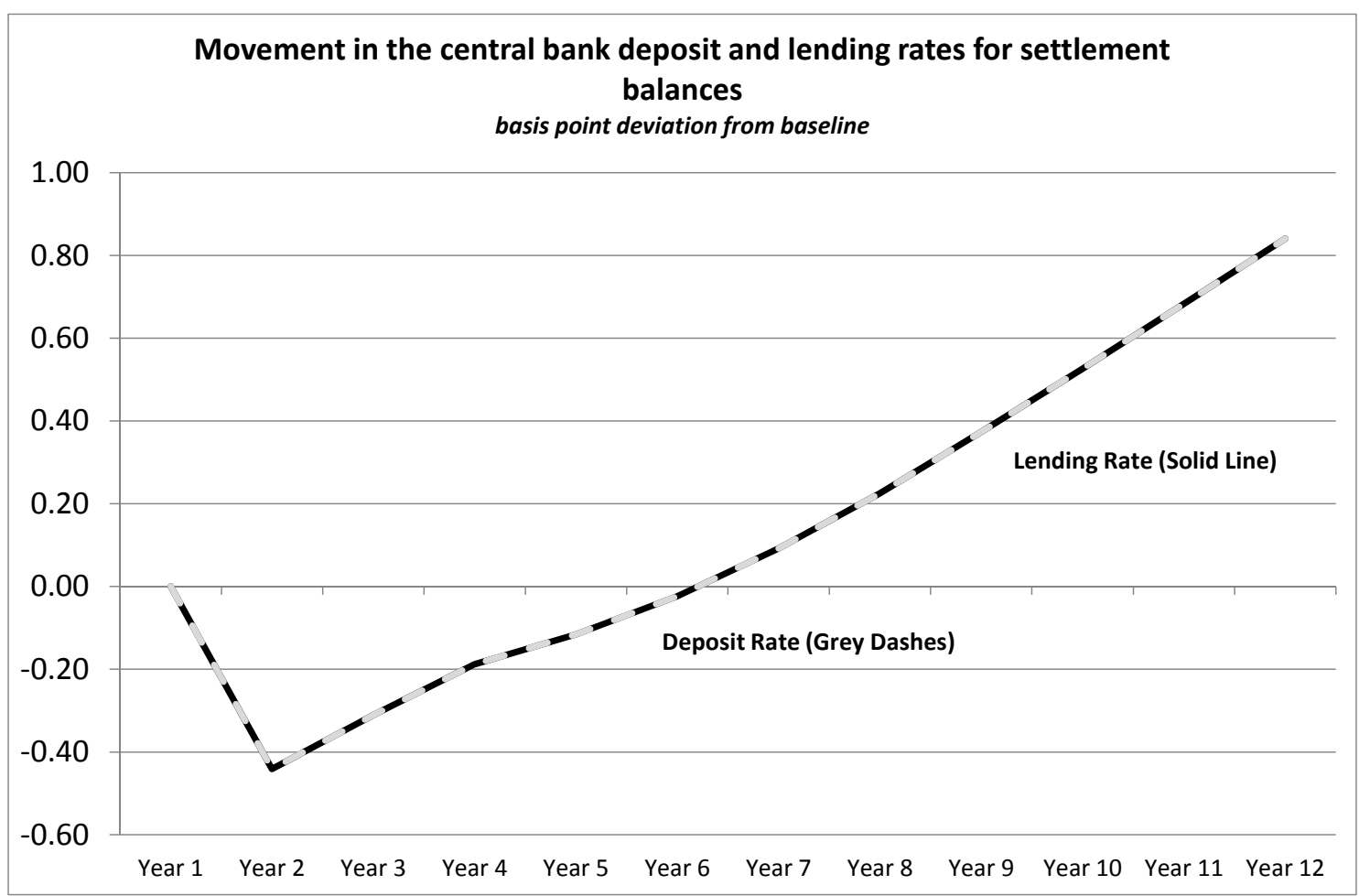


Figure 19

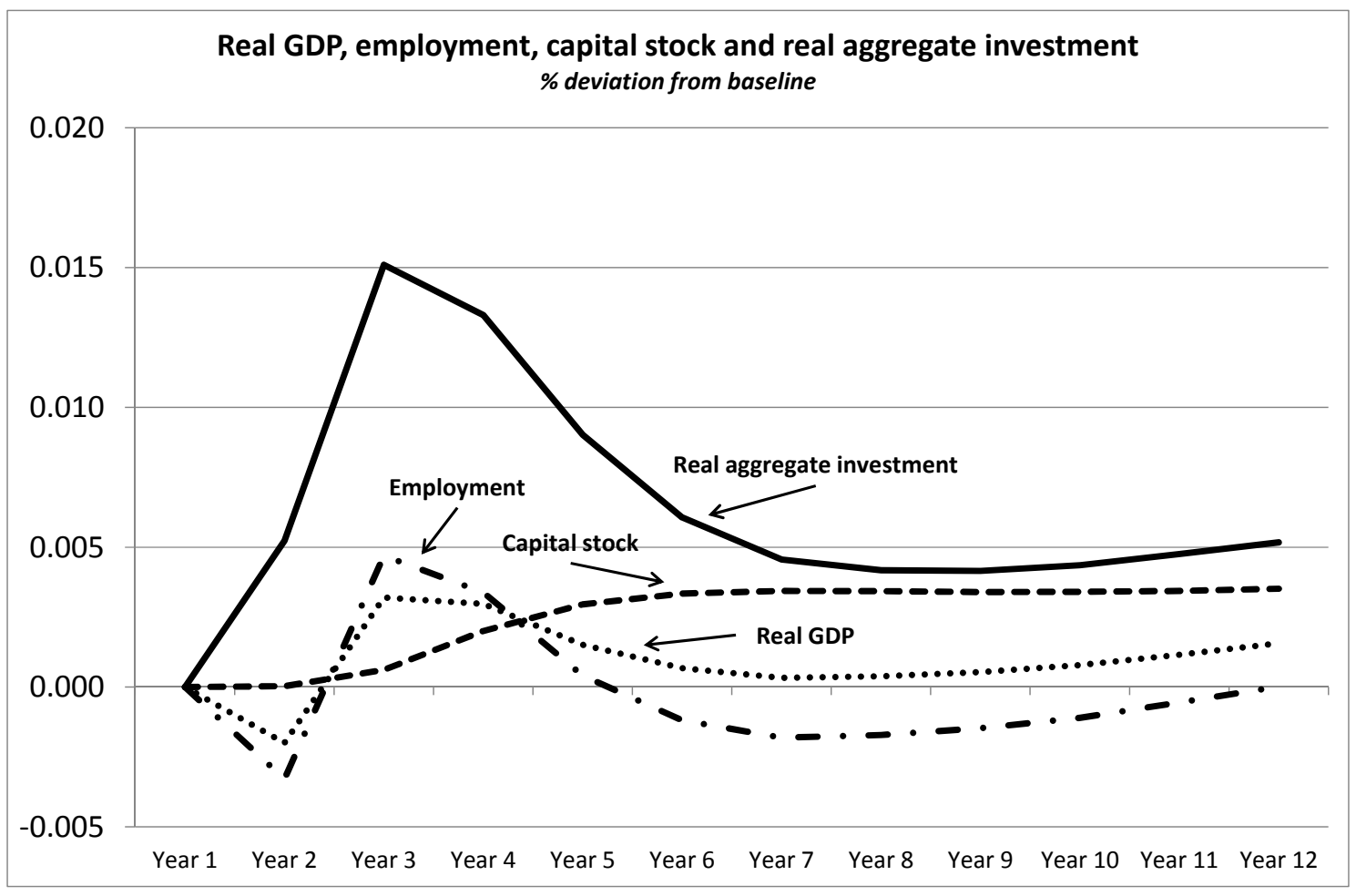

Figure 20

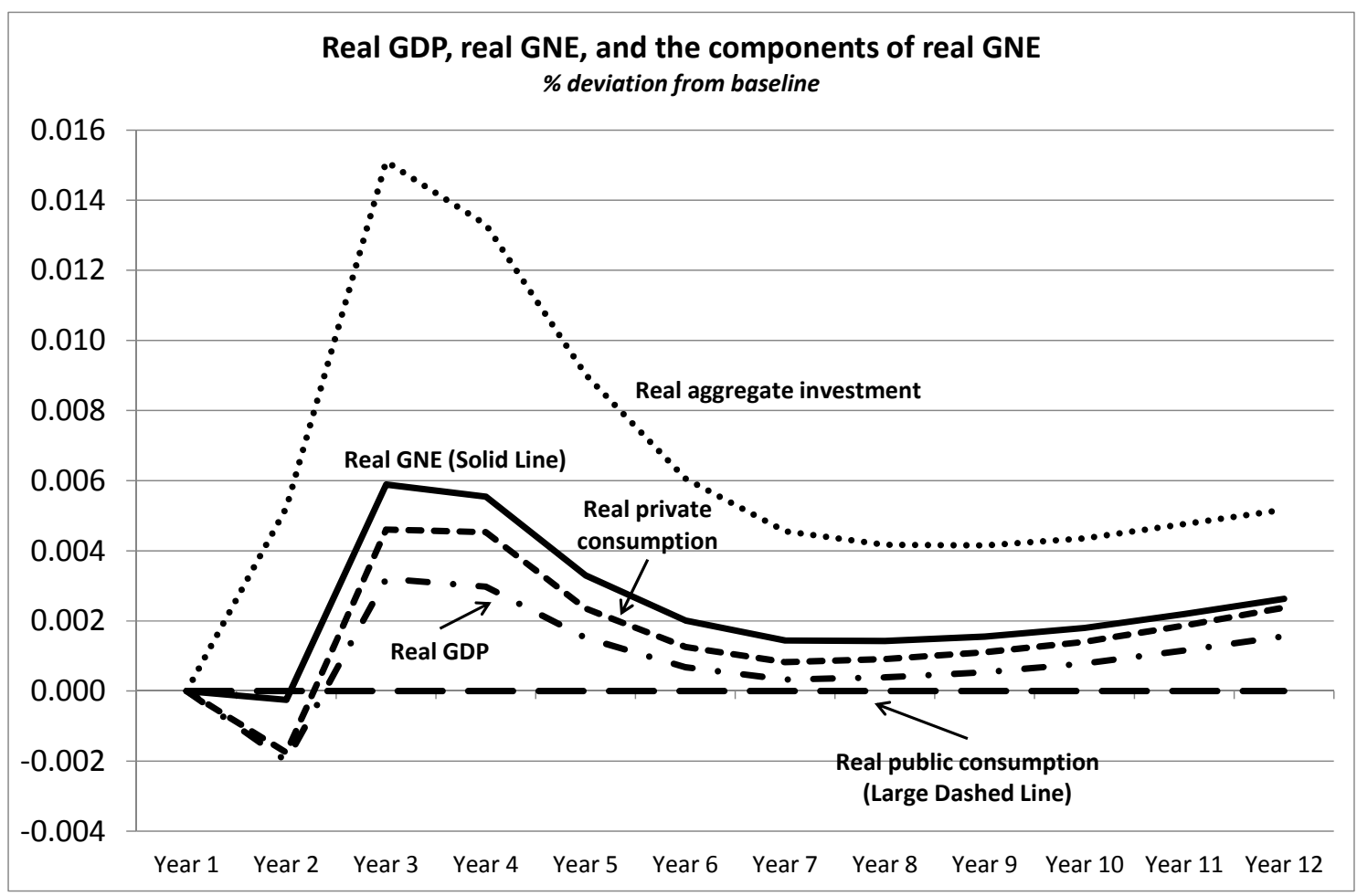


Figure 21

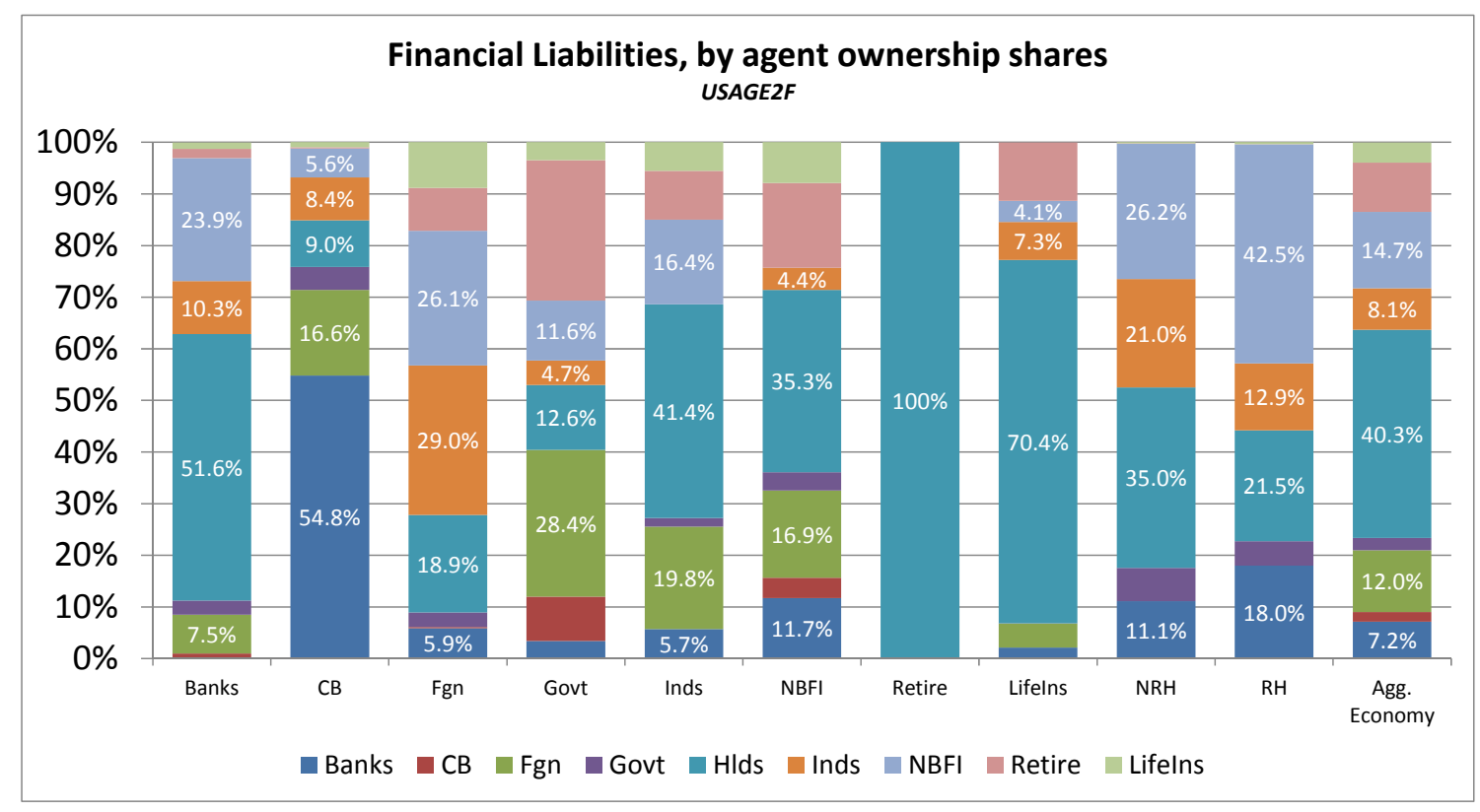

Figure 22

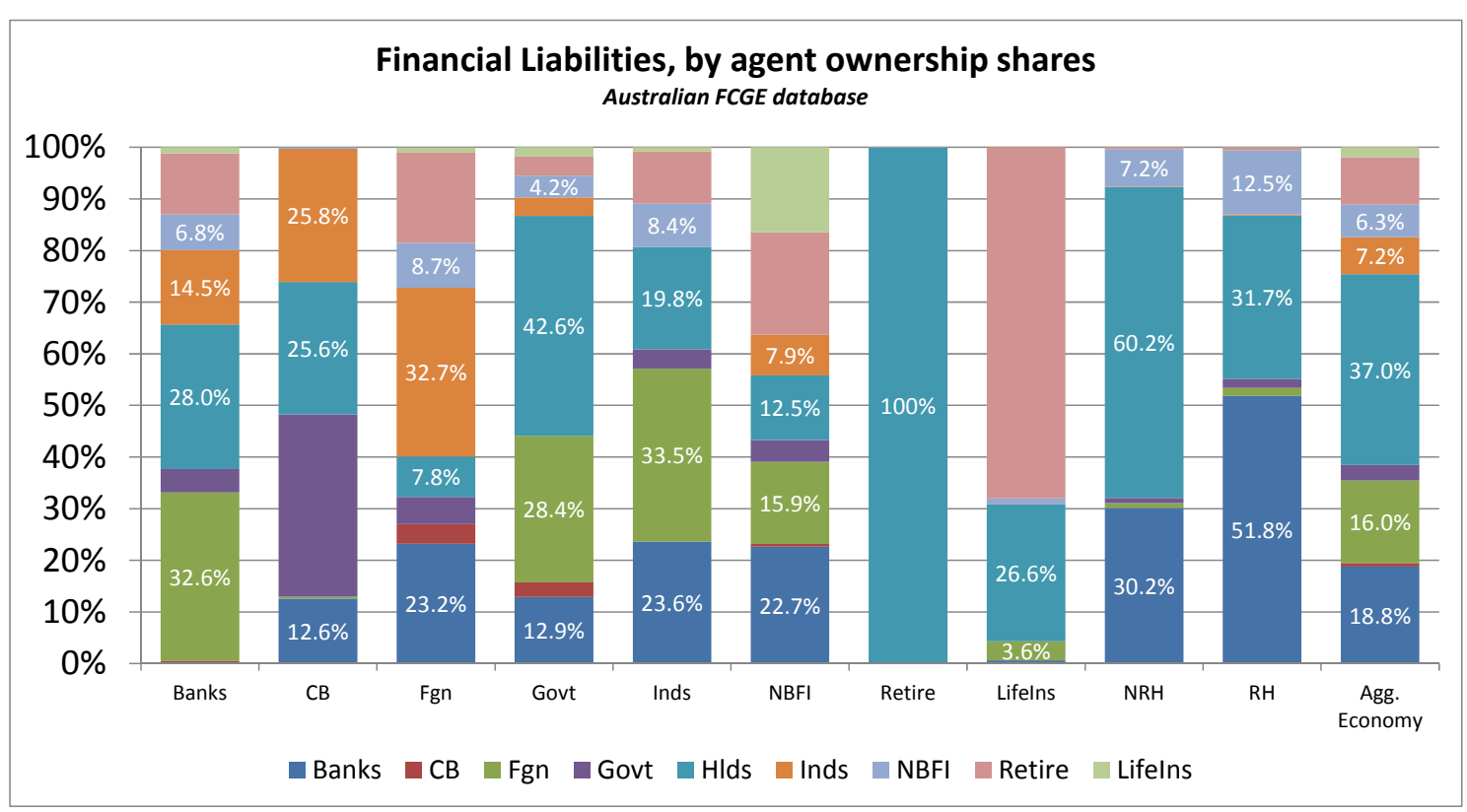


Figure 23

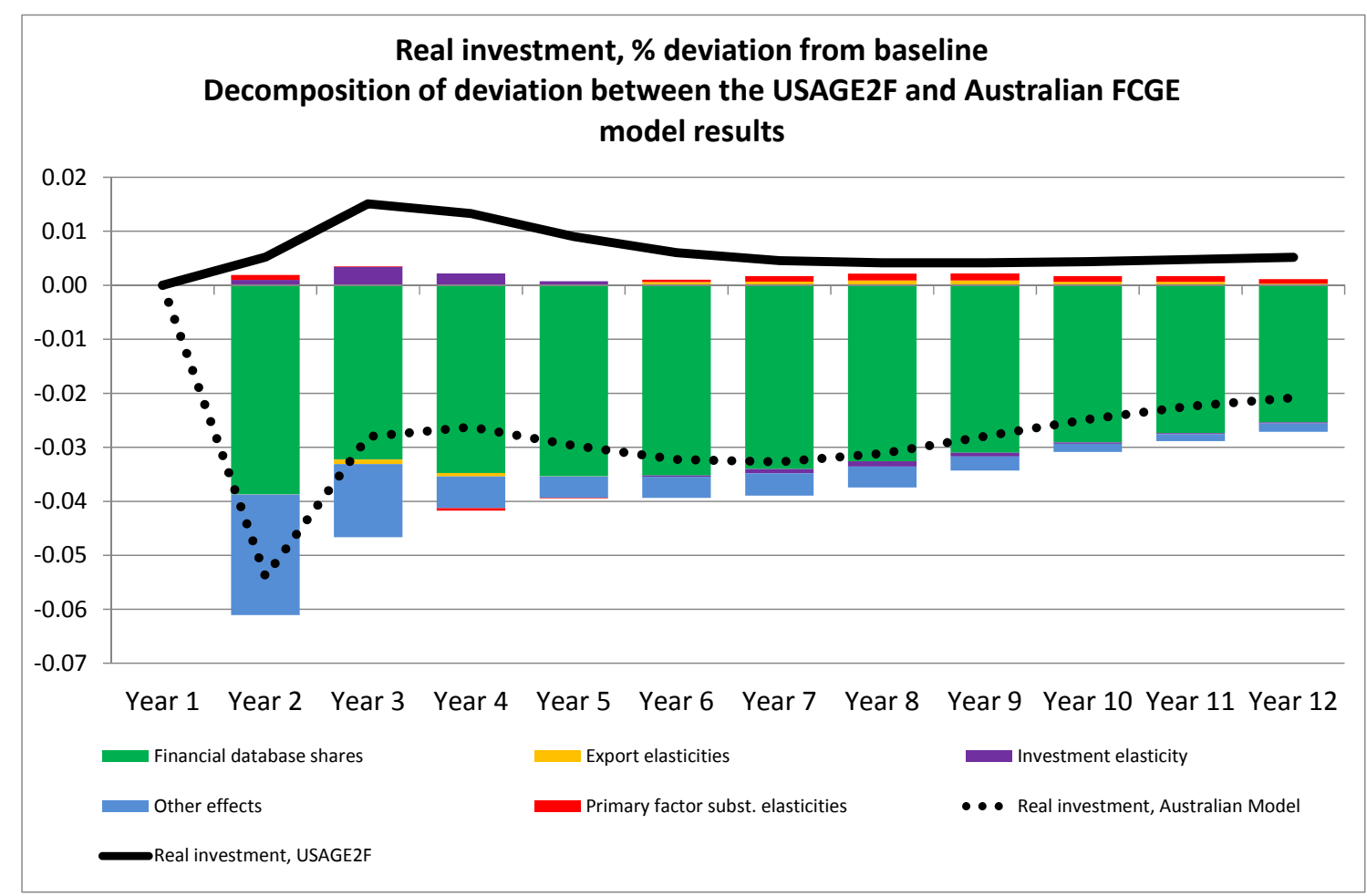

Figure 24

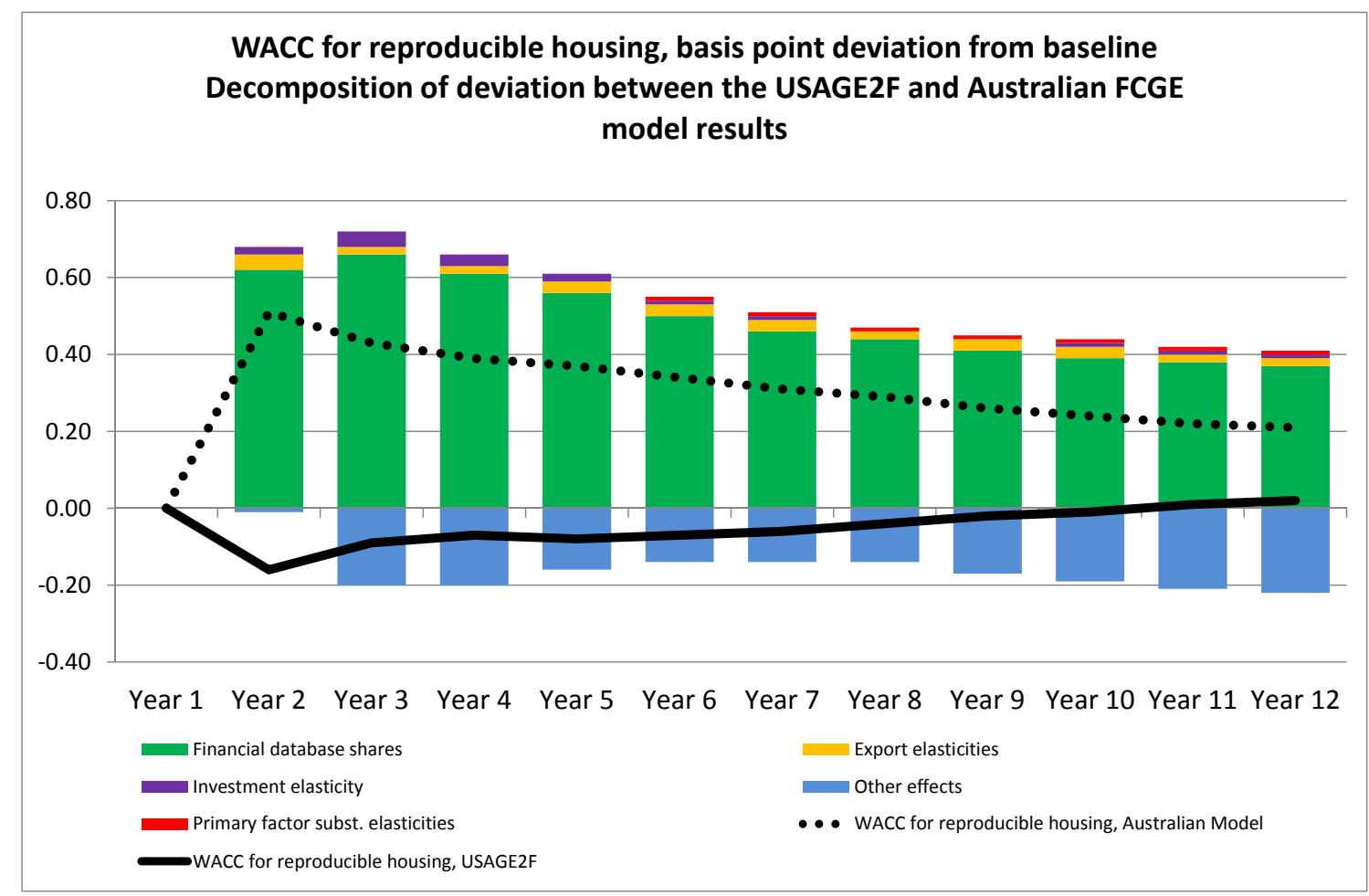


Figure 25

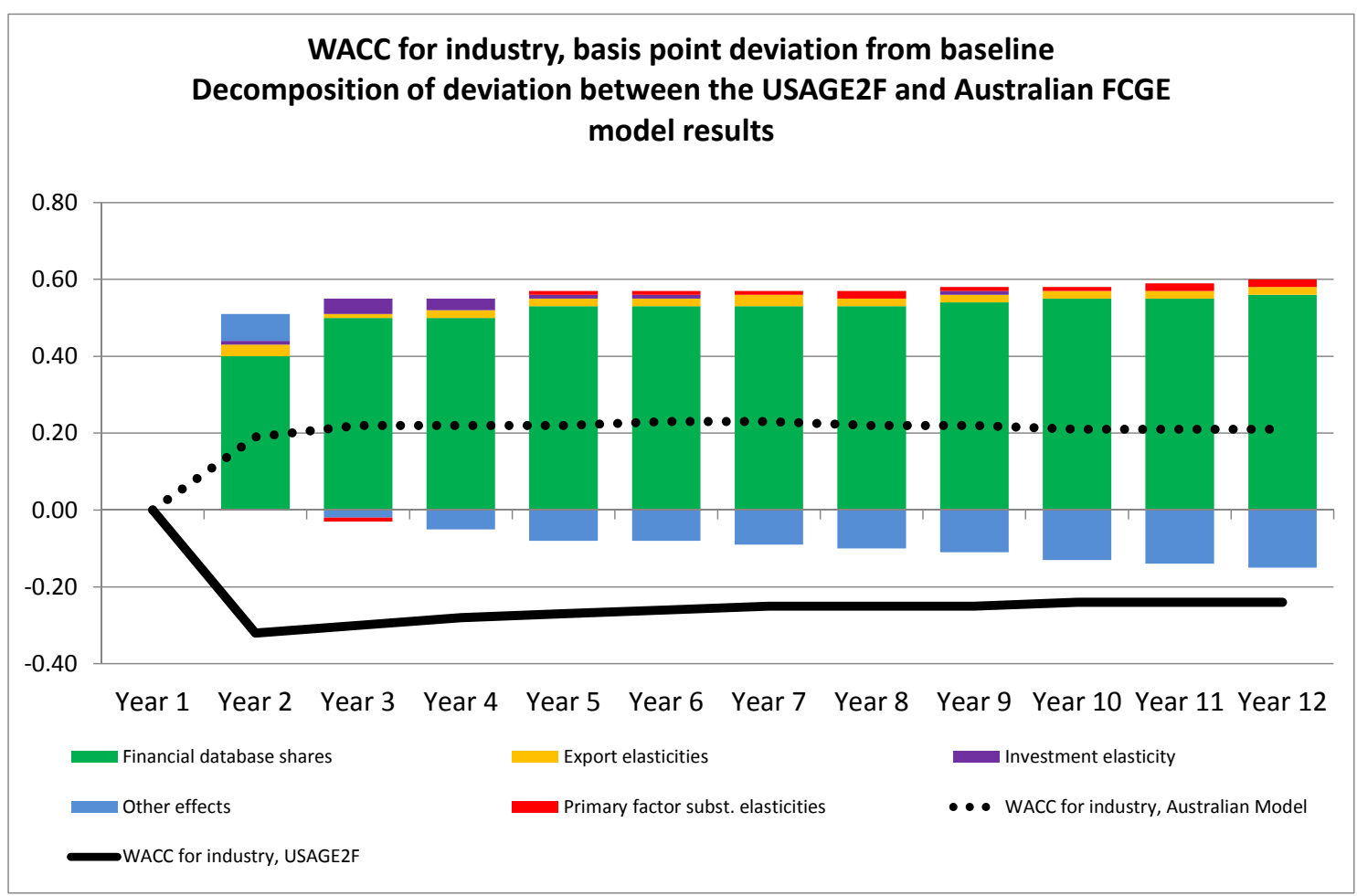

Figure 26

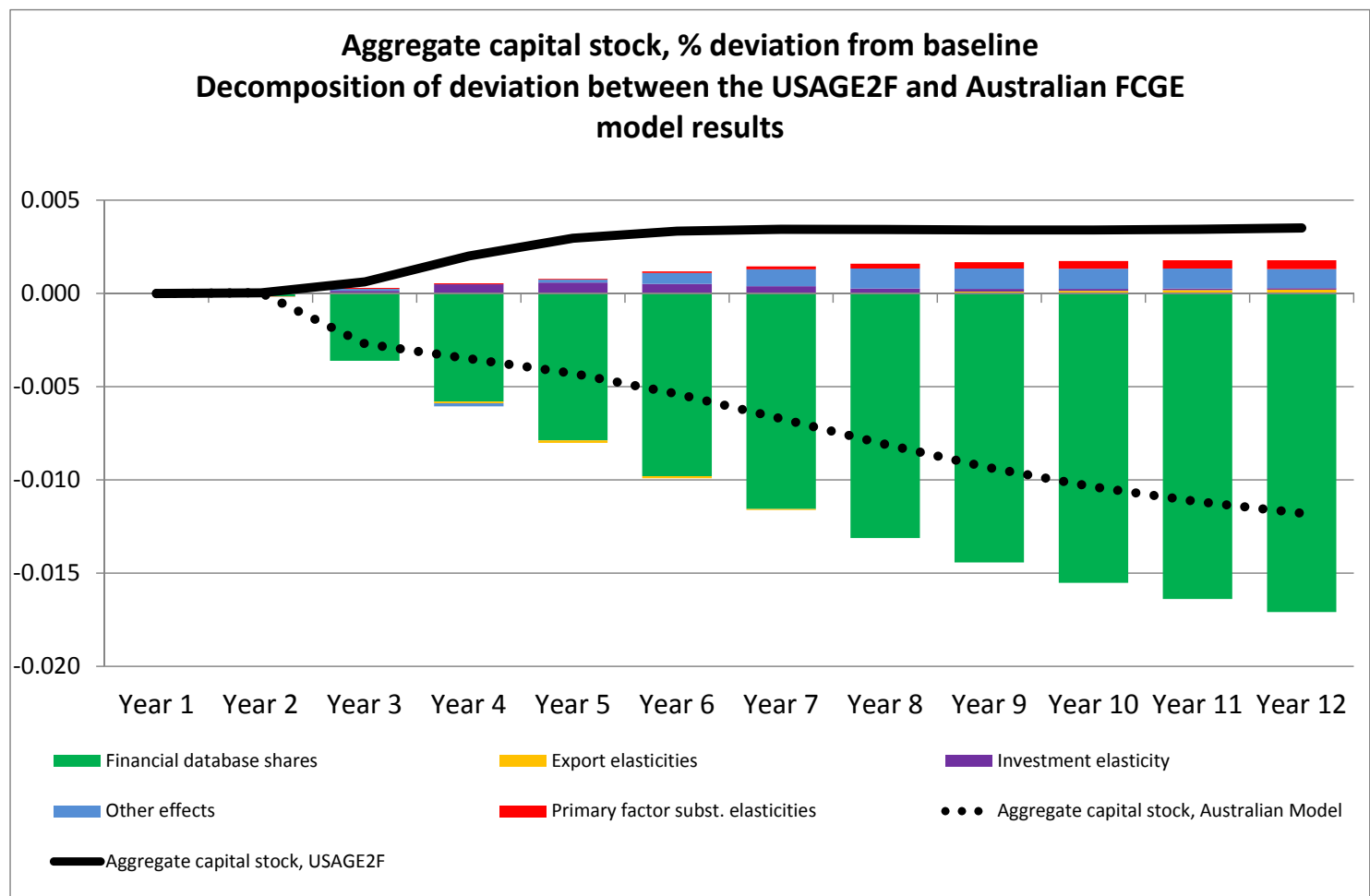


Figure 27

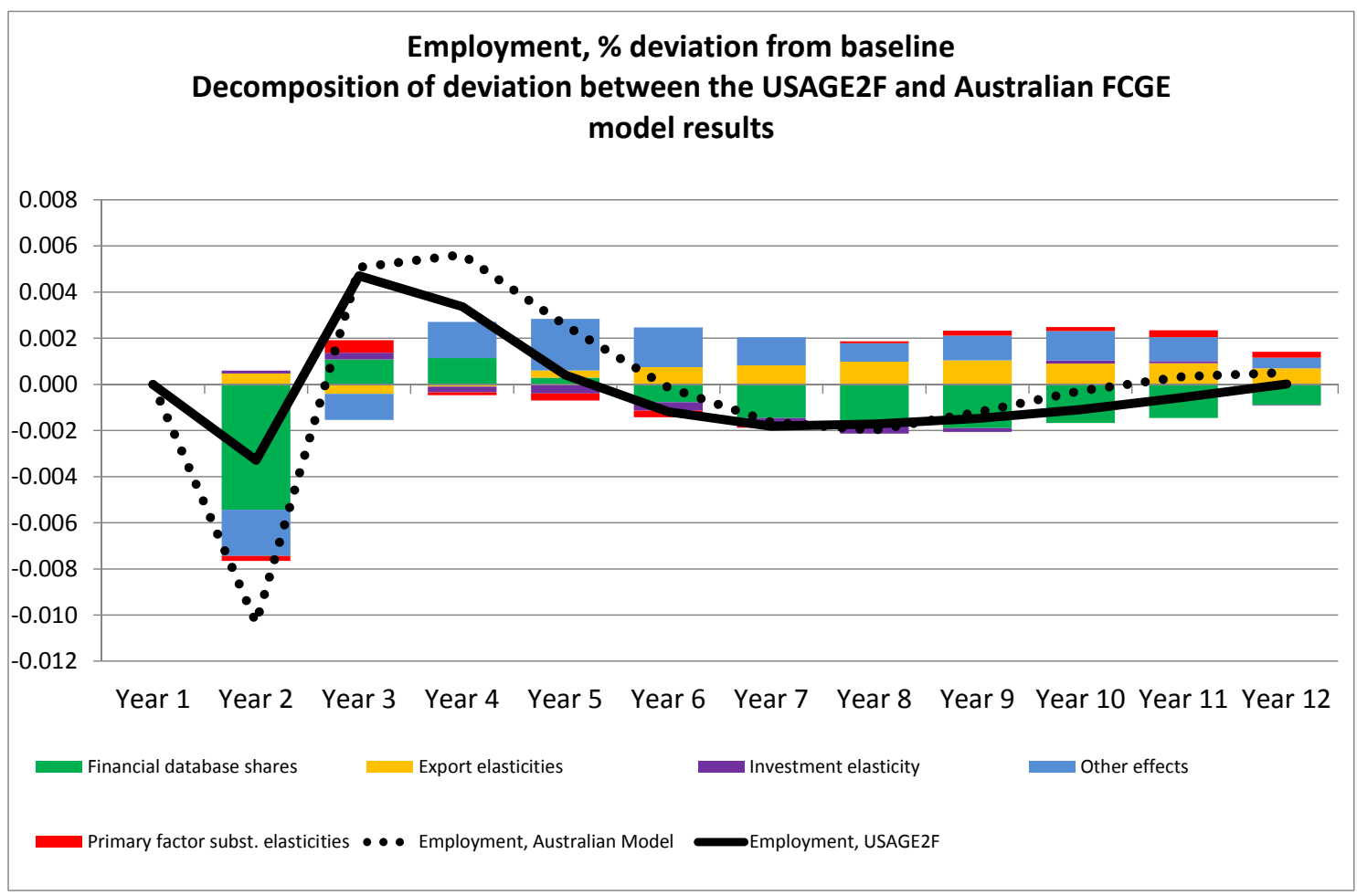

Figure 28

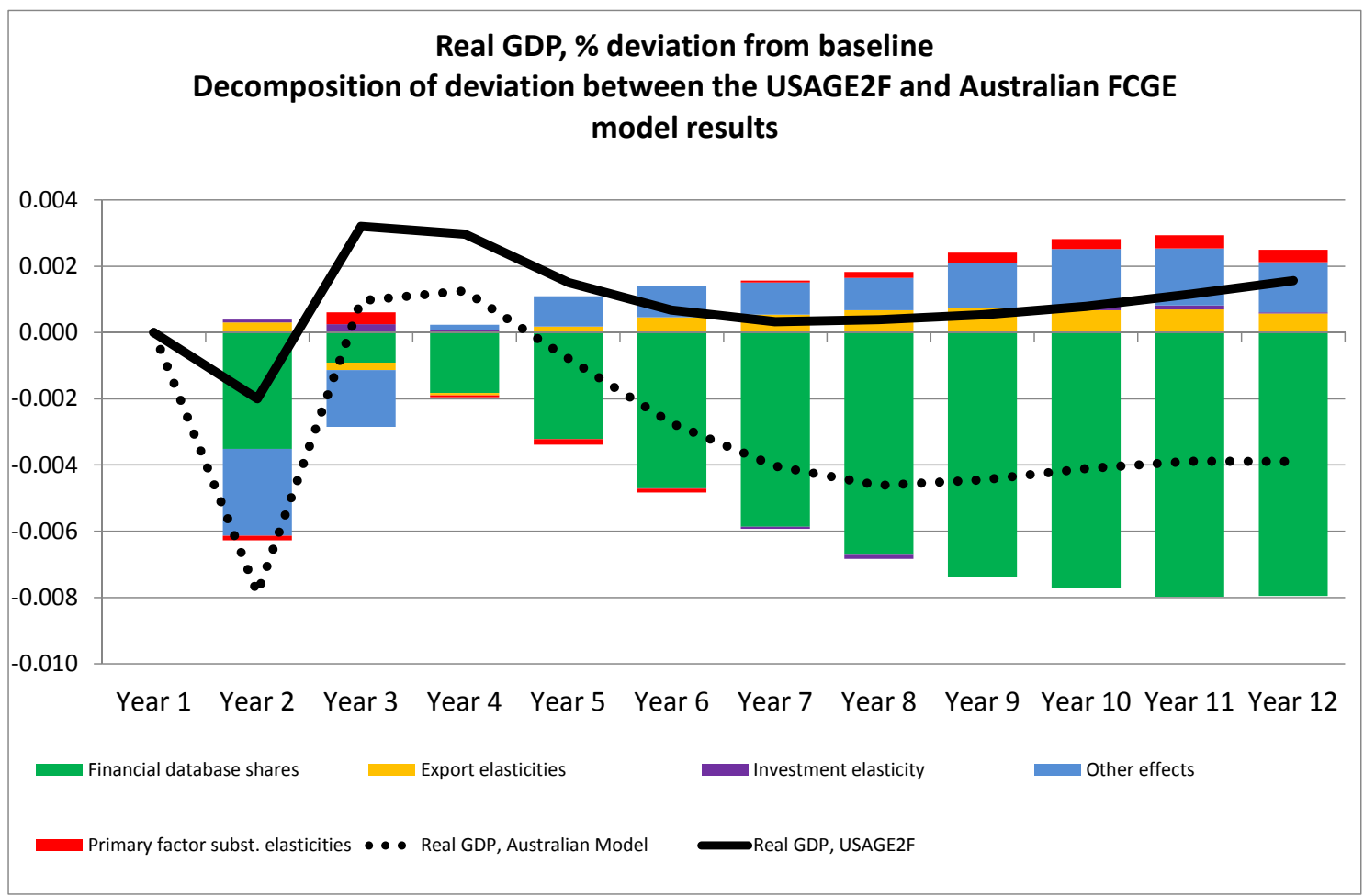

